UNIVERSIDADE DE SÃO PAULO

FACULDADE DE ZOOTECNIA E ENGENHARIA DE ALIMENTOS

PEDRO LUIZ PORFIRIO XAVIER

CARACTERIZAÇ̃̃O DE MODELO IN VITRO DE CÉLULAS INICIADORAS TUMORAIS ORIUNDAS DE NEOPLASIAS MAMÁRIAS CANINAS

\title{
PIRASSUNUNGA
}


UNIVERSIDADE DE SÃO PAULO

FACULDADE DE ZOOTECNIA E ENGENHARIA DE ALIMENTOS

PEDRO LUIZ PORFIRIO XAVIER

\section{CARACTERIZAÇÃO DE MODELO IN VITRO DE CÉLULAS INICIADORAS TUMORAIS ORIUNDAS DE NEOPLASIAS MAMÁRIAS CANINAS}

\section{Versão corrigida}

Dissertação apresentada à Faculdade de Zootecnia e Engenharia de Alimentos da Universidade de São Paulo, como parte dos requisitos para obtenção do título de mestre em Ciências, Programa de Pós-Graduação em Biociência Animal.

Área de Concentração: Biociência Animal

Orientador: Prof. Dr. Heidge Fukumasu

PIRASSUNUNGA 
Ficha catalográfica elaborada pelo

Serviço de Biblioteca e Informação, FZEA/USP, com os dados fornecidos pelo(a) autor(a)

Xavier, Pedro Luiz Porfirio
Caracterização de modelo in vitro de células
iniciadoras tumorais oriundas de neoplasias
mamárias caninas / Pedro Luiz Porfirio Xavier ;
orientador Heidge Fukumasu. - - Pirassununga, 2016.
116 f.
Dissertação (Mestrado - Programa de Pós-Graduação
em Biociencia Animal) -- Faculdade de Zootecnia e
Engenharia de Alimentos, Universidade de São Paulo.
1. Células Iniciadoras de Tumores. 2. Neoplasias
Mamárias Caninas. 3. SLug. 4. Transição Epitélio-
Hesenquimal. 5. Oncologia Comparada. I. Fukumasu,
orient. II. Título.

Permitida a cópia total ou parcial deste documento, desde que citada a fonte - o autor 


\section{FOLHA DE APROVAÇÃO}

Nome: Pedro Luiz Porfirio Xavier

Título: Caracterização de Modelo In vitro de Células Iniciadoras Tumorais oriundas de Neoplasias Mamárias Caninas

Dissertação apresentada à Faculdade de Zootecnia e Engenharia de Alimentos da Universidade de São Paulo, como parte dos requisitos para obtenção do título de mestre em Ciências, do Programa de Pós-Graduação em Biociência Animal.

Área de Concentração: Biociência Animal

Data:

Banca Examinadora

Prof. Dr.:

Instituição Julgamento:

Prof. Dr.:

Instituição Julgamento:

Prof. Dr.:

Instituição Julgamento: 
Essa e todas as minhas outras conquistas, as passadas e as que ainda estão por vir, dedico aos meus pais, João Batista Xavier e Cleuza Porfirio da Silva Xavier. Por todos os ensinamentos e por acreditarem em mim e em meus objetivos. Por me ensinarem que a vida se baseia, principalmente, em humildade, respeito, sabedoria, força de vontade e boas histórias para se contar, e que o resto, é mera consequência. 


\section{AGRADECIMENTOS}

Aos meus avós, Luiz Porfirio, Geralda Porfirio e João Rufino Xavier. Apesar de apenas dez anos de convívio, me concederam histórias felizes e marcantes, as quais poderei contar um dia aos meus filhos e netos. E a minha avó Sebastiana, que até hoje quando nos encontramos, mesmo que com pouca frequência, tem mimos e conselhos da vida para me dar. Sou muito grato por terem vocês como base da minha família.

A minha imensa família. Vocês são minha base de amor, de carinho e de felicidade. Como é bom passar quase todos os domingos com vocês, almoçando, bebendo cerveja e contando histórias. A todos os meus tios e tias, primos e primas, especialmente ao Matheus, Larissa e Lara, meus primos-irmãos. Obrigado por toda a parceria e por todos os nossos rolês juntos. É muito bom ter vocês como família! Sem vocês, nenhuma destas linhas fariam sentido.

Ao meu orientador, Professor Heidge Fukumasu, que me acolheu em seu laboratório mesmo não me conhecendo e sabendo da minha falta de experiência na área. Um exemplo de sucesso, de inteligência e de profissionalismo. Por todos os ensinamentos biológicos, pelos conselhos, pelo apoio e pela amizade, que estão me fazendo crescer muito a cada dia. Me ensinou até a fazer caipirinha! Serei eternamente grato pela oportunidade.

Ao doutor George Shigueki Yasui, meu primeiro orientador, além de grande amigo. Minha maior inspiração na carreira de pesquisador. O cara que realmente me fez gostar de ciência. Obrigado por todos os conselhos, incentivos e parceria. Serei eternamente grato a você e a todos os amigos que fiz no CEPTA.

A todos os meus professores. Desde aqueles que me ensinaram a desenhar na pré-escola, até aos professores de pós-graduação do programa de Biociência Animal da FZEA. Especialmente ao professor Ricardo Strefezzi, outro espelho de profissional, e que contribui imensamente para o avanço dos nossos projetos. Saibam que cada um de vocês tem imensa importância em minha vida. Me ensinaram o quão bom é estudar e adquirir conhecimento. Além de me fazerem querer, também, ser um educador. Serei eternamente grato a cada um de vocês.

Ao Lobos, Bruno, Felipe, Raphael e Jefferson. Os maiores amigos que a vida poderia me conceder. Vinte anos de uma amizade inabalável e extremamente valiosa em minha vida. Saibam que serei sempre grato por absolutamente tudo. Pelos nossos churrascos e pelas noites jogando FIFA, truco, poker e conversa fora. Obrigado por tudo! 
Ao V.N.A. Meus irmãos! Ary Neto, Birnão, Caim, Gui cokinha, João Pedro, Digo, Fabinho, Gû, Kahezada, Banana, Lupercim, Mathias, Mirtão, Pepito, Marcão, Pg, Sarapa, Tibúrcio, Urso, Chupeta, Pedro Pio, Piu e Ururu. Nenhuma dessas linhas faria sentido sem vocês, sem os nossos rolês, sem a pracinha... Obrigado por me tirarem do tédio e por toda a insanidade! E é claro, obrigado por me considerarem o membro mais bonito do grupo. Estarei sempre com cada um de vocês e trocaria cada um dos meus centavos pela nossa amizade. É nóis!

A todos os meus bons amigos de infância e do colégio. Obrigado por todos os bons momentos que passamos e por todos os nossos churrascos! As boas recordações que construímos sempre estarão em minha memória. Obrigado!

A todos os meus amigos filhos da PUC, especialmente ao Féla, ao Bruno Uili, a Tai, a Bru, a Nádia e a Deborinha! Sinto falta de vocês todos os dias, e gostaria que soubessem que vocês estarão sempre comigo. Obrigado por todas as festas, conversas e bagunças!

A todos os meus parceiros do LOCT! Especialmente a Nina e a Yô, que me ensinaram praticamente tudo que sei e que me ajudam em tudo, desde o primeiro dia em que cheguei. Ao Chico, pela nossa parceria, pelas besteiras que falamos e inventamos todos os dias e pelas risadas. E a Pâmelas, espelho de determinação e sucesso. Cada dia de trabalho com vocês é um aprendizado. Sou muito orgulhoso do grupo que estamos formando e sei que podemos ir muito longe, basta querermos. Obrigado por tudo!

Ao professor Flávio Meirelles, pela disponibilização de seu laboratório (LMMD) para a realização de grande parte desse projeto. E a todos os amigos que fiz ali durante esses dois anos e quatro meses. São tantos que não posso citar nome por nome aqui. Obrigado por toda a prontidão em me ajudar. Tenho ali, várias inspirações profissionais, além de excelentes amizades!

Ao professor Geovanni Dantas Cassali, por ceder os anticorpos específicos para a proteína ZEB1.

Ao professor Antônio Augusto Mendes Maia, por permitir a utilização de alguns equipamentos do seu laboratório.

A doutora Fabiana Bressan, por todo o processo de superexpressão dos genes nas células. Desde a compra dos plasmídeos, até os processos de transdução lentiviral. Muito obrigado por toda a ajuda! 
Aos doutores Juliano Coelho da Silveira e Juliano Rodrigues Sangalli, o Tchê e o Manfra. Sinônimos de inteligência, e que me ensinaram muitas coisas durante esses anos. Sempre dispostos a me ajudar com técnicas, reagentes e dúvidas frequentes.

A FZEA e ao programa de Biociência Animal por me acolherem nesse objetivo. E a CAPES, FAPESP e CNPq, pelos fomentos a esse estudo e a todos os outros em nosso laboratório.

Por fim, agradeço ao cara misterioso que projeta e comanda a vida. Obrigado por fazê-la tão complexa e tão excitante. Por me fazer curioso todos os dias e por aguçar minha vontade de viver. 
Nós jamais nascemos

"Tenho um monte de coisas para ensinar a você, no caso de não nos vermos mais. Relativas a mensagem que foi transmitida a mim, debaixo de um pinheiro na Carolina do Norte, num dia frio de inverno. Dizem que nada nunca acontece, então não se preocupe. Tudo é como um sonho. Tudo é êxtase, interiormente. Só não sabemos disso devido a nossa mente pensante. Mas na verdadeira e abençoada essência de nossa mente, sabe-se que tudo está bem eternamente e eternamente e eternamente. Feche os olhos, deixe suas mãos e terminações nervosas relaxarem. Pare de respirar por três segundos. Escute o silêncio dentro da ilusão do mundo e você lembrará a lição que esqueceu. Tudo é só uma coisa, vasta e desperta. Eu a chamo de Eternidade Dourada. Nós nunca realmente nascemos. Nós nunca realmente morremos. Não tem nada a ver com a ideia imaginária de um eu pessoal, e de outros "eus", muitos "eus" em todos os lugares. O eu, é apenas uma ideia, uma ideia de mortais. É um sonho que já terminou. Sei disso por observar as montanhas durante meses a fio. Elas nunca mostram qualquer expressão, elas são como espaço vazio. Mas o vazio do espaço, nunca vai desmoronar. Porque jamais nasceu." 


\section{RESUMO}

XAVIER, P. L. P. Caracterização de modelo in vitro de células iniciadoras tumorais oriundas de neoplasias mamárias caninas. 2016. 116 f. Dissertação (Mestrado) Faculdade de Zootecnia e Engenharia de Alimentos, Universidade de São Paulo, Pirassununga, 2016.

As neoplasias mamárias apresentam um grande desafio tanto para a medicina humana, quanto para a medicina veterinária. Esses tumores apresentam ampla heterogeneidade intertumoral e intratumoral, dificultando assim a busca por tratamentos eficazes. Recentemente, pesquisadores tem voltado sua atenção para uma população de células que apresentam características muito semelhantes as células-tronco. São as chamadas células iniciadoras de tumores (CITs). Estas são descritas como as principais responsáveis por falhas nas quimioterapias e no surgimento de recidivas tumorais, devido ao seu potencial tumorigênico, de auto-renovação e de resistência a drogas antineoplásicas. Entretanto, o estudo dessas células é limitado pelas dificuldades no isolamento e na caracterização pósenriquecimento dessas células, devido à perda do fenótipo em modelos in vitro. Sendo assim, vários estudos estão buscando maneiras alternativas de enriquecer essa população. Uma das maneiras mais utilizadas, baseia-se na indução do processo de transição epitéliomesenquimal, através da superexpressão de fatores de transcrição como SNAI1, SLUG, ZEB1 e ZEB2. Sendo assim, nós objetivamos expressar de maneira exógena os fatores de transcrição SLUG e ZEB1 em células oriundas de carcinomas mamários caninos, caracterizar seus efeitos nessas células e observar se esses fatores de transcrição seriam capazes de induzir o fenótipo de CIT. Primeiramente, quatro amostras de carcinomas mamários caninos foram analisados quanto sua morfologia e os níveis de expressão gênica de quatro fatores de transcrição associados a transição epitélio-mesenquimal: SLUG, STAT3, ZEB1 e ZEB2. Após, nós selecionamos duas dessas amostras (CC-20E e CL-28E), que apresentavam morfologia típica de células epiteliais e baixa expressão dos fatores de transcrição citados acima e expressamos de maneira exógena e de forma estável os fatores de transcrição SLUG e ZEB1, através do processo de transdução lentiviral. Entretanto, apenas a transdução com os plasmídeos contendo a região codificante de SLUG foi eficiente. Sendo assim, nós avaliamos os efeitos da expressão exógena de SLUG nas células CC-20E e CL-28E, quanto a alteração de morfologia e expressão de filamentos intermediários como citoqueratina, vimentina e actina. Além disso, nós avaliamos se a expressão exógena de SLUG poderia regular a expressão de outros genes associados a EMT, além de genes supressores de tumores, alvos de SLUG. Por fim, nós avaliamos se a expressão exógena de SLUG poderia induzir ao fenótipo de CITs, verificando se havia alteração na sensibilidade das células aos quimioterápicos doxorrubicina e paclitaxel, além de avaliar o potencial tumorigênico e de auto-renovação dessas células em cultivos de baixa aderência. A expressão exógena de SLUG nas células CC-20E e CL-28E, não induziu a alterações na morfologia epitelial das células. Entretanto, as células alteraram sua disposição em monocamada no cultivo, formando tipos de túbulos semidiferenciados, característicos do processo de EMT híbrido ou parcial. Além, disso, houve um equilíbrio entre a expressão dos filamentos intermediários de citoqueratina e vimentina nas células, além do aumento na expressão dos genes CDH1 (E-caderina) e CDH2 (N-caderina), resultado que sustentou a indução de EMT parcial. O 
processo de EMT parcial induziu maior resistência ao quimioterápico paclitaxel, além de potencializar a tumorigenecidade e a capacidade de auto-renovação das células em cultivos de baixa aderência. Sendo assim, no presente estudo, nós obtivemos um cultivo com características que mimetizam as CITs, demonstrando que os processos que induzem esse fenótipo são semelhantes tanto na espécie canina, quanto em humanos, sustentando a hipótese de que neoplasias mamárias caninas podem servir como modelo para o estudo das CITs e, consequentemente, do desenvolvimento neoplásico de tumores sólidos.

Palavras-chave: Células Iniciadoras de Tumores. Neoplasias Mamárias Caninas. SLUG. Transição Epitélio-Mesenquimal. Oncologia Comparada 


\begin{abstract}
XAVIER, P. L. P. Characterization of a in vitro model of tumor initiating cells from canine mammary neoplasms. 2016. 116 f. M.Sc. Dissertation - Faculdade de Zootecnia e Engenharia de Alimentos, Universidade de São Paulo, Pirassununga, 2016.

Mammary neoplasms present a major challenge for both human and veterinary medicine, due to intertumoral and intratumoral heterogeneity, hindering the search for effective treatments. Recently, researchers has highlighted a population of cells with features very similar to stem cells. Known as Tumor-Initiating Cells (TICs), they are described as the main responsible for chemotherapy failures and tumor recurrence, due to their tumorigenic potential, self-renewal ability and drug resistance. The study of TICs is limited mainly by their difficult isolation owing to specific markers absence, and furthermore, cells lose their phenotype when placed in vitro. Therefore, several studies are seeking for alternatives to enrich this population in regular cultures. One way is based on the epithelial-mesenchymal transition induction through of transcription factors overexpression, such as SNAI1, SLUG, ZEB1 e ZEB2. So, the aim of this study was to overexpresse the SLUG and ZEB1 transcription factors in a cell culture derived from canine mammary carcinomas, evaluate its effects and observe whether these transcription factors would be capable of inducing the TIC phenotype. First, four canine mammary carcinomas cell cultures were analyzed for their morphology and gene expression levels of four transcription factors associated with epithelial-mesenchymal transition: SLUG, STAT3, and ZEB1 ZEB2. After, we selected two samples (CC-20E and CL-28E) with typical morphology of epithelial cells and low expression of the transcription factors mentioned above. We then overexpress, stably, the transcription factors SLUG and ZEB1 by lentiviral transduction, However, only SLUG transduction was efficient. Then, we evaluated the effects of SLUG overexpression in CC-20E and CL-28E cells as the change of morphology, expression of intermediate filaments as cytokeratin, vimentin and actin. In addition, we evaluated whether SLUG overexpression could regulate the expression of other EMTassociated genes as well as tumor suppressor genes, and assessed evaluated the tumorigenic potential and self-renewal of these cells in low adherence cultures. Finally, we assessed whether SLUG overexpression could induce drug resistance through doxorubicin and paclitaxel sensivity assay. The SLUG overexpression did not induce modification in epithelial cell morphology, however, cells changed their arrangement in monolayer culture, inducing the semidifferentiated tubules, typical of hybrid or partial EMT process. In, addition, there was a balanced expression between cytokeratin and vimentin, possibly explained by an increase in $\mathrm{CDH} 1$ expression (E-cadherin) and $\mathrm{CDH} 2$ (N-cadherin) typical of partial EMT. Furthermore, the partial EMT generated cells presenting paclitaxel resistance, and enhanced the tumorigenic potential and self-renewal capacity of the cells on low adherent plates. Thus, in this study, we obtained a cell culture exhibiting features that mimics the TICs, demonstrating the mechanisms which regulate this phenotype are similar in dogs and humans, supporting the hypothesis that canine mammary carcinomas are a great model for the study of TICs and solid tumors development.
\end{abstract}

Keywords: Tumor-Initiating Cells. Canine Mammary Neoplasms. SLUG. Epithelialmesenchymal transition. Comparative Oncology. 


\section{LISTA DE FIGURAS}

Figura 1 - Processo de invasão e metástase. .24

Figura 2 - Taxas de incidência de câncer de mama em todo o mundo .27

Figura 3 - Heterogeneidade das células que constituem o ambiente tumoral .32

Figura 4 - Capacidade de auto-renovação das células iniciadoras de tumores (CITs)...36

Figura 5 - Processo de transição epitélio-mesenquimal associado à metástase .43

Figura 6 - Domínios protéicos funcionais de SLUG. .44

Figura 7 - Domínios proteicos funcionais de ZEB1 .47

Figura 8 - Sequência dos plasmídeo FUGW .57

Figura 9 - Caracterização morfológica do cultivo CC-20E. .64

Figura 10 - Caracterização morfológica do cultivo CL-28E... .65

Figura 11 - Caracterização morfológica do cultivo CB-5M .66

Figura 12 - Caracterização morfológica do cultivo CL-25M. .67

Figura 13 - Caracterização morfológica dos filamentos de actina nos cultivos celulares .68

Figura 14 - Capacidade de invasão dos cultivos celulares em insertos transwell. .71

Figura 15 - Detecção das células positivas para eGFP por microscopia de fluorescência nos cultivos controle, SLUG e ZEB1. .74

Figura 16 - Detecção das células positivas para eGFP por microscopia de fluorescência nos cultivos CC-20Eslug e CL-28Eslug após enriquecimento por citometria de fluxo. .77

Figura 17 - Caracterização morfológica dos cultivos CC-20Econtrole e CC-20Eslug..78 Figura 18 - Caracterização morfológica dos cultivos Cl-28Econtrole e CL-28Eslug....79 Figura 19 - Marcação imunocitoquímica para expressão de citoqueratina e vimentina nas células CC-20Econtrole e CC-20Eslug. .80 
Figura 20 - Marcação imunocitoquímica para expressão de citoqueratina e vimentina nos cultivos CL-28Econtrole e CL-28Eslug.....

Figura 21 - Caracterização morfológica dos filamentos de actina nos cultivos controle e com expressão exógena de SLUG.

Figura 22 - Capacidade de invasão dos cultivos controle e com expressão exógena de SLUG em insertos transwell

Figura 23 - Células controle e com expressão exógena de SLUG após um dia de cultivo em placas de baixa aderência.

Figura 24 - Formação de tumoresferas após sete dias de cultivo em placas de baixa aderência. .93

Figura 25 - Formação de tumoresferas após quatorze dias de cultivo em placas de baixa aderência. . .94

Figura 26 - Formação de tumoresferas após vinte e um dias em cultivo de baixa aderêcia. .95 


\section{LISTA DE GRÁFICOS}

Gráfico 1 - Frequência de neoplasias mamárias em cadelas.

Gráfico 2 - Expressão gênica relativa dos fatores de transcrição SLUG, STAT3, ZEB1 e ZEB2 nos cultivos celulares .70

Gráfico 3 - Capacidade de invasão dos cultivos celulares em insertos transwell .72

Gráfico 4 - Avaliação da expressão gênica de SLUG entre os cultivos transduzidos com o plasmídeo controle e os cultivos transduzidos com o plasmídeo FUGW-SLUG..... .75

Gráfico 5 - Avaliação da expressão gênica dos genes BRCA2, CDH1, HDAC1, STAT3

3 VDR entre as células CC-20Econtrole e CC-20Eslug.

Gráfico 6 - Avaliação da expressão gênica dos genes BRCA2, CDH1, CDH2, HDAC1, VDR e ZEB2 entre as células CL-28Econtrole e CL-28Eslug .86

Gráfico 7 - Avaliação da citotoxidade dos fármacos doxorrubicina e paclitaxel nas células controle e com expressão exógena de SLUG. .88

Gráfico 8 - Capacidade de invasão dos cultivos controle e com expressão exógena de SLUG em insertos transwell.

Gráfico 9 - Comparação do número e tamanho das tumoresferas formadas nos cultivos controle e com expressão exógena de SLUG. 


\section{LISTA DE TABELAS}

Tabela 1 - Classificação de neoplasias mamárias malignas baseada no perfil de expressão

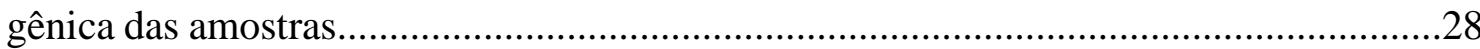

Tabela 2 - Primers específicos utilizados nas reações de PCR em tempo real.................55

Tabela 3 - Avaliação da expressão gênica de SLUG entre as células controle e com

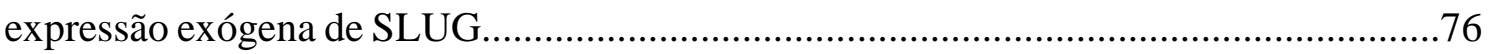

Tabela 4 - Tempo de duplicação das células controle e das células com expressão

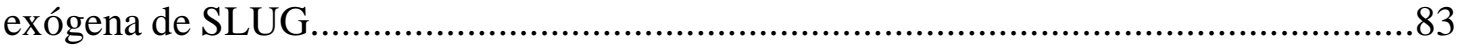

Tabela 5 - Valores de $\mathrm{IC}_{50}$ após tratamento das células controle e com expressão exógena de SLUG com doxorrubicina e paclitaxel. 


\section{LISTA DE QUADROS}

Quadro 1 - Taxas de incidência e mortalidade do câncer no mundo.. 


\section{LISTA DE ABREVIATURAS E SIGLAS}

\begin{tabular}{|c|c|}
\hline $\mathrm{ABC}$ & ATP-binding Cassete \\
\hline $\mathrm{AKT} / \mathrm{PKB}$ & Protein Kinase B \\
\hline ALDH & Aldeído Desidrogenase \\
\hline ATP & Adenosine Triphosphate \\
\hline BRCA1 & Breast Cancer 1 \\
\hline BRCA2 & Breast Cancer 2 \\
\hline cDNA & DNA complementar \\
\hline CILs & Células Iniciadoras de Leucemias \\
\hline CITs & Células Iniciadoras de Tumores \\
\hline CT & Células-Tronco \\
\hline DAPI & 4',6-diamidino-2-phenylindole \\
\hline DMSO & Dimetil Sulfóxido \\
\hline DNA & Deoxyribonucleic acid \\
\hline $\mathrm{ECM}$ & Extracellular Matrix \\
\hline EDTA & Ethylenediamine tetraacetic acid \\
\hline EGF & Epidermal Growth Factor \\
\hline EMT & Epithelial-Mesenchymal Transition \\
\hline ENPP1 & Ecto-Nucleotide Pyrophosphatase / Phosphodiesterase 1 \\
\hline epCAM & Epithelial Cell Adhesion Molecule \\
\hline ER & Estrogen Receptor \\
\hline FGF & Fibroblast Growth Factor \\
\hline GWAS & Genome-Wide Association Studies \\
\hline HCL & Ácido Clorídrico \\
\hline HDAC & Histone Deacetylase \\
\hline HER2 & Human Epidermal Growth Factor Receptor 2 \\
\hline hepaCAM & Hepatic And Glial Cell Adhesion Molecule \\
\hline IARC & International Agency for Research of Cancer \\
\hline IL3 & Interleucina 3 \\
\hline
\end{tabular}




\begin{tabular}{|c|c|}
\hline INCA & Instituto Nacional do Câncer \\
\hline KRAS & Kirsten Rat Sarcoma Viral Oncogene \\
\hline LMA & Leucemia Mielóide Aguda \\
\hline MAPK & Mitogen Activated Protein Kinases \\
\hline MDR & Multi-Drug Resistance \\
\hline miRNAs & Micro RNAs \\
\hline ORFs & Open Reading Frames \\
\hline PARP & Poly ADP Ribose Polymerase \\
\hline PBS & Phosphate-buffered saline \\
\hline PCR & Polymerase Chain Reaction \\
\hline PI3K & Phosphoinositide 3-kinase \\
\hline PR & Progesterone Receptor \\
\hline PRC2 & Polycomb Repressor Complex 2 \\
\hline PTEN & Phosphatase and tensin homolog \\
\hline RNA & Ribonucleic Acid \\
\hline SFB & Soro Fetal Bovino \\
\hline SNP & Single-Nucleotide Polymorphism \\
\hline STAT3 & Signal Transducers and Activators of Transcription 3 \\
\hline TGF $\beta$ & Transforming Growth Factor Beta \\
\hline TP53 & Tumor Protein P53 \\
\hline ZEB & Zinc Finger E-Box Binding Homeobox \\
\hline
\end{tabular}




\section{SUMÁRIO}

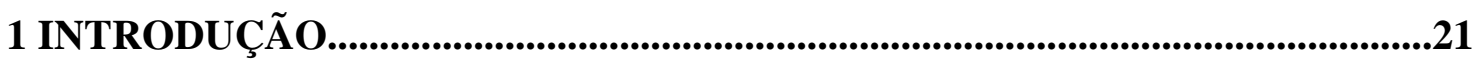

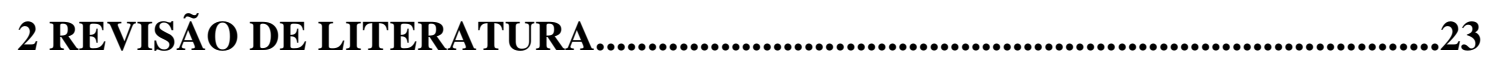

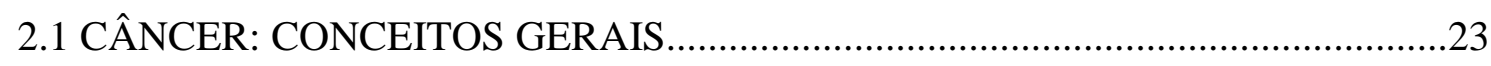

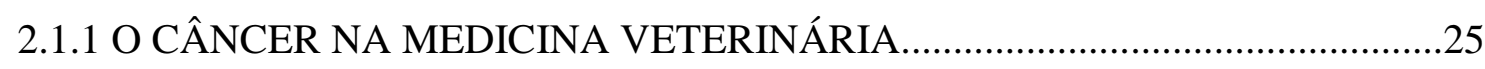

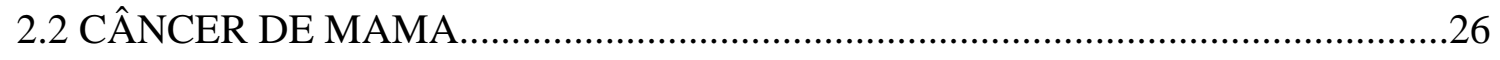

2.3 CÉLULAS INICIADORAS DE TUMORES (CITs)..............................................

2.3.1 Conceitos gerais................................................................................................................31

2.3.2 Características das CITs........................................................................................35

2.3.3 Terapias alvo às CITs.......................................................................................................37

2.3.4 Enriquecimento de populações de CITs...................................................................40

2.3.5 Processo de transição epitélio-mesenquimal (EMT) ..............................................41

2.3.6 Fator de transcrição dedo de zinco SLUG (SNAI2)...............................................44

2.3.7 Fator de transcrição dedo de zinco ZEB1...............................................................46

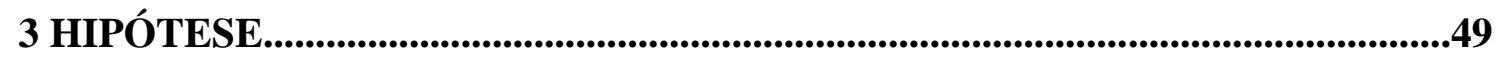

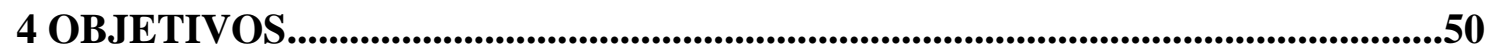

5 MATERIAL E MÉTODOS..........................................................................51

5.1 CULTIVO DE CÉlULAS ORIUNDAS DE NEOPLASIAS MAMÁRIAS CANINAS.. .51

5.2 AVALIAÇÃO DA DISPOSIÇÃO DOS FILAMENTOS DE ACTINA POR

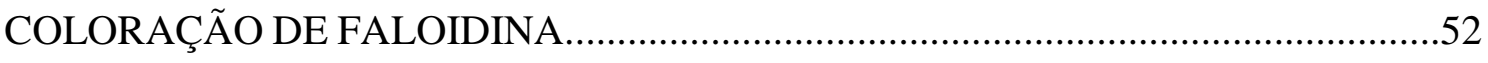

5.3 EXTRAÇÃO DE RNA E TRATAMENTO COM DNASE........................................52

5.4 TRANSCRIÇÃO REVERSA E ANÁLISES DE EXPRESSÃO GÊNICA RELATIVA POR PCR EM TEMPO REAL..............................................................54 
5.5 PREPARAÇÃO DOS PLASMÍDEOS CONTENDO AS REGIÕES

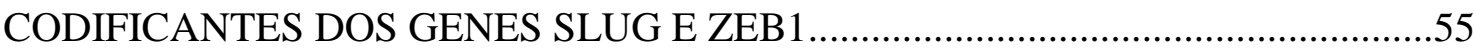

5.5.1 Preparação das bactérias competentes...................................................................55

5.5.2 Processo de transformação, clonagem e purificação dos plasmídeos .56

5.6 PROCESSO DE TRANSFECÇÃO DAS CÉLULAS 293FT E TRANSDUÇÃO ESTÁVEL DOS GENES SLUG E ZEB1 POR INFECÇÃO LENTIVIRAL..................58

5.7 ENRIQUECIMENTO DAS CÉLULAS POSITIVAS PARA EGFP ATRAVÉS DE SEPARAÇÃO POR CITOMETRIA DE FLUXO............................................................59

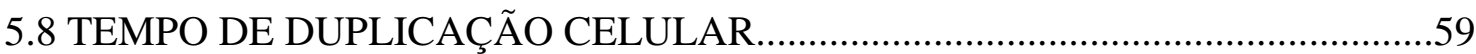

5.9 AVALIAÇÃO DA EXPRESSÃO DE CITOQUERATINA E VIMENTINA POR IMUNOFLUORESCÊNCIA. 60

5.10 AVALIAÇÃO DE CITOTOXIDADE DOS QUIMIOTERÁPICOS DOXORRUBICINA E PACLITAXEL.

5.11 ENSAIO DE INVASÃO EM INSERTOS TRANSWELL .....................................61

5.12 CULTIVO CELULAR PARA FORMAÇÃO DE TUMORESFERAS...................62

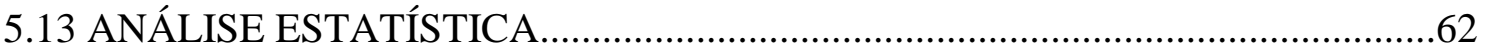

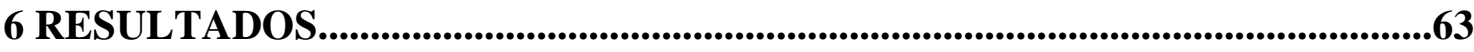

6.1 EXPERIMENTO 1: CARACTERIZAÇÃO MORFOLÓGICA DOS CULTIVOS CELULARES E AVALIAÇÃO DA EXPRESSÃO GÊNICA DE FATORES DE TRANSCRIÇÃO ASSOCIADOS A TRANSIÇÃO EPITÉLIO MESENQUIMAL

6.1.1 Caracterização morfológica por microscopia óptica.....................................63

6.1.2 Caracterização do citoesqueleto de actina........................................................67

6.1.3 Avaliação da expressão gênica de fatores de transcrição associados a transição epitélio-mesenquimal.................................................................................................................69

6.1.4 Avaliação do potencial de invasão dos cultivos celulares.....................................70 
6.2 EXPERIMENTO 2: EXPRESSÃO EXÓGENA DOS FATORES DE TRANSCRIÇÃO SLUG E ZEB1 NOS CULTIVOS DE CÉLULAS CC-20E E CL-28E E A CARACTERIZAÇÃO DE SEUS EFEITOS IN VITRO. . .72

6.2.1 Transdução lentiviral e validação da expressão exógena de SLUG e ZEB1 .73

6.2.2 Enriquecimento das células positivas para eGFP . .76

6.2.3 Caracterização morfológica das células controle e com expressão exógena de SLUG .77

6.2.4 Tempo de duplicação celular 83

6.2.5 Avaliação da expressão gênica de fatores de transcrição associados a EMT e de genes alvos de SLUG .84

6.2.6 Avaliação da sensibilidade aos fármacos doxorrubicina e paclitaxel .87

6.2.7 Avaliação do potencial de invasão das células epiteliais controle e com expressão exógena de SLUG. . .88

6.2.8 Comparação do potencial tumorgênico entre as células controle e com expressão exógena de SLUG. .090

7 DISCUSSÃO .96

7.1 SOBRE A VARIAÇÃO NA EXPRESSÃO DE FATORES DE TRANSCRIÇÃO ASSOCIADOS A EMT EM CÉLULAS ORIUNDAS DE CARCINOMAS MAMÁRIOS CANINOS E SUA CORRELAÇÃO COM O POTENCIAL DE INVASÃO. .96

7.2 SOBRE OS EFEITOS DA EXPRESSÃO EXÓGENA DE SLUG EM CÉLULAS DE CARCINOMAS MAMÁRIOS CANINOS .98

8 CONCLUSÃO 102

9 REFERÊNCIAS 103 


\section{INTRODUÇÃO}

Durante décadas, centenas de pesquisadores têm voltado seus esforços para o combate a um grupo de doenças complexas e desafiadoras, conhecidas mundialmente como câncer. Com o avanço da ciência, observou-se que a doença era ainda mais enigmática e que o interior de uma neoplasia continha uma gama de informações muito além do que se imaginava. A presença de instabilidade genômica nessas neoplasias, aliada a diversas alterações epigenéticas, são capazes de gerar uma quantidade heterogênea de células, as quais podem apresentar fenótipos distintos. Essas células, sob ação das leis darwinistas, são capazes de sustentar todas as fases do desenvolvimento tumoral, desde a iniciação passando pela promoção e progressão do tumor culminando com a formação novos tumores oriundos destes primários, conhecidos como metástases.

Dentre os possíveis fenótipos variáveis das células citadas acima, um em específico vem se destacando devido ao potencial tumorigênico associadas à características muito semelhantes às das células-tronco. As células que apresentam este fenótipo são conhecidas como células iniciadoras de tumores (CITs) ou também como células tronco cancerosas (do inglês Cancer Stem Cells, CSC). Em torno dessas células, há uma teoria, conhecida como teoria de desenvolvimento hierárquico tumoral, no qual somente as CITs seriam capazes de dar origem a um novo tumor, além de garantir as recidivas tumorais, devido à resistência que essas células apresentam contra as terapias antineoplásicas. Sendo assim, modelos de enriquecimento, identificação e caracterização dessas células, tanto para seu estudo básico, quanto aplicado, devem ser aprimorados. Uma das maneiras de se enriquecer a população de CITs, é através da indução do processo de transição epitélio-mesenquimal, regulado por uma série de fatores de transcrição como SNAI1, SLUG, ZEB1, ZEB2 e TWIST.

A utilização do modelo canino para o estudo dessas células, é quase nulo. Entretanto, devido as similaridades entre o desenvolvimento neoplásico em humanos e nesses animais, deve-se levar em conta os avanços que a oncologia comparada pode nos proporcionar, trazendo benefícios não apenas para a medicina veterinária, mas também para a medicina humana.

Desta maneira, o objetivo deste trabalho foi a caracterização dos efeitos da expressão exógena de SLUG e ZEB1 em células oriundas de carcinomas mamários, voltados, principalmente, para a padronização de um cultivo que mimetize in vitro as 
células iniciadoras de tumores (CITs), para utilizá-lo na descoberta de novas terapias com alvo específico nestas células. 


\section{REVISÃO DE LITERATURA}

\subsection{CÂNCER: CONCEITOS GERAIS}

Câncer é o nome atribuído a um grupo de mais de cem doenças que apresentam fenótipos e comportamentos distintos sendo caracterizadas principalmente por disfunções nas vias responsáveis pelo controle da proliferação, diferenciação e morte das células, culminando no desenvolvimento de massas anormais e complexas de tecidos denominadas neoplasias. Essas neoplasias desenvolvem-se de forma maligna, ou seja, com capacidade de afetar tanto a arquitetura e a função do seu tecido de origem, quanto a de tecidos adjacentes e secundários (HANAHAN; WEINBERG, 2000; KUMAR, 2011). O crescimento de tumores de forma descontínua ao tumor primário se deve a um processo conhecido como metastatização, responsável por $90 \%$ das mortes decorrentes do câncer em todo o mundo. Durante esse processo, células do tumor primário, sob certa pressão seletiva do seu microambiente, adquirem a capacidade de invadir a membrana basal e a matriz extracelular, atingindo assim os vasos sanguíneos ou linfáticos. Uma vez introduzidas ao sistema circulatório, as células malignas devem sobreviver aos mais variados obstáculos como, por exemplo, danos físicos causados por forças de compressão e células do sistema imune, e assim, disseminar-se para tecidos distantes aonde se estabelecem. A sobrevivência ao microambiente de seu novo tecido é então crucial para a formação das neoplasias secundárias, chamadas inicialmente de micrometástases (Figura 1) (VALASTYAN; WEINBERG, 2011).

Vários estudos, realizados na metade do século passado, demonstraram que o câncer desenvolve-se através de um processo de múltiplos estágios, denominado carcinogênese (BERENBLUM; SHUBIK, 1949). Tal processo ancora-se no surgimento de anormalidades genéticas e epigenéticas nas células, as quais desencadeiam, basicamente, a ativação de oncogenes e a inativação de genes supressores de tumores. Essas alterações permitem o advento de fenótipos que sustentam a proliferação dos tumores, aquisição da capacidade de invasão e disseminação metastática. São os célebres "Hallmarks of Cancer", divididos entre os hallmarks originais, propostos por Hanahan e Weinberg: 1) auto-suficiência em fatores proliferativos; 2) insensibilidade aos fatores anti-proliferativos; 3) evasão à apoptose; 4) potencial replicativo ilimitado; 5) indução de angiogênese e; 6) invasão tecidual e metástase (HANAHAN; WEINBERG, 2000), e os novos hallmarks, descritos pelos mesmos pesquisadores em 2011: 7) instabilidade genômica e mutação; 8) inflamação promotora de tumores; 9) reprogramação do 
metabolismo energético das células e; 10) evasão ao sistema imune. Além destes fatores, Hanahan e Weinberg destacaram a importância do microambiente tumoral no desenvolvimento neoplásico, discutindo sobre a ação de entidades como as células endoteliais, fibroblastos associados ao câncer, células inflamatórias do sistema imune e células-tronco e progenitoras (HANAHAN; WEINBERG, 2011).

Figura 1 - Processo de invasão e metástase

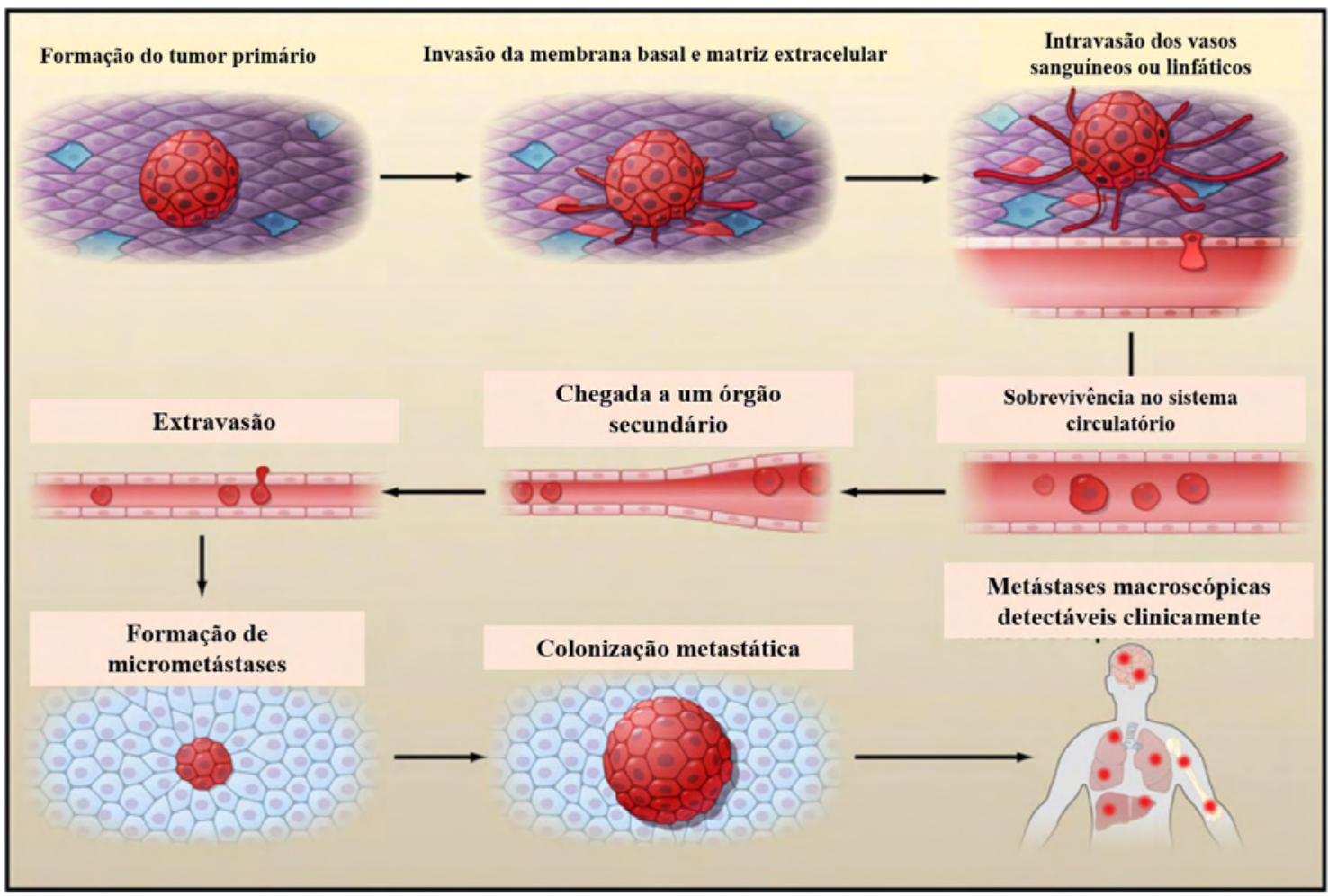

Fonte: adaptado de VALASTYAN, S.; WEINBERG, R. A. Tumor metastasis: Molecular insights and evolving paradigms. Cell, Cambridge, v. 147, n. 2, p. 275-292, 2011.

Legenda: Etapas do processo de invasão e metástase das células cancerosas, desde a formação do tumor primário, até a colonização metastática em um tecido secundário.

Mesmo após mais de meio século de intensos estudos e o avanço do conhecimento sobre diagnóstico e terapias, o câncer continua sendo um desafio para a medicina. Por ser um grupo de doenças extremamente complexo em relação ao seu desenvolvimento anatômico, fisiológico e molecular, além de apresentar alta heterogeneidade desses fatores entre seus diferentes tipos, as taxas de sucesso dos tratamentos se apresentam aquém do esperado, resultando em um alto índice de mortalidade todos os anos e em todo o mundo. Segundo dados recentes publicados pela Agência Internacional de Pesquisa do Câncer (International Agency for Research of Cancer, IARC) em 2012, foram registrados 
14,1 milhões de novos casos, 8,2 milhões de óbitos decorrentes da doença e 32,6 milhões de pessoas acometidas pelo câncer em todo o mundo (Quadro 1). O esperado, é que as taxas aumentem em 70\% nas próximas duas décadas (GLOBOCAN, 2012). No Brasil, segundo informações do Instituto Nacional do Câncer (INCA), 576 mil novos casos foram estimados para os anos de 2014/2015, representando um grave problema para a saúde pública do país. Perante essas informações, fica claro a importância de medidas de controle e prevenção contra o câncer (INCA, 2014).

Quadro 1 - Taxas de incidência e mortalidade do câncer no mundo

\begin{tabular}{|c|c|c|c|c|c|c|}
\hline \multirow[t]{2}{*}{ Número estimado (x 1000) } & \multicolumn{3}{|c|}{ Homens } & \multicolumn{3}{|c|}{ Mulheres } \\
\hline & Casos & Mortes & 5-anos prev. & Casos & Mortes & 5-anos prev. \\
\hline Mundo & 7427 & 4653 & 15362 & 6663 & 3548 & 17182 \\
\hline Regiões mais desenvolvidas & 3244 & 1592 & 8616 & 2832 & 1287 & 8297 \\
\hline \multirow[t]{3}{*}{ Regiões menos desenvolvidas } & 4184 & 3062 & 6747 & 3831 & 2261 & 8885 \\
\hline & & & & \multicolumn{3}{|c|}{ Ambos } \\
\hline & & & & Casos & Mortes & 5-anos prev. \\
\hline Mundo & & & & 14090 & 8202 & 32545 \\
\hline Regiões mais desenvolvidas & & & & 6076 & 2878 & 16913 \\
\hline Regiões menos desenvolvidas & & & & 8014 & 5323 & 15632 \\
\hline
\end{tabular}

Fonte: adaptado de GLOBOCAN, 2012. Organização mundial da saúde.

Legenda: A previsão é que o número de casos dobre nos próximos cinco anos.

\subsubsection{O CÂNCER NA MEDICINA VETERINÁRIA}

O câncer não é um problema restrito apenas a medicina humana, apresentando também um grande número de casos na medicina veterinária, principalmente na espécie canina. Nos Estados Unidos, mais de 1 milhão de casos são diagnosticados todos os anos em cães, enquanto no Reino Unido o câncer é responsável por cerca de $27 \%$ de todos os óbitos em cães de raças (ADAMS et al., 2010). Destacam-se as neoplasias de pele, seguidas pelas neoplasias mamárias (PAOLONI; KHANNA, 2008). No Brasil, pouco se sabe sobre as taxas de incidência nesses animais, principalmente pela escassez de dados e registros nas clínicas e hospitais veterinários.

A utilização do cão como modelo experimental tem sido relevante para estudos em câncer, desde seu desenvolvimento até triagem de novas estratégias terapêuticas. $O$ advento do sequenciamento do genoma canino talvez tenha sido um dos adventos mais importantes para a área da oncologia comparada. Este apresenta grande similaridade com o genoma humano, tornando os cães mais interessantes como modelos experimentais do que os roedores, por exemplo, principalmente em relação aos modelos in vitro 
(LINDBLAD-TOH et al., 2005). Além disso, assim como em humanos, os cães desenvolvem suas neoplasias de maneira espontânea, caracterizadas pelo crescimento do tumor ao longo do tempo, mesmo com a presença de um sistema imune intacto, apresentando heterogeneidade intratumoral e intertumoral, progressão metastática e desenvolvimento de resistência à drogas e recidivas (PAOLONI; KHANNA, 2008). Assim, as neoplasias caninas traduzem de forma sensata e realista o desenvolvimento tumoral em humanos, e a utilização destas pode ser fundamental no desenvolvimento coerente de terapias inovadoras para o câncer.

\section{2 - CÂNCER DE MAMA}

O câncer de mama é o segundo tipo mais comum (atrás apenas das neoplasias pulmonares) e o quinto principal responsável pelas mortes decorrentes do câncer em todo o mundo. Em mulheres, é o principal tipo e o principal responsável pelos óbitos decorrentes da doença. Em 2012, aproximadamente 1,67 milhão de casos foram diagnosticados, sendo que mais de 520 mil casos resultaram em óbito dos pacientes (Figura 2) (GLOBOCAN, 2012). No Brasil, espera-se uma estimativa de 57.960 casos para o ano de 2016, com cerca de $30 \%$ destes resultando em óbito. A preocupação com a prevenção do câncer de mama no país existe, e nos deparamos todos os anos com campanhas divulgadas por mídias impressas e audiovisuais, destinadas principalmente a importância da detecção e diagnóstico precoces da neoplasia, métodos que aumentariam as chances de cura em até 95\% (INCA, 2014).

Uma série de fatores estão associados ao desencadeamento das neoplasias mamárias e, inclusive, muitos deles são utilizados como modelos de predição para o câncer de mama. São eles: idade, idade da primeira menstruação, idade ao nascimento do primeiro filho e mutações herdáveis dos genes BRCA1 e BRCA2, ambos genes supressores de tumores responsáveis pelo reparo no DNA (FREEDMAN et al., 2005). Além disso, outras mutações genéticas comuns são encontradas em alguns pacientes, como mutações nos genes TP53 e PTEN (NJIAJU; OLOPADE, 2012). Os pacientes com câncer de mama são classificados em subgrupos, objetivando seu prognóstico e o tipo de terapia adequada. Para isso são utilizados fatores como a idade, comprometimento de linfonodos, tamanho do tumor, características histológicas e fenótipo molecular da neoplasia (SCHNITT, 2010). 
Figura 2 - Taxas de incidência de câncer de mama em todo o mundo

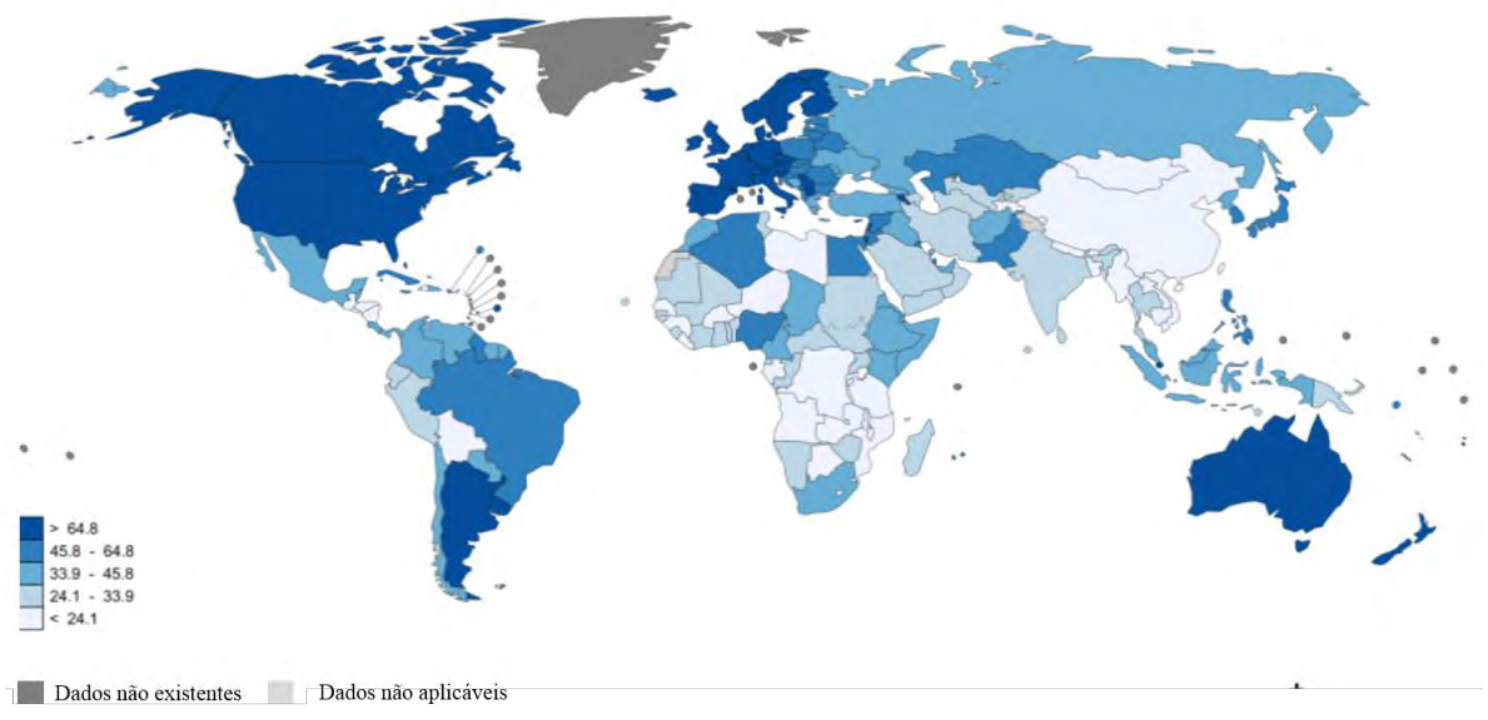

Fonte: adaptado de adaptado de GLOBOCAN, 2012.

Legenda: Taxas estimadas e ajustadas para idade padronizada, por 100.000.

As neoplasias mamárias apresentam ampla heterogeneidade intertumoral, o que pode ser observado nos diferentes tipos histológicos, resposta a terapias e variação no tempo de sobrevida das pacientes. A classificação histológica acaba sendo um pouco restrita, onde por exemplo, a maioria dos casos registrados de câncer de mama em mulheres são classificados como carcinomas ductais invasivos, porém estes casos apresentam uma grande divergência quanto seu comportamento e resposta aos tratamentos (LI; URIBE; DALING, 2005). Desta forma, houve a necessidade de novas abordagens sendo estas na maioria das vezes advindas do uso da biologia molecular que levou a grandes avanços na classificação dessas neoplasias, rastreando milhares de genes através dos sequenciamentos de nova geração e microarrays, e contribuindo para o entendimento da heterogeneidade intertumoral (ZARDAVAS et al., 2015). Levando em conta o perfil molecular, três diferentes tipos foram caracterizados quanto ao perfil de expressão de marcadores como os receptores hormonais de estrógeno (ER) e progesterona (PR) e da proteína HER2. As neoplasias positivas para os receptores hormonais ainda podem ser divididas em dois subtipos: luminal A e luminal B. O primeiro é o tipo mais comum de neoplasia mamária (50-60\% do total) e os pacientes acometidos por esse subtipo apresentam, na maioria das vezes, bom prognóstico. As neoplasias mamárias do 
subtipo luminal B representam cerca de $10-20 \%$ dos casos. São mais agressivos em comparação as neoplasias do tipo luminal A e, consequentemente, apresentam piores prognósticos. No segundo tipo de classificação estão inseridas as neoplasias positivas para a proteína HER2. Essas representam cerca de 15-20\% do total e seu prognóstico já foi considerado muito ruim. Entretanto, terapias direcionadas à HER2 apresentaram grande sucesso no tratamento de neoplasias desse tipo, melhorando o prognóstico dos pacientes. Por último, estão as neoplasias do tipo "basal-like" ou triplo negativas, referindo-se a ausência de expressão das proteínas anteriores. Essas representam cerca de 10-20\% dos casos e responsáveis pelos piores prognósticos, com grande malignidade e altas taxas de recidivas (Tabela 1) (EROLES et al., 2012).

Tabela 1 - Classificação de neoplasias mamárias malignas baseada no perfil de expressão gênica das amostras

\begin{tabular}{|c|c|c|c|}
\hline & \multicolumn{3}{|c|}{ Tipos Moleculares } \\
\hline & Luminal & HER2 & Triplo Negativas \\
\hline $\begin{array}{l}\text { Padrão de expressão de } \\
\text { genes }\end{array}$ & $\begin{array}{l}\text { Alta expressão de genes } \\
\text { hormonais RE e RP e de } \\
\text { genes associados (Luminal } \\
\text { A > Luminal B) }\end{array}$ & $\begin{array}{l}\text { Alta expressão de HER2; } \\
\text { baixa expressão de RE e } \\
\text { genes associados. }\end{array}$ & $\begin{array}{l}\text { Alta expressão de genes } \\
\text { epiteliais, como } \\
\text { citoqueratina; baixa } \\
\text { expressão de RE, RP e } \\
\text { HER2. }\end{array}$ \\
\hline Características clínicas & $\begin{array}{c}\text { Aproximadamente } 70 \% \text { dos } \\
\text { casos invasivos; positivos } \\
\text { para RE e RP; os casos de } \\
\text { luminal B tendem a } \\
\text { apresentar maior grau } \\
\text { histopatológico do que os } \\
\text { luminais A; alguns casos de } \\
\text { luminal B apresentam } \\
\text { superexpressão de HER2. }\end{array}$ & $\begin{array}{l}\text { Aproximadamente } 15 \% \text { dos } \\
\text { casos invasivos; negativas } \\
\text { para expressão de RE e RP; } \\
\text { alto grau histopatológico }\end{array}$ & $\begin{array}{c}\text { Aproximadamente } 15 \% \text { dos } \\
\text { casos invasivos; negativas } \\
\text { para a expressão de RE, RP } \\
\text { e HER } 2 \text {; disfunção de } \\
\text { BRCA1 }\end{array}$ \\
\hline $\begin{array}{l}\text { Resposta ao tratamento e } \\
\text { prognóstico }\end{array}$ & $\begin{array}{c}\text { Resposta a terapia } \\
\text { endócrina - tamoxafeno e } \\
\text { inibidores de aromatase; } \\
\text { resposta variável a } \\
\text { quimioterapia, sendo mais } \\
\text { eficientes em luminal b; } \\
\text { melhores prognósticos para } \\
\text { luminal A. }\end{array}$ & $\begin{array}{l}\text { Resposta a Trastuzumabe e } \\
\text { quimioterapia baseada em } \\
\text { antraciclinas; geralmente } \\
\text { com prognósticos ruins. }\end{array}$ & $\begin{array}{l}\text { Sem resposta a terapias } \\
\text { endócrinas ou } \\
\text { trastuzumabe; parece ser } \\
\text { sensível a quimioterápicos } \\
\text { baseados em platina e } \\
\text { inibidores de PARP; } \\
\text { prognósticos muito ruins. }\end{array}$ \\
\hline
\end{tabular}

Fonte: adaptado de SCHNITT, S. J. Classification and prognosis of invasive breast cancer: from morphology to molecular taxonomy. Modern Pathology, Baltimore, v. 23, suppl. 2, p. S60-S64, 2010.

As neoplasias mamárias representam também um grande problema na medicina veterinária. Em cães, são o segundo tipo mais frequente, atrás apenas das neoplasias de pele, e nas fêmeas, abrangem o tipo mais prevalente, correspondendo a cerca de $50 \%$ dos 
casos e apresentando taxas de incidência três vezes maiores quando comparadas às neoplasias mamárias em mulheres (Gráfico 1) (GUPTA; SOOD; UPPAL, 2012). Além disso, aproximadamente metade dos casos se apresentam de forma maligna (HELLMEN, 2005). Algumas raças como Basset, Cocker Spaniel, Poodle, Pastor Alemão assim como animais sem raça definida, parecem ser mais predispostas ao surgimento de neoplasias mamárias, apresentando maiores taxas de incidência (RUTTERMAN, 1990). Entretanto, cabe ressaltar, que nenhum estudo determinou em ampla escala, associação entre predisposição racial e o desenvolvimento de neoplasias mamárias, sendo que o fator "localização" do estudo, pode ser determinante para a análise dos resultados.

Gráfico 1 - Frequência de neoplasias mamárias em cadelas

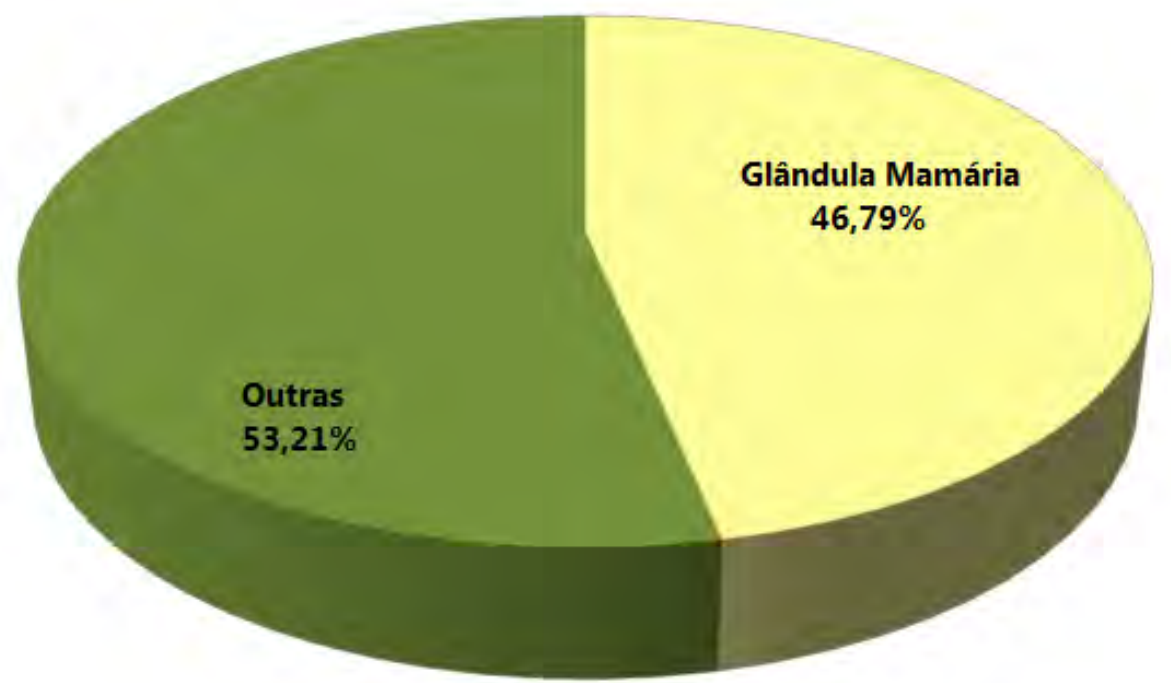

Fonte: adaptado de GUPTA, K.; SOOD, N.; UPPAL, S. Epidemiological studies on canine mammary tumour and its relevance for breast cancer studies. IOSR Journal of Pharmacy and Biological Sciences, Ghaziabad, v. 2, n. 2, p. 322-333, 2012.

A classificação histológica dessas neoplasias caninas ainda é um pouco contraditória e não consensual. As classificações mais utilizadas são as de Hampe e Misdorp (1974) e Misdorp et al. (1999) (HAMPE; MISDORP, 1974; MISDORP et al., 1999). Em 2011, Goldschimidt et al. (2011), unificaram as duas classificações e ainda incorporaram alguns outros tipos de tumores mamários, propondo assim um novo sistema de classificação, sendo que entre os tipos mais comuns de tumores benignos, destacamse os adenomas. Já em relação aos malignos, os tipos mais comuns são os carcinomas de tumores mistos e complexos (GOLDSCHMIDT et al., 2011). Cassali et al. (2007), também demonstraram que técnicas citológicas são eficientes para o diagnóstico e 
classificação das neoplasias mamárias, apresentando alta correlação com os exames histopatológicos. Além disso, seus resultados evidenciaram que existe uma grande similaridade nos achados citológicos entre neoplasias mamárias em humanos e em cães, sendo possível utilizar os mesmos critérios para a classificação desses tumores em ambas as espécies (CASSALI et al., 2007).

Como já abordado anteriormente para mulheres, as classificações histológicas em neoplasias mamárias de cães são ainda mais limitadas quanto sua utilização como fatores prognósticos e para a prescrição de terapias. Assim, trazemos novamente à tona, a importância da biologia molecular para o melhor entendimento e classificação de cada tipo de neoplasia. Como já citado, o mapeamento do genoma canino, publicado no ano de 2005, permitiu um grande avanço no entendimento dos diferentes tipos de neoplasias mamárias, incluindo ainda as similaridades apresentadas entre esses tumores em cães e humanos. Assim, uma série de estudos envolvendo técnicas como estudos de associação ampla do genoma (genome-wide association studies, GWAS) e análises do transcriptoma vem sendo realizadas, afim de desvendar as diferenças no desenvolvimento, progressão e comportamento dos mais variados tipos dessas neoplasias (LINDBLAD-TOH et al., 2005; MACHIELA; CHANOCK, 2014; RAO et al., 2008)

Mutações nos genes BRCA1 e BRCA2 estão fortemente relacionados ao desenvolvimento e malignidade dessas neoplasias em cães. Em um estudo utilizando 212 casos, foram genotipados 63 SNPs (single-nucleotide polymorphism) relacionados a genes possivelmente mutados nas neoplasias mamárias. Desses, foi constatado forte associação de um SNP no gene BRCA2 e dois SNPs no gene BRCA1, sugerindo uma relação dessas alterações com a doença (RIVERA et al., 2009). Estudos de outros genes envolvidos com a progressão de neoplasias mamárias como TGF $\beta$, hepaCAM e HER2 foram realizados, e todos eles obtiveram resultados muito similares aos que ocorrem em humanos, como a diminuição da expressão de TGFß3 e HEPACAM2 e a maior expressão de HER2 em alguns casos de neoplasias malignas (KLOPFLEISCH; SCHÜTZE; GRUBER, 2010; KLOPFLEISCH et al., 2010; RUNGSIPIPAT et al., 1999).

A utilização de microarrays para o estudo da expressão de um grande número de genes em neoplasias mamárias em cães, utilizando uma ferramenta específica para o genoma canino, foi publicada em 2008. O estudo utilizou de três linhagens de células bem caracterizadas e uma série de análises de expressão gênica foi realizada entre mais de 21.000 genes caninos. Vários genes responsáveis pelo controle da proliferação celular, 
sinalização citocinas/Rho-GTPase, integrinas e vias como WNT, foram superexpressos nessas células, enquanto alguns inibidores do ciclo celular e inibidores da via WNT foram inibidos (RAO et al., 2008). Outro trabalho, utilizou da mesma ferramenta para analisar genes diferencialmente expressos em subtipos mais malignos. Nesse trabalho, encontrouse que genes das vias MAPK, PI3K/AKT, KRAS, PTEN, WNT-beta catenin e envolvidos com reparo de DNA foram desregulados, enquanto genes de vias angiogênicas, do receptor toll, conhecido por promover transformação maligna de células epiteliais, e genes responsáveis por respostas do sistema imune e inflamatório foram superexpressos (UVA et al., 2009).

As neoplasias em glândulas mamárias em cães apresentam uma grande heterogeneidade de fenótipos histológicos, moleculares e comportamentais. Da mesma maneira, uma série de alterações moleculares podem ser observadas, principalmente, em relação às alterações na expressão de genes responsáveis pelo desenvolvimento das neoplasias. Grande parte dessas alterações encontradas em cães são similares as encontradas para humanos, o que sustenta novamente, o cão como um potencial modelo para estudos oncológicos. Entretanto, cabe a nós utilizarmos desses resultados com precaução, de maneira que os estudos realizados em cães possam ser úteis, primeiramente, para o avanço dos estudos na oncologia veterinária canina, facilitando os diagnósticos e prognósticos para esses animais.

\subsection{CÉLULAS INICIADORAS DE TUMORES (CITs)}

\subsubsection{Conceitos gerais}

Nas últimas décadas, pesquisadores têm voltado seus esforços para o estudo e entendimento da heterogeneidade intratumoral existente entre os diversos tipos de tumores (AL-HAJJ et al., 2003; LAPIDOT et al., 1994; SINGH et al., 2003). Análises histológicas e principalmente moleculares, demonstram que esses tumores apresentam uma série de fatores que determinam a heterogeneidade de suas células. O primeiro deles, baseia-se nas diferenças morfológicas entre elas. Tomando como exemplo o câncer de mama, pode-se observar a presença tanto de células epiteliais e mioepiteliais típicas, como também de células metaplásicas atípicas. As alterações epigenéticas, também podem influenciar a heterogeneidade tumoral, em função do tempo que estes tumores dispõem para acumular alterações. Por último, esses tumores também podem ser 
conduzidos por mais de uma mutação, afetando uma grande amplitude de genes e vias moleculares nas diferentes células tumorais (SMALLEY; PIGGOTT; CLARKSON, 2013; STEPHENS et al., 2012). Levando em conta essas diferentes anormalidades, constatou-se que em um mesmo tumor podem existir diferentes populações de células que, organizadas de uma maneira hierárquica, estruturam o tumor para que este possa realizar todas as fases do seu desenvolvimento, desde o processo de expansão e angiogênese, até os processos de invasão, metástase e o estabelecimento em tecidos distantes, formando os tumores secundários (Figura 3) (KRESO; DICK, 2014).

Figura 3 - Heterogeneidade das células que constituem o ambiente tumoral

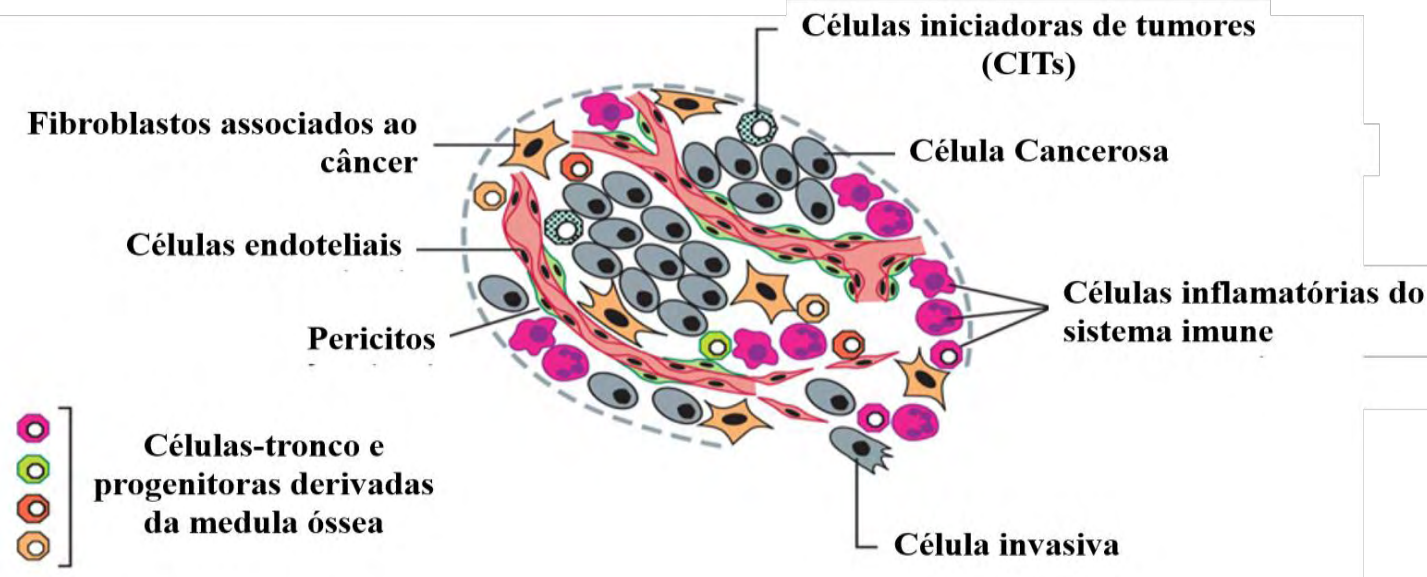

Fonte: adaptado de HANAHAN, D.; WEINBERG, R. A. Hallmarks of cancer: The next generation. Cell, Cambridge, v. 144, n. 5, p. 646-674, 2011.

Legenda: Uma mesma neoplasia é constituída por diferentes tipos de células funcionais, que com funções específicas, sustentam o desenvolvimento e a expansão tumoral.

Uma dessas populações tem recebido grande atenção da sociedade científica nos últimos anos. São as chamadas Células Iniciadoras de Tumores (CITs) que, assim como as células-tronco de um tecido normal (CTs), possuem habilidade de auto-renovação, sustentando a manutenção clonal das neoplasias (PATTABIRAMAN; WEINBERG, 2014). Além disso, por definição são células capazes de desenvolver tumores após sua injeção em camundongos imunodeficientes, demonstrando, além do potencial constante de auto-renovação, capacidade de diferenciação e resistência à múltiplas drogas (ALHAJJ et al., 2003).

Apesar de ainda apresentar muitas incógnitas, a ideia de que o câncer poderia se desenvolver a partir de células menos especializadas, começou ainda na segunda metade 
do século XX (BENNETT et al., 1978). Tais estudos, sugeriram que várias das células consideradas diferenciadas tinham origem de "células-tronco" tumorais (HAGER et al., 1981). Porém, os primeiros estudos que conseguiram determinar que os tumores poderiam se desenvolver de maneira hierárquica e que conseguiram isolaram e caracterizaram linhagens de CITs, foram realizados em amostras de pacientes com leucemia mielóide aguda (LMA). O primeiro deles foi realizado por Lapidot et al., 1994 que utilizaram dos marcadores CD34 e CD38 para isolar as primeiras células iniciadoras de tumores, chamadas de células iniciadoras de leucemias (CILs). Além disso, eles demonstraram que apenas a população que apresentava o fenótipo $\mathrm{CD} 34^{+} \mathrm{CD} 38^{-}$, eram capazes de dar origem à colônias em camundongos imunodeficientes (LAPIDOT et al., 1994). Posteriormente, Bonnet e Dick utilizaram outras amostras de LMA, injetando-as em camundongos ainda mais sensíveis (imunodeficientes e diabéticos não-obesos). Eles observaram que as CILs injetadas foram capazes de se diferenciar em blastos leucêmicos (célula leucêmica especializada), além de gerarem novas células iniciadoras, demonstrando que a LMA é organizada de maneira hierárquica, com as CILs $\mathrm{CD}^{+}{ }^{+} \mathrm{CD}^{3} 8^{-}$no topo da hierarquia (BONNET; DICK, 1997).

As primeiras evidências do isolamento e caracterização das CITs em tumores sólidos foram publicadas apenas no ano de 2003. Nesse estudo, que utilizou células provenientes de pacientes com câncer de mama, cerca de 100 células apresentando o fenótipo $\mathrm{CD} 44^{+} \mathrm{CD} 24^{-}$foram capazes de gerar tumores em camundongos, ao contrário de células com outros fenótipos, que mesmo quando injetadas em grandes quantidades não deram origem a novas formações. Além disso, os tumores gerados por essas células continuavam a conter populações heterogêneas, incluindo aquelas com maior potencial tumorigênico (AL-HAJJ et al., 2003), mostrando que os mesmos princípios hierárquicos aplicadas aos modelos de LMA, poderiam ser obtidos em tumores sólidos. CITs também foram isoladas e caracterizadas em outros tipos de tumores sólidos, como câncer de pulmão (ERAMO et al., 2008), próstata (COLLINS et al., 2005), cólon (VAIOPOULOS et al., 2012) e pâncreas (LI et al., 2007).

As CITs também vem sendo isoladas com sucesso de vários cultivos celulares oriundos de neoplasias caninas (COCOLA et al., 2009; WILSON et al., 2008). Blacking, Waterfall e Argyle (2011), por exemplo, isolaram células positivas para a proteína CD44 de linhagens celulares oriundas de osteossarcoma, melanoma, glioma e carcinomas mamários, por citometria de fluxo. Essas células apresentaram um maior potencial de 
proliferação e formação de colônias, ambos em cultivos de aderência e baixa aderência. Entretanto, as células positivas para CD44 não apresentaram maior resistência a doxorrubicina, como esperado, além de se apresentarem em maior proporção na fase G2 do ciclo celular, resultado característico de células que se proliferam mais rapidamente. Isso limitou a utilização de CD44 como um marcador para CITs em neoplasias caninas, e o associou com o potencial de proliferação das células (BLACKING; WATERFALL; ARGYLE, 2011).

Células isoladas pelo fenótipo CD44+/CD24- de quatro linhagens de adenocarcinoma mamário em cães também apresentaram uma maior capacidade de formação de esferas in vitro, teste amplamente utilizado para mimetizar o desenvolvimento tumoral in vivo. Essas esferas possuíam maior expressão de genes associados as células-tronco, como CD133, Notch3 e MDR, e também maior resistência à doxorrubicina quando comparadas as células controle. Além disso, essas células possuíram maior atividade para ALDH e quando injetadas em camundongos imunodeficientes, eram mais eficientes na formação de tumores, em relação as células negativas para CD44 e ALDH (MICHISHITA et al., 2011, MICHISHITA et al., 2012).

Populações com baixa e alta atividade de ALDH, além de positivas e negativas quanto a expressão de CD24 e CD44, também foram isoladas de quatro cultivos de carcinomas mamários mistos, utilizando citometria de fluxo e beads magnéticas. Nesse estudo, pode-se observar diferença entre a quantidade de populações positivas e negativas para CD24, CD44 e ALDH entre os cultivos. Entretanto, todos eles exibiram potencial tumorigênico in vitro, através do ensaio de formação de esferas (CORDEIRO, 2015).

Como podemos notar, os estudos de isolamento e caracterização de CITs em neoplasias caninas ainda apresentam algumas questões. Portanto, é importante que abordemos esses resultados com cautela, antes de preconizarmos biomarcadores específicos para as CITs em cães, o que já é inclusive muito discutido em neoplasias humanas.

\subsubsection{Características das CITs}

Como citado acima, as CITs exibem algumas características muito similares as CT de um tecido normal. A primeira dessas características é chamada capacidade de autorenovação. Conhecida também como "stemness", esse processo permite que, após a divisão celular, as células-tronco possam gerar uma (processo assimétrico) ou duas 
(processo simétrico) células-filhas capazes de manter a habilidade de auto-renovação e o fenótipo de CT, assegurando a manutenção e expansão clonal dessas células (Figura 4). Para ativar e manter seu potencial de auto-renovação, as CITs alteram a regulação de algumas vias moleculares, já bem caracterizadas principalmente durante o desenvolvimento embrionário de organismos multicelulares. A sinalização aumentada de vias como NOTCH, Hedgehog, WNT e BMI1 estão relacionadas a manutenção das CITs em diversos tipos de tumores sólidos, como mama (KORKAYA et al., 2009), colo de útero (VERMEULEN et al., 2010), pâncreas (LI et al., 2007) e ovário (ZHANG et al., 2008). Além dessas, vias como TGF- $\beta$ também são associadas à habilidade de autorenovação, devido a indução do processo de transição epitélio-mesenquimal (EMT), que será abordado no decorrer dessa dissertação.

Outra característica importante das CITs é a sua maior resistência a ataques citotóxicos, quando utilizados quimioterápicos. Assim como em CTs de tecidos normais, essa característica tem sido conferida, principalmente, pela maior expressão de uma família de proteínas transportadoras, dependentes de ATP, conhecidas como ABC. Essas proteínas tem a capacidade de expulsar os agentes quimioterápicos, impedindo que esses componentes se concentrem e exerçam sua função no interior das células (CHEN; HUANG; CHEN, 2013). Entre as proteínas que se destacam neste cargo, estão a ABCB1 e ABCG2 (também conhecidas como MDR1 e BCRP, respectivamente) (HIRSCHMANN-JAX et al., 2004; ZHOU et al., 2001). A ação de ABCB1 na resistência à quimioterápicos já foi observada em diversos tipos de câncer, principalmente com relação aos quimioterápicos vimblastina e paclitaxel (GRÉEN et al., 2006; WANG et al., 2005), enquanto ABCG2 mostrou influenciar tratamentos com drogas como imatinib, topotecano e metotrexato (BURGER et al., 2004; CHEN et al., 2003; SPARREBOOM et al., 2005). 
Figura 4 - Capacidade de auto-renovação das Células Iniciadoras de Tumores (CITs)

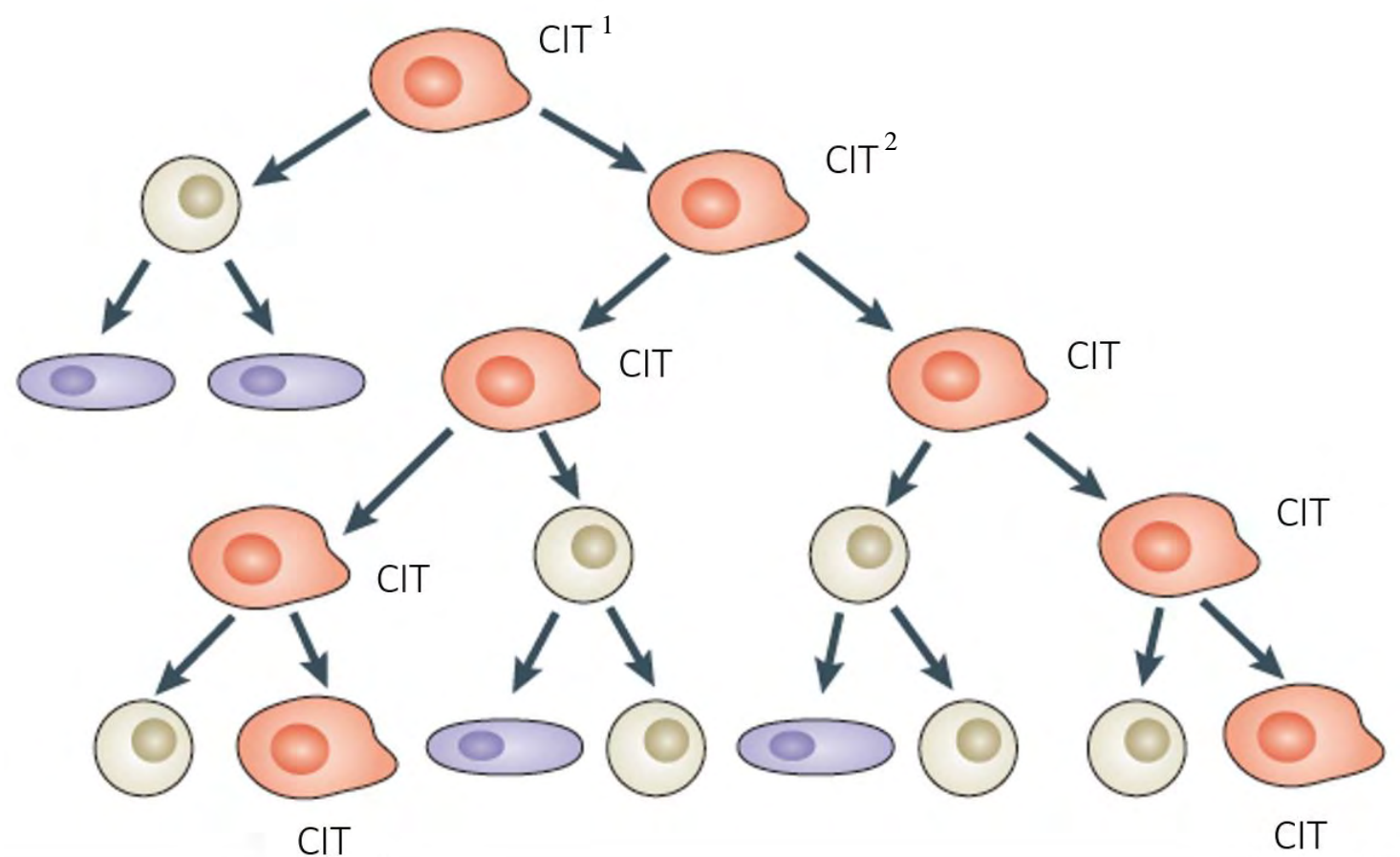

Fonte: adaptada de BECK, B.; BLANPAIN, C. Unravelling cancer stem cell potential.

Nature Reviews Cancer, London, v. 13, n. 10, p. 727-738, 2013.

Legenda: De acordo com o modelo de desenvolvimento hierárquico das neoplasias, apenas as CITs tem a habilidade de auto-renovação, ou seja, quando se dividem, dão origem a células que mantém a capacidade de "stemness", apresentando um potencial proliferativo limitado e a capacidade de diferenciação em outras células tumorais. O número 1 sobrescrito, representa um processo assimétrico de divisão, quando a uma CIT é capaz de gerar uma célula-filha com o mesmo fenótipo. Já o número 2 sobrescrito, representa uma divisão simétrica de uma CIT, gerando duas células-filhas capazes de manter o potencial de auto-renovação e o fenótipo de CIT.

Além das proteínas $\mathrm{ABC}$, outros fatores vêm sendo relacionados a maior resistência das CITs. A maior expressão da enzima aldeído desidrogenase (ALDH1), garante um poderoso sistema de detoxificação de metabólitos celulares, além da proteção contra danos oxidativos, garantindo-lhes maior resistência aos xenobióticos e muitas vezes sendo associada com piores prognósticos (GINESTIER et al., 2007). Mecanismos de reparo ao DNA, também podem estar associados à resistência dessas células. Um estudo com amostras de pacientes com glioblastoma, observou que populações de CITs exibiam respostas mais eficientes aos danos de DNA induzidas por radioterapia em 
comparação as outras células cancerosas (BAO et al., 2006).Ainda, as CITs apresentam grande resistência aos tratamentos antineoplásicos baseados em radiação, sendo que vários estudos associam essa resistência aos eficientes mecanismos de reparo ao DNA encontrados nessa população, além das baixas concentrações dos compostos químicos espécies reativas de oxigênio e dos distúrbios no ciclo celular das CITs (SKVORTSOVA et al., 2015).

Uma outra característica, também associada a maior resistência dessas células, é conhecida como estado de quiescência ou dormência celular. Levando-se em conta que, grande parte das terapias contra o câncer tem como alvo células de divisão e proliferação rápidas, a quiescência é um excelente mecanismo de proteção, fornecendo as células que são capazes de usufruir desse estado, uma válvula de escape contra a ação dos agentes quimioterápicos. Tal característica foi primeiramente notada em CITs de leucemias crônicas (HOLYOAKE et al., 1999), e, posteriormente, também em tumores sólidos como mama, melanomas e colorretal (KRESO et al., 2013; PECE et al., 2010; ROESCH et al., 2010).

As ações (muitas vezes simultâneas) desses mecanismos que capacitam habilidades como auto-renovação, pluripotência e resistência à ataques citotóxicos das CITs, explicariam os muitos casos falhos de terapias contra o câncer, desencadeando os processos metastáticos e de recidivas tumorais.

\subsubsection{Terapias alvo às CITs}

As CITs são extremamente relevantes como potenciais alvos terapêuticos. Portanto, vários estudos têm projetado experimentos com o intuito de matar ou alterar o fenótipo dessas células. Um dos estudos de destaque, foi o realizado por Gupta et al (2009), onde os pesquisadores padronizaram uma linhagem oriunda de câncer de mama silenciada para E-caderina, o que induziu o processo de transição epitélio-mesenquimal e o fenótipo de CITs nessas células. Após, uma triagem com 16.000 compostos foi realizada, na busca de substâncias que fossem específicas no combate às CITs. De todos esses compostos testados, a salinomicina, um antibiótico utilizado contra a atividade de bactérias gram-positivas, apresentou uma poderosa ação contra as CITs, reduzindo a proporção dessas células em mais de 100 vezes em relação ao paclitaxel (GUPTA et al., 2009). Uma sonda química, registrada como ML239, também foi selecionada à partir de 
uma triagem de mais de 300.000 componentes, apresentando um potencial citotóxico 20 vezes maior em CITs oriundas de câncer de mama em comparação as células controle (GERMAIN et al., 2012). A ação da metaformina, fármaco utilizado para o tratamento de diabetes do tipo II, também demonstrou bons resultados contra as CITs. Nesse estudo, houve uma grande redução da população de CITs oriundas de neoplasias mamárias de cadelas, através da inibição da expressão de um gene chamado ENPP1 (TAKAHASHI et al., 2015).

Além dessas substâncias, vários tipos de terapias vêm sendo traçadas para atingir vias específicas das CITs. Uma das estratégias, alveja-se nas proteínas de membrana características dessas células. Algumas dessas proteínas podem ser utilizadas para que a terapia seja direcionada, especificamente, as CITs. Em casos de leucemia mielóide aguda (LMA), por exemplo, a um aumento na expressão do CD123, uma subunidade do receptor de interleucina-3 (IL3). Portanto, foi desenvolvido um anticorpo chamado 7G3 afim de neutralizar esse marcador, o que levou a redução da população de CITs e a um melhor prognóstico quando testada em camundongos (JIN et al., 2009). Outro exemplo, é a utilização da proteína CD44 em CITs oriundas de câncer de mama. Anticorpos anti-CD44 foram conjugados a nanobastões de ouro, que quando expostos a luz infravermelha, aquecem as células marcadas, destruindo-as (LEE et al, 2012). Outros marcadores, como o CD133, apresentam alta expressão em diferentes CITs, como em neoplasias pulmonares, de mama e glioblastomas, podendo ser conjugados a diferentes estratégias terapêuticas (WANG et al., 2011).

Como citado anteriormente, as CITs exibem alta expressão de proteínas da família $\mathrm{ABC}$, o que lhes garante maior efluxo de drogas e consequentemente maior resistência as terapias convencionais. Portanto, estratégias que objetivam a inibição dessas proteínas podem ser eficientes no tratamento específico das CITs. Inibidores como MS-209, VX710 e taquiridar, muitas vezes em combinação com outros quimioterápicos como docetaxel, paclitaxel e doxorrubicina já são utilizados na tentativa de superar a resistência às drogas, podendo, consequentemente, apresentarem bons resultados contra as CITs (SAEKI et al., 2007; PATIL et al., 2009). As vias responsáveis pela manutenção da habilidade de auto-renovação das CITs também vêm sendo utilizadas no combate a essas células. Produção de anticorpos monoclonais contra a via de sinalização Notch, reduziu a população de célula CD44+/CD24- em neoplasias mamárias, por exemplo (MCGOWAN et al., 2011). Substâncias inibidoras das vias WNT e Hedgehog também 
estão sendo testadas separadamente e concomitantes com outras substâncias, apresentando bons resultados. A ciclopamina, um inibidor da via Hedgehog, em sinergismo com a gencitabina, restringiu a população de células $\mathrm{ALDH}^{\text {hi }}$ em neoplasias no pâncreas, enquanto a ciclopamina junto a doses de temozolomida, teve o mesmo efeito em glioblastomas (FELDMANN et al., 2007; ULASOV et al., 2011).

Por último, destaca-se o desenvolvimento de possíveis terapias epigenéticas no combate as CITs, objetivando não só a morte dessas células, como também uma possível reversão do fenótipo de CITs, tornando-as mais susceptíveis aos quimioterápicos convencionais. Alguns inibidores de metiltransferases, tais como azacitidina e decitabina, mostraram suprimir o desenvolvimento de CITs em neoplasias hematológicas, por exemplo (TSAI et al., 2012). Outro estudo, desenvolvido por Roulois et al. (2015) observou que baixas doses 5-AZA-CdR, podem destruir as CITs em câncer colorretal, através da indução da expressão de RNAs de dupla fita e de desregulação da via MDA5/MAVS/IRF7 (ROULOIS et al., 2015). Inibidores de acetilases de histonas (HDAC) mostraram efeitos dose-dependente na diferenciação do fenótipo de CITs em neoplasias mamárias e de cabeça e pescoço, por exemplo (CHIKAMATSU et al., 2013; SALVADOR et al., 2013). A regulação de miRNAs também parece ser fundamental na resistência às drogas. A maior expressão do miR-22, por exemplo, promove células com habilidades de auto-renovação em leucemias, enquanto o miR-27b parece inibir as características de CITs em neoplasias mamárias (SONG, 2013; TAKAHASHI et al., 2015). Sendo assim, tratamentos que envolvam a regulação dessas moléculas poderiam ser de extrema eficiência contra as CITs (SONG et al., 2013)

Como podemos notar, a eficiência das drogas utilizadas no combate ao câncer é muitas vezes afetada por células que desenvolvem mecanismos de proteção mais complexos e elaborados, apresentando, consequentemente, maior resistência. Assim, uma série de estratégias vêm sendo traçadas para tornar o tratamento contra essas células mais específico e eficiente. Tais esforços são de extrema valia, podendo inclusive melhorar o prognóstico dos pacientes através da redução das recidivas tumorais. Além disso, a descoberta de como deter essas células, seria fundamental para o entendimento das fases de iniciação e desenvolvimento do câncer. 


\subsubsection{Enriquecimento de populações de CITs}

As CITs possuem alguns marcadores que podem ser utilizados para seu isolamento e enriquecimento perante outras populações tumorais. A utilização de marcadores de membrana como, por exemplo, o CD133, CD44 e CD24, utilizando técnicas de imunofenotipagem é uma das principais metodologias utilizadas. A glicoproteína CD133, envolvida principalmente na organização da membrana plasmática, é amplamente utilizado para a detecção e isolamento de CITs em tumores pulmonares, cerebrais e pancreáticos (ERAMO et al., 2008; HERMANN et al., 2007; SINGH et al., 2003). Já as glicoproteínas de membrana CD44 e CD24 são muito utilizadas para a detecção e isolamento de CITs em neoplasias mamárias. Da mesma maneira, populações $\mathrm{EpCAM}^{+} / \mathrm{CD} 49^{+}$também já demonstraram selecionar populações enriquecidas de CITs em neoplasias mamárias (LIM et al., 2009).

Além dos marcadores de membrana, outras proteínas vêm sendo utilizadas para o enriquecimento de CITs. É o caso da aldeído desidrogenase 1 (ALDH1), uma enzima responsável por proteger as células de danos oxidativos, que já foi descrita na utilização para o enriquecimento de CITs em neoplasias colorretais, mamárias e leucemias (CHEUNG et al., 2007; DEBEB; WOODWARD, 2014; HUANG et al., 2010; TELL; HORVATH, 2014). Outra técnica utilizada para o enriquecimento de CITs é chamada de Side Population (SP). Essa se baseia na propriedade que as CITs possuem de apresentar menor intensidade fluorescente nas emissões em azul e vermelho do Hoechst33342 em relação às outras células neoplásicas situando-se no canto inferior esquerdo quando da análise pelo citômetro de fluxo (daí a razão do nome side population). Esta propriedade é relacionada à maior expressão de genes MDR nestas células, principalmente o gene ATP-binding cassette, sub-family G, member 2 (ABCG2) (GOODELL et al., 1996).

Apesar do sucesso no enriquecimento de CITs em vários tipos de tumores sólidos, utilizando as estratégias citadas acima, é necessário cautela quanto a utilização dos mesmos. Isso porque alguns deles podem ser expressos também em outros tipos de células, como as próprias células-tronco de tecidos normais. O CD133, por exemplo, pode ser encontrado em células-tronco e progenitoras de tecidos como fígado, rim e próstata (AM ESCH et al., 2005; BUSSOLATI et al., 2005; RICHARDSON et al., 2004). A utilização do fenótipo CD44+CD24-, para o isolamento de CITs em neoplasias mamárias 
também apresenta controvérsias. Apesar de ser amplamente utilizado, já foi demonstrado que em alguns tipos de tumores de mama, as CITs não respondem para esse tipo de marcador (AL-HAJJ et al., 2003). Problemas pós-enriquecimento das CITs também são frequentes, impossibilitando o estudo tanto básico quanto aplicado, no tocante à terapias, para essas células. Como a população de CITs geralmente representa uma fração mínima da massa tumoral, é necessário que as células isoladas sejam replicadas de maneira in vitro. Todavia, essa etapa muitas vezes não é possível de ser realizada, já que as células enriquecidas perdem rapidamente seu fenótipo em condições de cultivo celular (FILLMORE; KUPERWASSER, 2008). Assim, estudos começaram a ser realizados a fim de padronizar um modelo estável de CITs ou de células que mimetizassem o fenótipo de CITs.

Um dos métodos utilizados para o enriquecimento de CITs em populações in vitro, baseia-se na indução do processo de transição epitélio-mesenquimal (EMT) (MANI et al., 2008). Desde então, uma série de estudos objetivaram a indução desse processo. Gupta e colaboradores, por exemplo, silenciaram apenas a expressão do gene e-caderina, resultando no enriquecimento de células CD44+/CD24- que apresentavam um aumento na resistência à quimioterápicos em comparação com as células controle (GUPTA et al., 2009). Outros trabalhos realizaram o controle e indução do processo de EMT através da superexpressão de fatores de transcrição como TWIST, SNAI1/2 e ZEB1/2 (VESUNA et al., 2009; WELLNER et al., 2009; ZHU et al., 2012).

\subsubsection{Processo de transição epitélio-mesenquimal (EMT)}

Transição epitélio-mesenquimal (EMT) é um processo biológico no qual células epiteliais polarizadas e não-móveis sofrem uma desregulação na expressão de suas proteínas de adesão e junção, adquirindo características de células mesenquimais e nãopolarizadas. O processo desencadeia uma série de alterações no fenótipo dessas células, como a reorganização do seu citoesqueleto e a reprogramação de algumas vias moleculares, aumentando a motilidade e a capacidade de invasão dessas células (KALLURI; WEINBERG, 2009). O processo de EMT pode ser classificado em três diferentes tipos. O processo do tipo I está relacionado ao desenvolvimento embrionário dos animais vertebrados e invertebrados, especialmente durante os eventos de gastrulação e formação da crista neural (HEISENBERG; SOLNICA-KREZEL, 2008; SAUKA- 
SPENGLER; BRONNER-FRASER, 2008). Tal evento também é observado durante alguns processos da vida adulta, como por exemplo, os processos de cicatrização de ferimentos e de cicatrizações pós-ovulatórias em cada ciclo menstrual das mulheres (AHMED, 2006; YAN et al., 2010). Esses processos podem ser englobados nos eventos de EMT do tipo II.

Apesar de ser fundamental para o desenvolvimento e regeneração de alguns tecidos, o processo de EMT também pode ser considerado patológico em algumas circunstâncias, sendo considerados EMT do tipo III. O surgimento de fibroses teciduais em alguns órgãos é uma delas. Nesses casos, EMT é responsável pela transformação de células epiteliais ou fibroblastos em miofibroblastos, que excretam quantidades excessivas de colágeno comprometendo a função dos órgãos atingidos (THIERY et al., 2009), como em casos de fibroses pulmonares, renais e cardíacas (CAREW; WANG; KANTHARIDIS，2012; CHAPMAN，2011; KRENNING; ZEISBERG; KALLURI, 2010).

O processo de EMT também está intimamente envolvido com o câncer, sendo de extrema importância para a progressão metastática das células (Figura 5). Entre os eventos impulsionados pela EMT no processo metastático, está a perda de proteínas importantes pelo estado de adesão das células, como E-caderina, ocludinas, desmossomos e citoqueratina, além do aumento da expressão de proteínas envolvidas na maior mobilidade e capacidade de invasão das células, como $\mathrm{N}$-caderina, vimentina e metaloproteinases (POLYAK; WEINBERG, 2009). A repressão e ativação transcricional dessas proteínas é mediada por alguns fatores de transcrição como TWIST, SNAI1, SLUG, ZEB1 e ZEB2. Essas proteínas são amplamente expressas em diversos tipos de câncer e muitas vezes correlacionadas à piores prognósticos (THIERY, 2002).

Não só o processo completo de EMT está associado ao câncer. Uma outra vertente do processo, conhecida como transição epitélio-mesenquimal parcial ou híbrida, também vem sendo correlacionada aos processos de metástase e malignidade (HUBER; KRAUT; BEUG, 2005). Durante esse processo, diferente da EMT completa, as células que o sofrem são capazes de manter alguns de seus marcadores epiteliais, além de adquirir alguns marcadores mesenquimais, permitindo um potencial migratório e invasivo das células (JOLLY, 2015). Esse processo também está associado, principalmente, aos eventos de tubulogênese, no desenvolvimento de glândulas mamárias, e na cicatrização de tecidos epiteliais (LAMOUILLE; XU; DERYNCK, 2014; LEROY; MOSTOV, 2007). 
Figura 5 - Processo de transição epitélio-mesenquimal associado a metástase

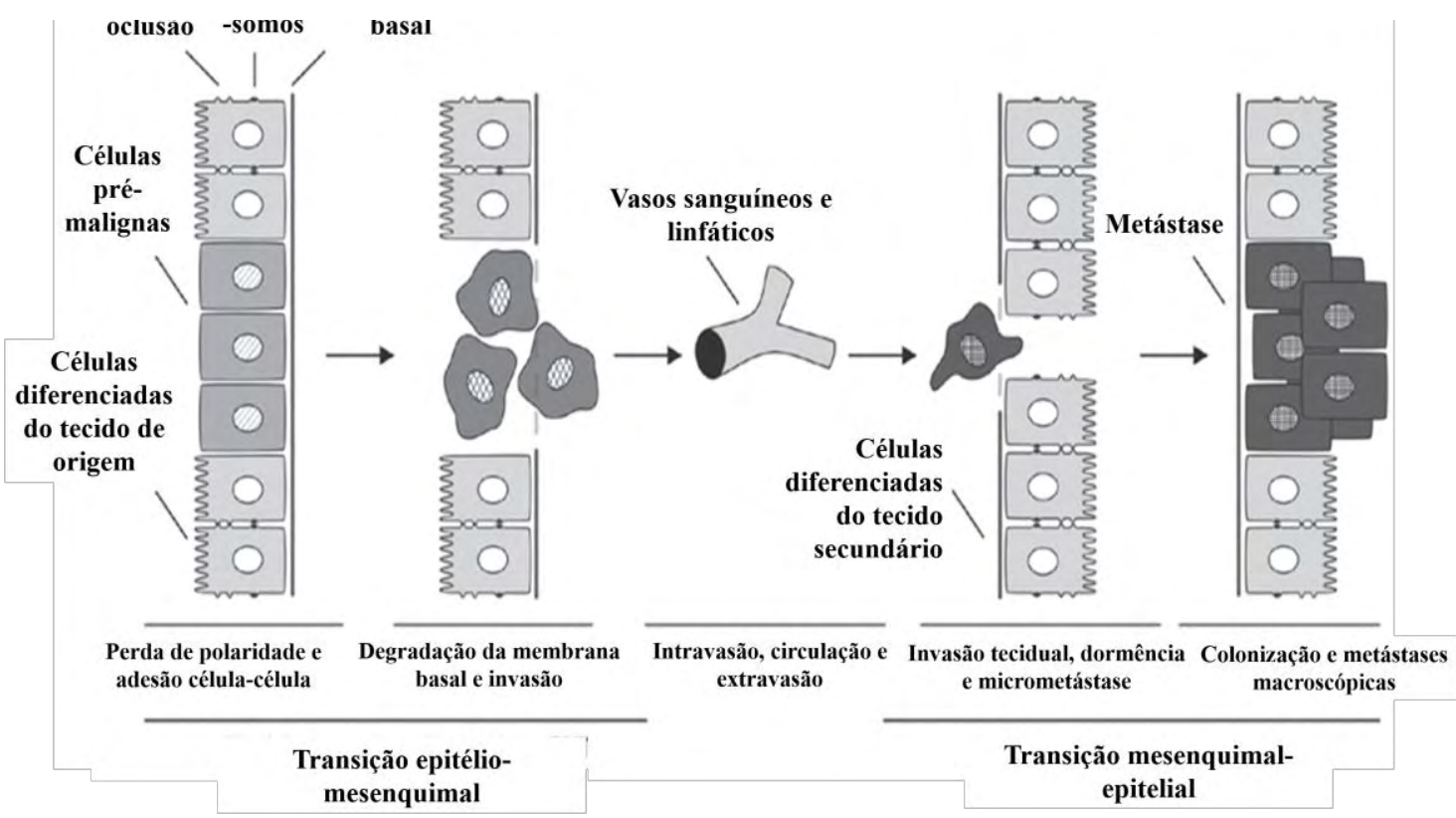

Fonte: adaptado de KIESSLICH, T.; PICHLER, M.; NEUREITER, D. Epigenetic controlo of epithelial-mesenchymal-transition in human cancer (review). Molecular and Clinical Oncology, London, v. 1. p 3-11, 2013.

Legenda: A transição epitélio-mesenquimal é fundamental para o processo de invasão e metástase das células cancerosas. Ele é responsável por processos como a degradação das proteínas de adesão e a perda da polaridade celular, o que permite a intravasão das células cancerosas nos vasos e disseminação para os tecidos secundários. O processo de transição mesenquimal-epitelial, é o responsável por permitir a colonização das células no tecido secundário.

O processo de EMT também está associado com a obtenção do fenótipo de CITs tanto em células neoplásicas quanto em células normais. Vários estudos demonstraram que a indução desse processo promove a aquisição de características de CITs e em vários tipos de tumores sólidos como mama (MOREL et al., 2008), pâncreas (WANG et al., 2009b), colorretal (BRABLETZ et al., 2005) e fígado (WANG et al., 2015). Durante a ativação do processo de EMT, uma série de genes, até então silenciados, passam a ser expressos, afim de regular os eventos que proporcionam o fenômeno de "stemness". A seguir, abordaremos de maneira mais profunda dois desses fatores de transcrição, fundamentais no desenvolvimento dessa dissertação. 


\subsubsection{Fator de transcrição dedo de zinco SLUG (SNAI2)}

SLUG, também conhecido como SNAI2, é um membro da família SNAIL de proteínas dedo de zinco. Essas proteínas são constituídas de uma região C-terminal extremamente conservada entre as espécies e contém cerca de quatro à seis dedos de zinco, regiões capazes de se ligar à sequências repetitivas e específicas do DNA (motivos) (Figura 6) (NIETO, 2002). O sítio de ligação desses fatores de transcrição baseia-se na sequência 5'-CAGGTG-3'e, quando ligados a essa região agem como repressores transcricionais (HEMAVATHY; ASHRAF; IP, 2000; MAUHIN et al., 1993). Porém, apenas a ligação desses domínios as regiões promotoras de genes alvos não é capaz de realizar a atividade repressora. Esses fatores de transcrição dependem de mais dois diferentes motivos, conhecidos como domínio SNAG/Gfi e CtBP (GRIMES et al., 1996; NIBU et al., 1998). Esses processos de repressão são então capazes de desencadear o processo de EMT, que como já citado no tópico acima, é fundamental durante a formação da mesoderme e da crista neural, ao decorrer do desenvolvimento dos animais vertebrados e invertebrados.

Figura 6 - Domínios protéicos funcionais de SLUG

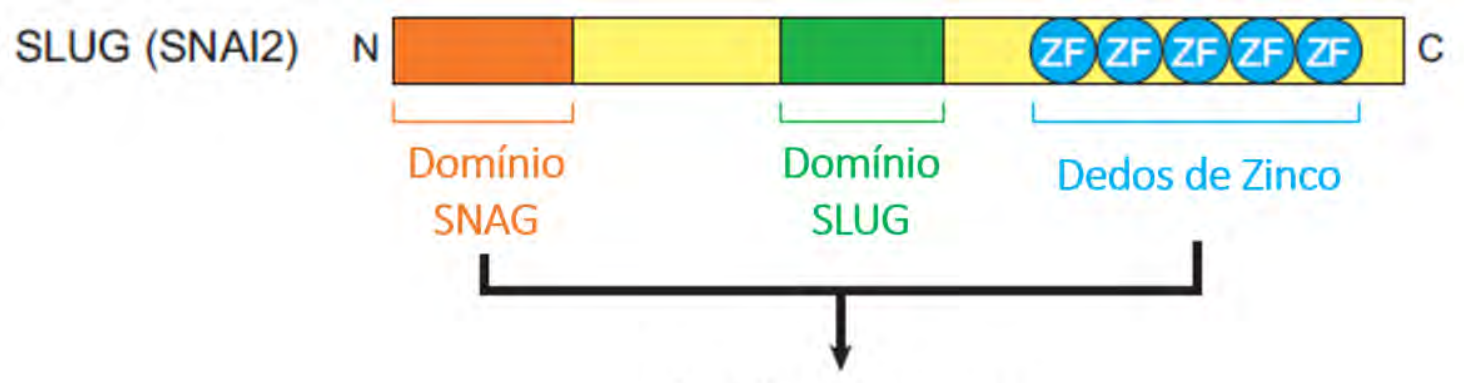

Atividade repressora

Fonte: adaptado de COBALEDA, C. et al. Function of the zinc-finger transcription factor SNAI2 in cancer and development. Annual Review of Genetics, Palo Alto, v. 41, p. 41-61, 2007.

Legenda: SLUG contém um domínio SNAG N-terminal e domínios dedos de zinco Cterminal, responsáveis pela sua atividade repressora de genes.

SLUG (ou SNAI2) foi primeiramente identificado no desenvolvimento de embriões de galinhas. Estudos posteriores demonstraram então, ampla homologia de estrutura e função desse fator de transcrição em camundongos e humanos, sendo sempre fundamental no desenvolvimento da mesoderme e da crista neural nos embriões 
(COBALEDA et al., 2007). Entretanto, nos dias atuais, esse fator de transcrição é estudado devido a sua ação na progressão de algumas doenças, como a síndrome de Waardenburg e piebaldismo (ambas envolvendo alterações em melanócitos), doenças no coração e um tipo de anemia, conhecida como anemia de Diamond-Blackfan (PÉREZLOSADA et al., 2002; SÁNCHEZ-MARTÍN et al., 2002).

O papel de SLUG no câncer também é muito estudado, principalmente pela sua correlação com a perda de proteínas epiteliais, especialmente a E-caderina, durante os eventos metastáticos. Tal papel vem sendo relatado em uma grande diversidade de cânceres, como carcinomas pulmonares (SHIH; YANG, 2011), de mama (CÔME et al., 2006), pâncreas (LI et al., 2014) e próstata (UYGUR; WU, 2011). SLUG vem também sendo relacionado a outros processos que colaboram para o desenvolvimento neoplásico. Mutações clássicas no gene TP53 em câncer de pulmão de células não pequenas, por exemplo, estão associadas com alta expressão de SLUG e consequentemente, baixa expressão de E-caderina e outros supressores de tumores (WANG et al., 2009a). Em casos de leucemia, SLUG pode agir como um fator anti-apoptótico, devido sua regulação à proteína E2A-HLF (INUKAI et al., 1999). A atividade de SLUG também está associada com a inativação dos genes supressores de tumor BRCA2 e do receptor de vitamina D (VDR) no câncer de mama, aumentando as taxas de proliferação das células nesses tumores (MITTAL et al., 2008; TRIPATHI et al., 2005). Há também uma associação da expressão de SLUG a resistência a alguns quimioterápicos como cisplatina (HASLEHURST et al., 2012), adriamicina (VITALI et al., 2008), paclitaxel, docetaxel e doxorrubicina (IŞERI et al., 2011).

SLUG também apresenta um papel fundamental na aquisição de características de CITs. Esse fator de transcrição age na regulação de uma série de genes e de vias moleculares, auxiliando na manutenção do estado de CT e também de CITs, devido, primeiramente, à repressão de genes epiteliais durante EMT. Para isso SLUG se liga à região promotora de genes como a E-caderina e citoqueratinas e recruta um complexo epigenético, conhecido como complexo "polycomb repressor" (PRC2), o qual contém, principalmente, indutores de metiltransferases e deacetilases de histonas, que trabalham juntos afim de silenciar os genes epiteliais (HAJRA; CHEN; FEARON, 2002; LAMOUILLE; XU; DERYNCK, 2014). Além da função repressora, tem-se demonstrado o papel de SLUG como ativador transcricional de uma série de genes de cunho mesenquimal como vimentina e N-caderina (PALMA-NICOLÁS; LÓPEZ-COLOMÉ, 
2013; VUORILUOTO et al., 2011). SLUG também está associado à manutenção e formação de esferas, evento típico de CITs em cultivos de baixa aderência. Guo e colaboradores, por exemplo, mostraram que, em colaboração com o gene SOX9, SLUG suporta a formação de esferas tanto em células epiteliais mamárias normais, como em neoplasias mamárias, o que foi revertido quando esses genes foram silenciados (GUO et al., 2012).

\subsubsection{Fator de transcrição dedo de zinco ZEB1}

Os fatores de transcrição da família ZEB apresentam dois domínios dedo de zinco, responsáveis pela ligação ao DNA, e um homeodomínio central envolvido nas interações entre proteínas. Possuem um sítio de ligação que se liga diretamente a sequências 5'CACCT $(\mathrm{G})-3^{\prime}$, repressando ou ativando as regiões promotoras. Assim como na família SNAIL, os fatores de transcrição ZEB também precisam do auxílio de complexos de repressão e ativação transcricional para realizarem suas funções adequadamente (VANDEWALLE; VAN ROY; BERX, 2009). ZEB1 recruta co-repressores como CtBP e BRG1, inativando a expressão de seus genes alvos (Figura 7) (SÁNCHEZ-TILLÓ et al., 2010). Ao mesmo tempo, ele pode ter o auxílio de proteínas P-300 e P/CAF e SMAD, que auxiliam na ativação de alguns genes (POSTIGO et al., 2003).

Semelhante a SLUG, ZEB1 foi identificado durante o desenvolvimento embrionário de galinhas, envolvendo-se principalmente com o desenvolvimento da mesoderme e do sistema nervoso (FUNAHASHI et al., 1993). Em mamíferos, os papéis de ZEB1 foram determinados primeiramente em camundongos. Uma série de estudos foram realizados, demonstrando que a expressão de ZEB1 durante o desenvolvimento embrionário é fundamental para o completo funcionamento de alguns tecidos, sendo que sua desregulação pode levar ao surgimento de má formações e doenças (ZHANG; SUN; MA, 2015). A distrofia corneal polimorfa posterior, por exemplo, é uma doença rara e de herança genética, caracterizada pela opacidade da córnea. Essas alterações estão relacionadas com alterações na expressão de genes como VSX1 e COL8A2, todos regulados por ZEB1. Assim, na grande maioria dos pacientes que desenvolvem essa doença, são constatadas mutações no gene ZEB1 (LISKOVA et al., 2007). 
Figura 7 - Domínios protéicos funcionais de ZEB1

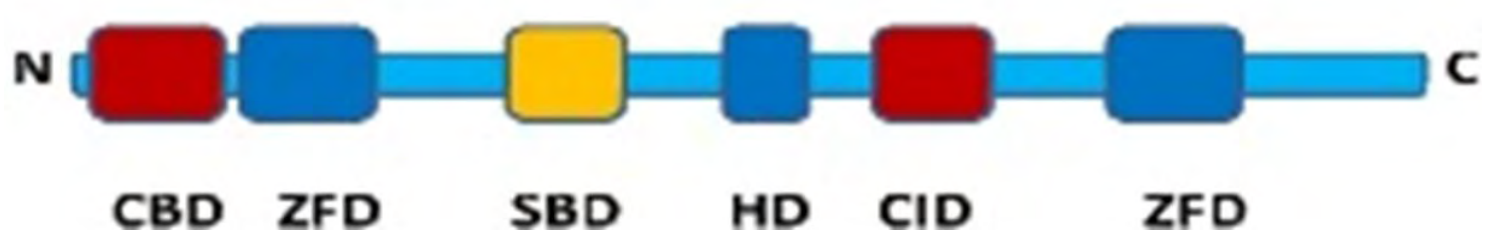

Fonte: adaptado de WELLNER, U.; BRABLETZ, T.; KECK, T. ZEB1 in pancreatic cancer. Cancers, Basel, v. 2. p 1617-1628, 2010.

Legenda: ZEB1 contém domínios dedos de zinco (ZFD), um homeodomínio central (HD), um domínio de ligação para SMAD (SBD), um domínio de interação com CtBP (CID) e um domínio de ligação coativador (CBD). O co-repressor CtBP liga-se a CID e os co-ativadores P-300 e P/CAF interagem com o domínio CBD).

A expressão de ZEB1 também está associada a uma série de tipos de cânceres como mama (LEHMANN et al., 2016), pulmão (GEMMILL et al., 2011) e fígado (ZHANG et al., 2013) e com o fenótipo de CITs. Assim como SLUG, ZEB1 é um indutor do processo de EMT, o qual está relacionado à eventos metastáticos e piores prognósticos da doença. ZEB1 pode agir tanto como um repressor transcricional de genes epiteliais e de polaridade como a E-caderina, assim como, agir como um ativador transcricional de genes mesenquimais e metaloproteinases. Sua expressão é aumentada, muitas vezes, em resposta a ativação de vias clássicas de EMT, como TGF- $\beta$ e WNT, além de fatores de crescimento que ativam a via RAS-MAPK, garantindo o fenótipo mesenquimal das células e um maior potencial de invasão e mobilidade, além das características associadas a CITs (LAMOUILLE; XU; DERYNCK, 2014; ZHANG; SUN; MA, 2015).

Além dos eventos clássicos relacionados a EMT já citados acima, e que direcionam o fenótipo de CITs, esse fator de transcrição pode regular negativamente um grupo de microRNAs que funcionam como repressores do fenômeno de stemness, principalmente dos microRNAs da família miR-200. O silenciamento do miR-200a, por exemplo, permite a superexpressão de uma proteína do complexo polycomb BMI-1, que regula o estado de célula-tronco tanto em CT como em CITs (WELLNER et al., 2009). Já a supressão do miR-200b, também inibido por ZEB1, está associada com a expressão de uma enzima modificadora de histonas, conhecida como Suz12, necessária para a repressão transcricional de genes como CDH1 (codificador da E-caderina), que está associado a perda do fenótipo epitelial e do surgimento do estado de stemness 
(ILIOPOULOS et al., 2010). Outros trabalhos também demonstraram a regulação negativa de outros microRNAs supressores do fenótipo de CITs, como miR-203 e miR183 (WELLNER et al., 2009).

Por fim, a expressão alterada desses fatores de transcrição associados a EMT está envolvida com uma série de eventos do câncer, desde sua fase de iniciação até sua fase de disseminação. Além disso, destaca-se a relação dessas moléculas com o fenótipo de CITs, população muitas vezes responsável por complicações durante o câncer. O estudo de como essas moléculas agem, em condições in vitro e in vivo, proporcionam uma ampla e interessante área de pesquisa, e suas descobertas poderiam ser de grande utilidade para o entendimento da biologia do câncer, assim como no desenvolvimento de terapias inovadoras, seguras e eficientes contra essa doença. 


\section{HIPÓTESE}

1. Há variação na expressão de fatores de transcrição associados à EMT em cultivos de células cancerosas isoladas a partir de amostras de neoplasias mamárias de cadelas com fenótipo epitelial ou mesenquimal.

2. A expressão exógena de fatores de transcrição associados à EMT em células oriundas de carcinomas mamários caninos de fenótipo epitelial, induz o processo de transição epitélio-mesenquimal e consequentemente o fenótipo de células iniciadoras tumorais (CITs). 


\section{OBJETIVOS}

1. Avaliar a expressão de fatores de transcrição associados à EMT em cultivo de células isoladas a partir de amostras de neoplasias mamárias de cadelas e sua associação com fenótipos de malignidade;

2. Avaliar os efeitos da expressão exógena de SLUG e ZEB1 em cultivos de células mamárias de cadelas com fenótipo epitelial, quanto a morfologia, expressão de filamentos intermediários, tempo de duplicação celular, expressão de genes associados a EMT, resistência aos quimioterápicos doxorrubicina e paclitaxel, potencial de invasão e formação de tumoresferas em placas de baixa aderência. 


\section{MATERIAL E MÉTODOS}

\subsection{CULTIVOS DE CÉlULAS ORIUNDAS DE NEOPLASIAS MAMÁRIAS CANINAS}

Os quatro cultivos de células utilizados nessa dissertação (CC-20E, CL-28E, CB5M e CL-25M) foram isolados a partir de amostras de carcinomas mamários de cadelas atendidos em clínicas veterinárias parceiras de Pirassununga-SP e região. Essas células foram isoladas e caracterizadas durante a dissertação da pós-graduanda Yonara Gouveia Cordeiro (CORDEIRO, 2015).

Todas as células foram cultivadas por 25 passagens, com o propósito de obtermos uma população clonal e uniforme de células. Todos os experimentos seguintes foram realizados a partir dos clones p25. As células foram então cultivadas em meio de cultivo DMEM/F-12 (Thermo Fisher Scientific, EUA) suplementado com 10\% de soro fetal bovino (SFB) e $1 \%$ de antibiótico/antimicótico (Thermo Fisher, EUA), em estufa à $37^{\circ} \mathrm{C}$ e $5 \%$ de $\mathrm{CO}_{2}$. O meio de cultivo foi substituído a cada dois dias para a manutenção das células. Quando atingiam 70-80\% de confluência, as células eram desprendidas das garrafas através da utilização de tripsina TrypLE ${ }^{\mathrm{TM}}$ Express $1 \mathrm{X}$ (Thermo Fisher Scientific, EUA). Para isso, todo o meio de cultivo da garrafa era descartado e adicionavase $5 \mathrm{ml}$ de PBS, com a intenção de remover os debris celulares, contaminantes e restos de SFB, que poderiam inibir a ação da tripsina. Logo após o descarte do PBS, $1 \mathrm{ml}$ de tripsina TrypLE $^{\mathrm{TM}}$ Express (Thermo Fisher Science) era adicionado. As células foram então ressuspendidas em $5 \mathrm{ml}$ de meio de cultivo, suplementado com 10\% de SFB, afim de inativar a tripsina. Após a tripsinização, $10 \%$ das células retornavam ao cultivo, sob as mesmas condições. A cada 5 passagens, três vias de células eram ressuspendidas em $1 \mathrm{ml}$ de DMEM-F12 suplementado com 10\% de SFB e 10\% de de dimetil sulfóxido (DMSO), colocadas em criotubos e armazenadas em nitrogênio líquido. 


\subsection{AVALIAÇÃO DA DISPOSIÇÃO DOS FILAMENTOS DE ACTINA POR COLORAÇÃO DE FALOIDINA}

Para analisar a disposição dos filamentos de actina nas células foi utilizado o teste de coloração de faloidina (Phalloidin Atto 565 - Sigma aldrich, EUA). Essa consiste em um peptídeo com alta afinidade para F-actina, conjugado ao corante fluorescente vermelho-laranja, tetrametilrodamina (TRITC). Para isso, cerca de 10.000 células foram plaqueadas em placas de 96 poços e incubadas a $37^{\circ} \mathrm{C}$ e $5 \%$ de $\mathrm{CO}_{2}$ durante 24 horas. Após, foram lavadas 2 vezes com PBS 1x e fixadas com paraformaldeído (PFA) a 4\%, durante 30 minutos. O PFA foi retirado e as células lavadas duas vezes com PBS, e logo em seguida foram adicionados $50 \mu 1$ de faloidina diluída 100 vezes em PBS 1x. A placa foi então envolvida em papel alumínio e incubada em temperatura ambiente durante 30 minutos. As células foram lavadas 2 vezes com PBS e em seguida $50 \mu 1$ de DAPI (4',6diamidino-2-phenylindole - ThermoScientific - Carlsbad, CA, EUA), em uma concentração de $2 \mu \mathrm{g} / \mathrm{ml}$, foram adicionados para a coloração do núcleo das células. Novamente, a placa foi envolta com papel alumínio e incubada durante 15 minutos. Mais 2 lavagens com PBS 1x foram realizadas e por fim $100 \mu \mathrm{l}$ de ProLong (2 gotas por $1 \mathrm{ml}$ de PBS 1x) foram adicionados para a manutenção da fluorescência a longo prazo. As células foram então observadas em microscópio invertido (ZEISS - Axio Vert A1) e fotografadas com câmera acoplada (Axio Can 503), utilizando filtro de comprimento de onda de $540 \mathrm{~nm}$ para a observação dos filamentos de actina e filtro de comprimento de onda de $358 \mathrm{~nm}$ para a observação do núcleo marcado com DAPI.

\subsection{EXTRAÇÃO DE RNA E TRATAMENTO COM DNASE}

Após 25 passagens, células foram cultivadas até atingirem 70-80\% de confluência, tripsinizadas e contadas em câmara de Neubauer. Cerca de $10^{6}$ células foram colocadas em tubos eppendorf de $1,5 \mathrm{ml}$ e centrifugadas a $1.500 \mathrm{rpm}$ por 10 minutos. $\mathrm{O}$ sobrenadante era então descartado e adicionava-se $1 \mathrm{ml}$ de PBS para lavagem. Novamente, as células eram centrifugadas e o PBS descartado. O pellet foi então armazenado em $-80^{\circ} \mathrm{C}$ até sua utilização.

A extração do RNA total foi realizada com o reagente Trizol (Thermo Scientific, $E U A$ ), seguindo-se o protocolo do fabricante. Para isso, esperava-se o descongelamento do pellet de células em gelo e adicionava-se $800 \mu \mathrm{l}$ de Trizol a cada tubo. As amostras 
eram então levadas ao vortex e depois incubadas por 5 minutos em temperatura ambiente, para a completa dissociação das membranas celulares e liberação das macromoléculas. $160 \mu 1$ de clorofórmio eram adicionados a cada tubo, os quais eram mixados por inversão e incubados por mais 3 minutos. As amostras eram então centrifugadas à $12.000 \mathrm{~g}$, durante 15 minutos e a $4^{\circ} \mathrm{C}$. Logo após a centrifugação, 3 fases eram visualizadas. A fase aquosa e incolor, a qual continha o RNA, era então pipetada para um outro tubo eppendorf de $1,5 \mathrm{ml}$ e o restante era armazenado em $-80^{\circ} \mathrm{C}$. O RNA foi então precipitado com a adição de $400 \mu 1$ de álcool isopropílico puro. Após 10 minutos em temperatura ambiente, as amostras eram centrifugadas a $12.000 \mathrm{~g}$, durante 10 minutos e a $4^{\circ} \mathrm{C}$. O sobrenadante era descartado e o pellet, o qual continha o RNA, era ressuspendido com $800 \mu 1$ de álcool etílico $75 \%$ e levado ao vórtex. Após, centrifugava-se as amostras em $7.500 \mathrm{~g}$, durante 5 minutos e a $4^{\circ} \mathrm{C}$. Essa etapa de lavagem foi realizada duas vezes. Por último, o sobrenadante era descartado e incubadas a temperatura ambiente por 10 minutos. Após, as amostras eram ressuspendidas em $50 \mu \mathrm{l}$ de água livre de RNAse. A quantidade e qualidade do RNA extraído foram analisados pelo equipamento NanoDrop 2000 (Thermo Scientific, EUA) e por gel de agarose. Foram consideradas apropriadas para uso, as amostras que apresentaram razão A260/A280 entre 1.8 e 2.1 e bandas ribossomais 18s e 28s íntegras no gel de agarose.

Após quantificação e avaliação da integridade, as amostras de RNA foram tratadas com DNAse do tipo I e livre de RNAse (Thermo Scientific, EUA), para a degradação de possíveis fragmentos de DNA. Para isso, todas as concentrações de RNA foram ajustadas para $200 \mathrm{ng} / \mu \mathrm{l}$. Logo após, foi adicionado o buffer DNAse 10x em uma concentração de 1x e $2 \mathrm{U}$ de DNAse do tipo I. As amostras foram então incubadas em termociclador durante 30 minutos e a $37^{\circ} \mathrm{C}$. Após, elevava-se a temperatura a $75^{\circ} \mathrm{C}$ durante 10 minutos, afim de inativar a DNAse. Para essa etapa, foi adicionado EDTA em uma concentração de 5mM, afim de evitar a degradação do RNA devido à alta temperatura. 


\subsection{TRANSCRIÇÃO REVERSA E ANÁLISES DE EXPRESSÃO GÊNICA RELATIVA POR PCR EM TEMPO REAL}

Os mRNAs foram então transcritos reversamente para cDNA utilizando-se o kit "High Capacity cDNA Reverse Transcription" (Thermo Scientific, EUA). Para isso, padronizou-se uma reação contendo $20 \mu \mathrm{l}$ com uma concentração final de RNA de 50 ng/ $\mu 1$. Desses $20 \mu \mathrm{l}$ padronizados, $2 \mu \mathrm{l}$ correspondiam ao buffer RT 10X, $2 \mu 1$ de primers oligo(dt), 0,8 $\mu \mathrm{l}$ de um mix contendo desoxirribonucleotídeos fosfatados (dNTP) e $1 \mu \mathrm{l}$ da enzima transcriptase reversa MultiScribe (Thermo Fisher Scientific, EUA). Completava-se a reação com água livre de RNAse para um total de $20 \mu 1$. As amostras eram então levadas ao termociclador e incubadas a $25^{\circ} \mathrm{C}$ durante 10 minutos, $37^{\circ} \mathrm{C}$ durante 2 horas e a $75^{\circ} \mathrm{C}$ durante 5 minutos, para inativação da reação. As amostras de cDNA foram então armazenadas a $-20^{\circ} \mathrm{C}$ até sua utilização.

As análises de expressão gênica relativa foram realizadas por PCR em tempo real, utilizando o equipamento StepOne System (Thermo Fisher Scientific, EUA). As reações foram preparadas em um volume total de $10 \mu$, contendo $5 \mu 1$ do reagente Fast SYBR Green Master Mix (Applied BioSystem, EUA), o volume de primers correspondentes a sua concentração padronizada, $1 \mu \mathrm{l}$ de cDNA e o restante completado com água livre de RNAses. A reação foi realizada com 1 ciclo de 20 segundos a $95^{\circ} \mathrm{C}$ e 40 ciclos de 3 segundos a $95^{\circ} \mathrm{C}$ e 30 segundos a $60^{\circ} \mathrm{C}$. Os primers utilizados para a amplificação de genes específicos foram desenhados em regiões de dois éxons diferentes, de forma que houvesse uma região de íntron entre eles, evitando assim resultados falsos positivos oriundos da amplificação de DNA genômico. Para o desenho dos primers, foi utilizado o programa Primer-BLAST (YE et al., 2012) e para a verificação da formação de dímeros e hairpins foi utilizado o programa AutoDimer (VALLONE; BUTLER, 2004). Por fim, os primers foram testados por PCR In Silico, disponível na plataforma UCSC Genome Bioinformatics. Os primers desenhados estão descritos na tabela 3. A expressão do RNA ribossomal $18 \mathrm{~S}$ foi utilizada como gene endógeno e normalizador das reações. Todas as reações foram realizadas com seis replicatas biológicas e em duplicata técnica. As análises de expressão gênica foram realizadas pelo método de 2DDCT (LIVAK; SCHMITTGEN, 2001). 
Tabela 2 - Primers específicos utilizados nas reações de PCR em tempo real

\begin{tabular}{cc}
\hline Primers & Sequência $\left.\mathbf{( 5}^{\prime}>\mathbf{3}^{\prime}\right)$ \\
\hline $\mathbf{1 8 S}$ FW & CCTGCGGCTTAATTGACTC \\
$\mathbf{1 8 S}$ RV & CTGTCAATCCTGTCCGTGTC \\
ABCB1 FW & CCTGGACAAAGCCAGAGAAG \\
ABCB1 RV & TTTGCCATTCTGAAACACCA \\
BRCA2 FW & CGAGTCCCCTCTGCATGTTC \\
BRCA2 RV & CTGAAAAGACTCTGCATTTTTGCTG \\
CDH1 FW & AGGCCCATTTCCTAAAAACC \\
CDH1 RV & TTGGCCAGTGATGCTGTAGA \\
CDH2 FW & CCTTCATGCTGGGACCATGT \\
CDH2 RV & TTTGCCCGTTCACAGGATCT \\
HDAC1 FW & AGGCATCTGGCTTCTGTTACG \\
SLUG FW & CGTTTTCCAGACCCTGGTTA \\
SLUG RV & GCAGTGAGGGCAAGAAAAAG \\
STAT3 FW & GCCAATGCTAGAGGAGAGGA \\
STAT3 RV & AACTGGACGCCAGTCTTGAT \\
VDR FW & CAGCCAGGACTACAAGTACCG \\
VDR RV & CCTGGAACTTGATGAGGGGC \\
ZEB1 FW & TTGCTCCCTGTGCAGTTACA \\
ZEB1 RV & AGCTTTCCCACATTCAGTGC \\
ZEB2 FW & ACCCAGGACTGGATCAGATG \\
ZEB2 RV & GCTCCATCAAGCAATTCTCC \\
\hline
\end{tabular}

Fonte: XAVIER, P. L. P. 2016.

Legenda: Sequências foward e reverse dos primers, descritas no sentido 5' - 3'

\subsection{PREPARAÇÃO DOS PLASMÍDEOS CONTENDO AS REGIÕES} CODIFICANTES DOS GENES SLUG E ZEB1

\subsubsection{Preparação das bactérias competentes}

Primeiramente, bactérias da espécie Escherichia coli, foram induzidas ao estado de competência através do método químico utilizando cloreto de cálcio $\left(\mathrm{CaCl}_{2}\right)$. Para isso, as bactérias foram plaqueadas em placas de petri contendo $20 \mathrm{ml}$ de ágar dissolvido em meio de cultivo Luria-Bertani (LB) (Sigma Aldrich, EUA) e mantidas em estufa a $37^{\circ} \mathrm{C}$ e overnight para o crescimento das colônias. Após o crescimento, uma colônia foi capturada e transferida para um tubo falcon contendo $50 \mathrm{ml}$ de meio de cultivo LB. Esse foi incubado em um agitador a $37^{\circ} \mathrm{C}$ e a uma velocidade de $250 \mathrm{rpm}$, até que as bactérias proliferassem em quantidade suficiente para turvar o meio de cultivo. Após, os tubos foram centrifugados a $4.000 \mathrm{rpm}$ durante 10 minutos e a $4^{\circ} \mathrm{C}$. O sobrenadante foi 
descartado e o pellet de bactérias foi incubado em gelo. O pellet foi então ressuspendido em $15 \mathrm{ml}$ de solução gelada contendo $100 \mathrm{mM}$ de $\mathrm{MgCl}_{2}$. Novamente, o tubo foi centrifugado a $4.000 \mathrm{rpm}$, durante 10 minutos e a $4^{\circ} \mathrm{C}$. $\mathrm{O}$ sobrenadante foi então descartado e o pellet ressuspendido em $20 \mathrm{ml}$ de solução gelada contendo $100 \mathrm{mM}$ de $\mathrm{CaCl}_{2}$ e incubado em gelo durante 20 minutos. A cada 3 minutos, o tubo era agitado manualmente afim de manter o pellet em suspensão. Após, o tubo foi centrifugado nas mesmas condições anteriores, o sobrenadante descartado e o pellet de bactérias ressuspendido em $2 \mathrm{ml}$ de solução contendo $85 \mathrm{mM}$ de $\mathrm{CaCl}_{2}$ e $15 \%$ de glicerol. Alíquotas de $100 \mu \mathrm{l}$ das bactérias competentes foram produzidas e armazenadas a $-80^{\circ} \mathrm{C}$ até sua utilização.

\subsubsection{Processo de transformação, clonagem e purificação dos plasmídeos}

As regiões codificantes (ORFs) dos genes SLUG (NM_001097981) e ZEB1 caninos (XM_003433703) foram adquiridas de empresa especializada (GenScript, EUA). Ainda na empresa, as ORFs foram clonadas em vetores plasmidiais do tipo FUGW, o qual contém, principalmente, uma região codificadora de ubiquitina, uma sequência para resistência ao antibiótico ampicilina e uma sequência para a expressão da proteína sinalizadora eGFP (Figura 8). Os plasmídeos foram então recebidos de forma liofilizada. Primeiramente, foram centrifugados a $6.000 \mathrm{~g}$, durante 1 minuto e a $4^{\circ} \mathrm{C}$. Após, foram ressuspendidos em $20 \mu 1$ de água livre de RNAses e agitados em vórtex durante 1 minuto. Duas alíquotas de bactérias competentes, preparadas durante a etapa 3.4.1, foram então colocadas em gelo, e $2 \mu 1$ de cada plasmídeo foram pipetados diretamente nas bactérias. Um choque térmico foi realizado afim de induzir o processo de transformação, ou seja, da incorporação dos plasmídeos pelas bactérias. Para isso, os tubos foram incubados em banho maria à $42^{\circ} \mathrm{C}$, durante 45 segundos e depois retornados ao gelo, durante 5 minutos.

As bactérias foram então transferidas para um tubo eppendorf de $1,5 \mathrm{ml}$, contendo $300 \mu \mathrm{l}$ de meio de cultivo LB e incubadas a $250 \mathrm{rpm}$ e a $37^{\circ} \mathrm{C}$, durante 50 minutos. Após, $120 \mu 1$ do meio LB contendo as bactérias foram transferidos para placas de petri contendo $20 \mathrm{ml}$ de meio LB e ágar, além de ampicilina em uma concentração de $100 \mu \mathrm{g} / \mathrm{ml}$ para a seleção das bactérias resistentes. A solução foi homogeneizada com uma pipeta pasteur, de modo que a mesma se espalhasse por toda a placa. As placas foram então incubadas em estufa a $37^{\circ} \mathrm{C}$ e overnight para o crescimento das colônias. Uma colônia foi capturada 
e transferida para um tubo falcon de $15 \mathrm{ml}$, contendo $2 \mathrm{ml}$ de meio LB com ampicilina e as placas de petri com o restante das colônias, foram armazenadas em geladeira, caso necessárias para utilizações posteriores. Os tubos foram então incubados a $250 \mathrm{rpm}$ e a $37^{\circ} \mathrm{C}$ por aproximadamente 6 horas, tempo suficiente para a proliferação das bactérias e para o turvamento do meio de cultivo. Em seguida, $1 \mathrm{ml}$ das bactérias foi transferido para garrafas de $500 \mathrm{ml}$, contendo $100 \mathrm{ml}$ de meio de cultivo LB e ampicilina e o restante foi congelado a $-80^{\circ} \mathrm{C}$, em solução de glicerol $35 \%$. As garrafas foram incubadas a $250 \mathrm{rpm}$, $37^{\circ} \mathrm{C}$ e overnight. Após, as bactérias foram divididas em tubos falcon de $50 \mathrm{ml}$ e centrifugadas a $6.000 \mathrm{~g}$, a $4^{\circ} \mathrm{C}$ e durante 15 minutos. O sobrenadante foi descartado e o pellet armazenado a $-80^{\circ} \mathrm{C}$.

Figura 8 - Sequência do plasmídeo FUGW

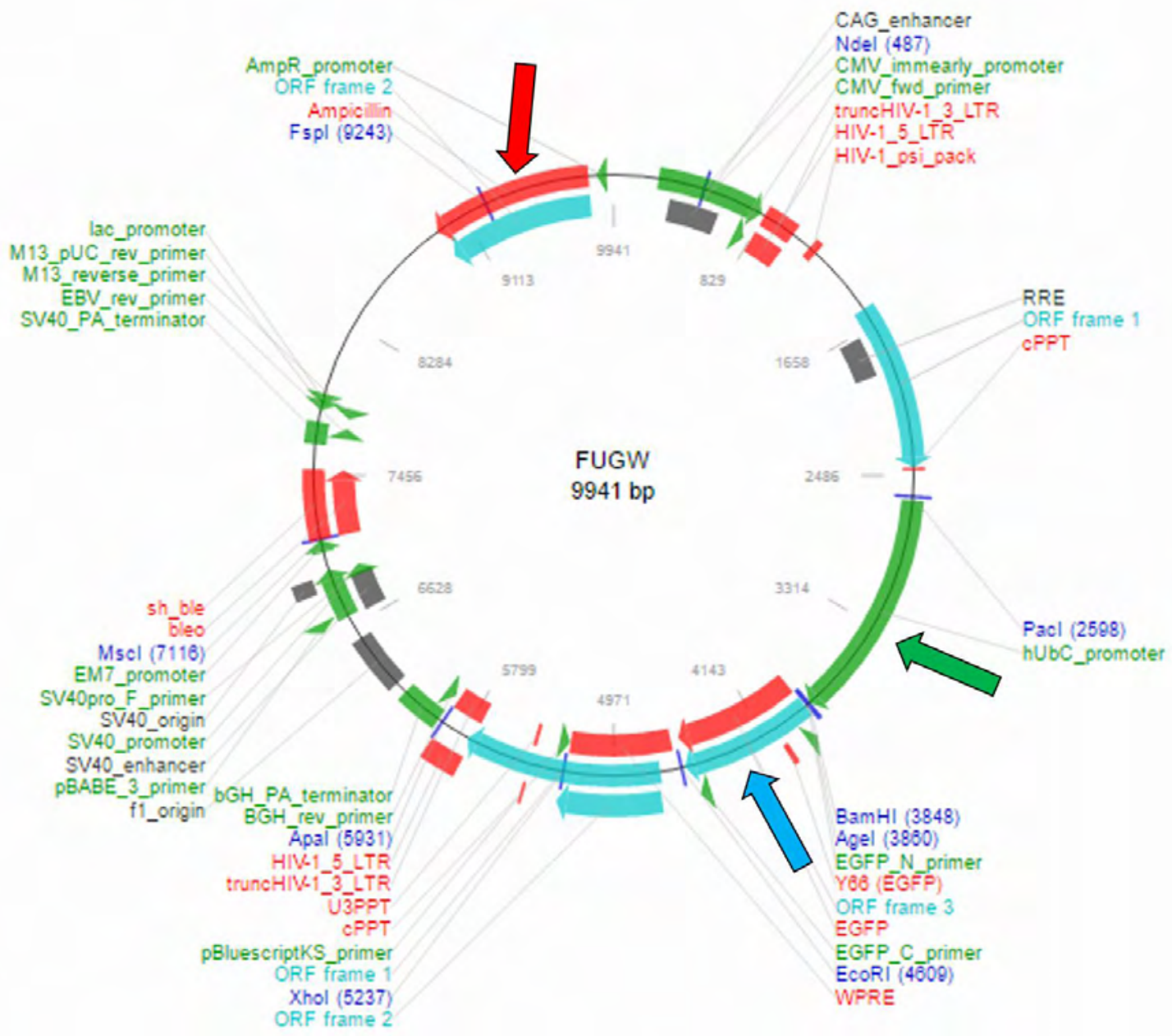

Fonte: adaptado de LOIS et al. Germline transmission and tissue-specific expression. of transgenes delivered by lentiviral vector. Science, Washington, v. 295. p 868-872, 2002.

Legenda: Sequência de todas as regiões contidas no plasmídeo FUGW. A seta vermelha aponta para a sequência do gene de resistência para o antibiótico ampicilina. A seta verde aponta a região aonde estão inseridas a região promotora de ubiquitina, seguida pelas ORFs dos genes SLUG e ZEB1. Por fim, a seta azul aponta para a sequência do gene eGFP. 
A purificação dos plasmídeos foi realizada utilizando-se o kit EndoFree Plasmid Maxi (Qiagen, Alemanha). Inicialmente, o pellet de bactérias foi ressuspendido em $10 \mathrm{ml}$ de buffer P1 e $10 \mathrm{ml}$ de buffer P2 para permitir a lise das células e liberação dos componentes intracelulares. $\mathrm{O}$ tubo foi invertido manualmente 10 vezes e incubado por 5 minutos em temperatura ambiente. Após, $10 \mathrm{ml}$ do buffer P3 foram adicionados a solução e misturado por inversão. A solução foi então transferida para uma seringa QIAfilter e incubado por 10 minutos em temperatura ambiente. Em seguida, a solução foi filtrada em um tubo falcon de $50 \mathrm{ml}$ e adicionado $2,5 \mathrm{ml}$ do buffer ER. A solução foi invertida manualmente 10 vezes e incubada em gelo por 30 minutos. Entre os 30 minutos, a barreira QIAGEN-tip 500 foi equilibrada adicionando-se $10 \mathrm{ml}$ de buffer QBT e permitindo que a barreira se esvaziasse por fluxo gravitacional. Em seguida, transferiu-se a solução filtrada para a barreira e permitiu-se que se esvaziasse por fluxo gravitacional. A barreira foi então lavada 2 vezes com $30 \mathrm{ml}$ do buffer QC. O DNA plasmidial foi então eluido da barreira adicionando-se $15 \mathrm{ml}$ de buffer QN em um novo tubo falcon de $50 \mathrm{ml}$. Adicionou-se 10,5 ml de álcool isopropílico para a precipitação do DNA. Os tubos foram então centrifugados a $5.000 \mathrm{~g}$ por 2 horas e a $4^{\circ} \mathrm{C}$. Após, o sobrenadante foi descartado e o pellet ressuspendido em $5 \mathrm{ml}$ de etanol $70 \%$ livre de endotoxinas para a lavagem. Novamente, os tubos foram centrifugados a $5.000 \mathrm{~g}$ por 2 horas e a $4^{\circ} \mathrm{C}$. O sobrenadante foi descartado e o pellet ressuspendido em buffer TE livre de endotoxinas. A concentração e a razão 260/280 do DNA plasmidial foi analisada pelo equipamento NanoDrop 2000.

\subsection{PROCESSO DE TRANSFECÇÃO DAS CÉLULAS 293FT E TRANSDUÇÃO ESTÁVEL DOS GENES SLUG E ZEB1 POR TRANSDUÇÃO LENTIVIRAL}

A transfecção foi realizada utilizando-se células empacotadoras $293 \mathrm{ft}$ e o reagente lipofectamina 3000 (Thermo Fisher, EUA). Primeiramente, células 293ft foram cultivadas em garrafas de $75 \mathrm{~cm}^{2}$, em meio de cultivo DMEM suplementado com GlutaMAX e $10 \%$ de soro fetal bovino, a $38,5^{\circ} \mathrm{C}$ e $5 \%$ de $\mathrm{CO}_{2}$. Ao atingir cerca de $70 \%$ de confluência, as células foram transfectadas, sendo que uma garrafa recebeu os plasmídeos contendo a ORF do gene SLUG (FUGW-SLUG), outra com plasmídeos contendo a ORF do gene ZEB1 (FUGW-ZEB1) e uma com plasmídeos contendo apenas a ORF para o gene eGFP (FUGW-eGFP), considerada controle positivo. Para isso, preparou-se para cada garrafa, 1,5 ml de meio DMEM livre de SFB e antibiótico, suplementados com $36 \mu 1$ de lipofectamina 3000. Em outros tubos separados, preparou- 
se 1,5 ml de meio DMEM livre de SFB e antibiótico contendo $5 \mu \mathrm{g}$ de cada plasmídeo, junto a 1,2 $\mu \mathrm{g}$ dos plasmídeos virais pLP1 e pLP2, e 2,4 $\mu \mathrm{g}$ do plasmídeo viral VSV.G. O meio contendo a lipofectamina foi adicionada junto ao meio contendo os plasmídeos e incubados por 5 minutos em temperatura ambiente. Esse foi então utilizado para a infecção das células $293 \mathrm{ft}$ e consequente produção dos lentivírus contendo as sequências dos genes de interesse. Após 48 horas, o sobrenadante infectado foi coletado e utilizado para a transdução das células de interesse.

Cerca de $3 \times 10^{4}$ células das células CC-20E e CL-28E foram colocadas em placas de 6 poços e cultivadas até atingirem $70 \%$ de confluência. O meio de cultivo foi então removido e as células foram transduzidas com o sobrenadante contendo as partículas lentivirais adicionados de polibreno em uma concentração de $8 \mu \mathrm{g} / \mathrm{ml}$ (Sigma-Aldrich, EUA), durante 24 horas. Após, as células foram transduzidas novamente com o mesmo sobrenadante. A transdução foi mantida por mais 48 horas e então visualizadas em microscopia de fluorescência para a detecção de eGFP, em um comprimento de onda de $395 \mathrm{~nm}$.

\subsection{ENRIQUECIMENTO DAS CÉLULAS POSITIVAS PARA EGFP ATRAVÉS DE SEPARAÇÃO POR CITOMETRIA DE FLUXO}

As células transduzidas com os genes SLUG e ZEB1 foram cultivadas em garrafas de $75 \mathrm{~cm}^{3}$ até atingirem cerca de $80 \%$ de confluência e então foram tripsinizadas. Cerca de $10^{7}$ células foram concentradas em $1 \mathrm{ml}$ de PBS contendo $5 \mathrm{mM}$ de EDTA e filtradas em tubos estéreis de $5 \mathrm{ml}$ utilizando um mesh de 100 micrômetros, evitando assim debris e aglomerados de células. A população total de células positivas para eGFP foi então analisada e separada pelo citômetro de fluxo S3 Cell Sorter (Bio Rad, EUA).

\subsection{TEMPO DE DUPLICAÇÃO CELULAR}

Para avaliação da taxa de proliferação das células, foram cultivadas $5 \times 10^{4}$ células por poço, em placa de 6 poços, com meio de cultivo suplementado conforme descrito anteriormente. O número de células foi contado em câmara de Neubauer em intervalos de 24 horas, por um período total de 120 horas. Todas as amostras foram contadas no mesmo horário, e da mesma forma durante todo o experimento. Os resultados foram 
avaliados através do programa Doubling-Time (http://doubling-time.com/compute.php). A avaliação foi realizada em duplicata técnica.

\subsection{AVALIAÇÃO DA EXPRESSÃO DE CITOQUERATINA E VIMENTINA POR IMUNOFLUORESCÊNCIA}

Cerca de $10^{4}$ células foram plaqueadas em placas de 96 poços e incubadas a $37^{\circ} \mathrm{C}$ e 5\% de CO2 durante 24 horas. Após, foram lavadas 2 vezes com PBS 1x e fixadas com paraformaldeído (PFA) a 4\%, durante 30 minutos. O PFA foi retirado e as células lavadas duas vezes com PBS. Então foi realizado o bloqueio utilizando leite a 5\%, diluído em PBS 1x, durante 30 minutos em temperatura ambiente. O anticorpo primário foi diluído em uma concentração de 1:100, utilizando PBS/Tween $0,1 \%$ adicionado de BSA a $0,1 \%$ para todas as marcações realizadas, sendo preparados $50 \mu \mathrm{L}$ de solução para cada poço. As células foram então incubadas overnight à $4^{\circ} \mathrm{C}$ e após lavadas 3 vezes com PBS. O anticorpo secundário foi então diluído em uma concentração de 1:250 e as células foram incubadas durante 1 hora em temperatura ambiente. Após, as células foram lavadas 3 vezes com PBS e então incubadas com Hoechst por 10 minutos para a marcação dos núcleos. A solução de Hoechst foi então retirada e as células lavadas com PBS por mais 3 vezes. Após, as células foram então observadas em microscópio invertido (ZEISS Axio Vert A1) e fotografadas com câmera acoplada (Axio Can 503), utilizando filtro de comprimento de onda de $540 \mathrm{~nm}$ para a observação dos filamentos intermediários e filtro de comprimento de onda de $358 \mathrm{~nm}$ para a observação do núcleo marcado com Hoescht.

\subsection{AVALIAÇÃO DE CITOTOXIDADE DOS QUIMIOTERÁPICOS DOXORRUBICINA E PACLITAXEL}

O efeito citotóxico dos quimioterápicos doxorrubicina e paclitaxel entre as células controle e com expressão exógena de SLUG foi avaliado utilizando o ensaio de MTT. Para isso, cerca de $5 \times 10^{3}$ células foram concentradas em um volume de $100 \mu \mathrm{l} /$ poço, plaqueadas em placas de 96 poços e incubadas durante 24 horas para aderência. Após, o meio de cultivo foi retirado e um novo meio de cultivo contendo diferentes concentrações em diluições seriadas dos quimioterápicos doxorrubicina e paclitaxel foram adicionados. As células foram expostas aos fármacos durante 48 horas, quando então foram 
adicionados $10 \mu \mathrm{l} /$ poço de MTT em uma concentração de $5 \mathrm{mg} / \mathrm{ml}$ e incubadas em estufa a $37^{\circ} \mathrm{C}$ e $5 \%$ de $\mathrm{CO} 2$, durante 2 horas. Em seguida, o meio de cultivo com MTT foi retirado e $100 \mu \mathrm{l} /$ poço de álcool isopropílico acídico $(0,04 \mathrm{M}$ de $\mathrm{HCL}$ em álcool isopropílico absoluto) foram adicionados para a diluição dos cristais de formazan, produzidos pela metabolização do MTT pelas células viáveis. As placas foram lidas em um espectrofotômetro com $570 \mathrm{~nm}$ de comprimento de onda. Os valores de absorbância foram então utilizados para o cálculo da concentração de inibição de $50 \%$ da viabilidade celular $\left(\mathrm{IC}_{50}\right)$. Os testes foram realizados em triplicata.

\subsection{ENSAIO DE INVASÃO EM INSERTOS TRANSWELL}

A capacidade de invasão das células foi analisada por ensaio de invasão em insertos transwell preenchidos com gel ECM, afim de mimetizar a matriz extracelular. Para a realização desse teste, todos os materiais utilizados foram previamente descongelados e resfriados em geladeira, afim de evitar a polimerização precoce do gel ECM. As células foram cultivadas por 24 horas com meio de cultivo livre de soro fetal bovino. Após, os insertos foram inseridos em placas de 24 poços e preenchidos com $100 \mu 1$ do gel ECM diluído em PBS (1:5). A placa foi incubada a $37^{\circ} \mathrm{C}$ durante 4 horas, para a polimerização do gel. O número de células plaqueadas foi ajustado para cerca de 40.000 células/inserto, em um volume de $100 \mu 1 /$ inserto. $600 \mu 1$ de meio DMEM-F12 suplementado com $20 \%$ de soro fetal bovino foram adicionados a cada poço, servindo como um quimioatrativo para as células. Após 24 horas, o meio de cultivo foi retirado dos insertos e esses foram lavados em PBS. A parte superior do inserto foi limpa com um swab, afim de retirar as células que não invadiram o gel. Em seguida, o inserto foi colocado novamente em uma placa de 24 poços e fixado com $1 \mathrm{ml}$ de glutaraldeído $5 \%$ durante 10 minutos. Os insertos foram então lavados 2 vezes em PBS e corados com cristal violeta por 2 minutos. Após, foram lavados 2 vezes em PBS e mais uma vez o swab foi passado na parte superior do inserto para a retirada total das células não invasivas. As células invasivas foram contadas em microscópio óptico, em um aumento de 100 vezes, em 5 campos aleatórios. Os ensaios foram realizados em triplicata. 


\subsection{CULTIVO CELULAR PARA FORMAÇÃO DE TUMORESFERAS}

A capacidade de formação de tumoresferas foi realizada em placas de baixa aderência. Para isso, cerca de 750 células foram plaqueadas em placas de baixa aderência (24-well low-adherent plates, Corning ${ }^{\circledR}, \mathrm{USA}$ ) em um volume de $0,5 \mathrm{ml} /$ poço. O meio utilizado foi DMEM-F12 suplementado com $20 \mathrm{ng} / \mathrm{ml}$ de EGF (PrepoTech, USA), 10 ng/ml de FGF (PrepoTech, USA), 5 $\mu 1 / \mathrm{ml}$ de insulina bovina (Sigma Aldrich $®$, MO, USA) e 1\% de antibiótico/antimicótico (PenStep, Gibco, Life Technologies®, USA). Para manutenção do cultivo celular, $40 \mu \mathrm{l} /$ poço de meio fresco foram adicionados a cada 48 horas. As esferas foram contadas e medidas nos dias 7, 14 e 21 de cultivo. Foram contados 9 poços para cada célula. Para a avaliação do tamanho das esferas, dez esferas foram fotografadas para cada cultivo, e então seu diâmetro foi medido utilizando o software do próprio microscópio (ZEISS - Axio Vert A1).

\subsection{ANÁLISE ESTATÍSTICA}

Para a avaliação de significância da expressão gênica dos fatores de transcrição nos cultivos celulares iniciais, foi utilizado análise de variância (ANOVA), em uma via para comparações múltiplas entre os cultivos, realizada pelo teste de Tukey. Para análise da $\mathrm{IC}_{50}$, foi utilizado o método de regressão não linear com parâmetros de inibição dose resposta. Para comparação dos resultados obtidos entre as células controle e as células com expressão exógena de SLUG, foi utilizado, primeiramente, o teste de KolmogorovSmirnov para determinação da normalidade dos dados. Para aqueles considerados normais, utilizou-se teste t paramétrico de Student. Para aqueles não considerados normais, utilizou-se o teste não paramétrico de Mann-Whitney. Todas as análises e confecção dos gráficos foram geradas pelo programa GraphPad Prism® ${ }^{\circledR} .0$ (San Diego, CA, USA). Diferenças com $(\mathrm{P})<0,05$ foram consideradas significantes. 


\section{RESULTADOS}

\subsection{EXPERIMENTO 1: CARACTERIZAÇÃO MORFOLÓGICA DOS CULTIVOS CELULARES E AVALIAÇÃO DA EXPRESSÃO GÊNICA DE FATORES DE TRANSCRIÇÃO ASSOCIADOS A TRANSIÇÃO EPITÉLIO MESENQUIMAL}

\subsubsection{Caracterização morfológica por microscopia óptica}

Os quatro cultivos celulares utilizados durante esse estudo, foram caracterizados previamente quanto a sua morfologia, tempo de duplicação, cariótipo e expressão dos filamentos intermediários citoqueratina, vimentina e alfa-actina por imunocitoquímica (GOUVEIA, 2015). Ao caracterizá-los morfologicamente por microscopia óptica, observou-se que que os cultivos CC-20E e CL28E apresentaram fenótipo de células epiteliais, enquanto os cultivos CB-5M e CL25M apresentaram fenótipos de células mesenquimais. Individualmente, as amostras exibiram as seguintes características:

- Cultivo CC-20E: Nesse cultivo, foi observado morfologia típica de células epiteliais, as quais apresentavam formato poligonal, formação de grupos de células justapostas e pouco espaço intracelular. Os núcleos eram grandes e bem definidos, contendo nucléolos bem evidentes. Em algumas regiões da placa, notou-se algumas células com o citoplasma mais amplo do que o normal, exibindo três ou mais núcleos com nucléolos evidentes. Quando em confluência, observava-se a formação de um tapete de células, bem semelhante aos tecidos epiteliais (Figura 9). 
Figura 9 - Caracterização morfológica do cultivo CC-20E

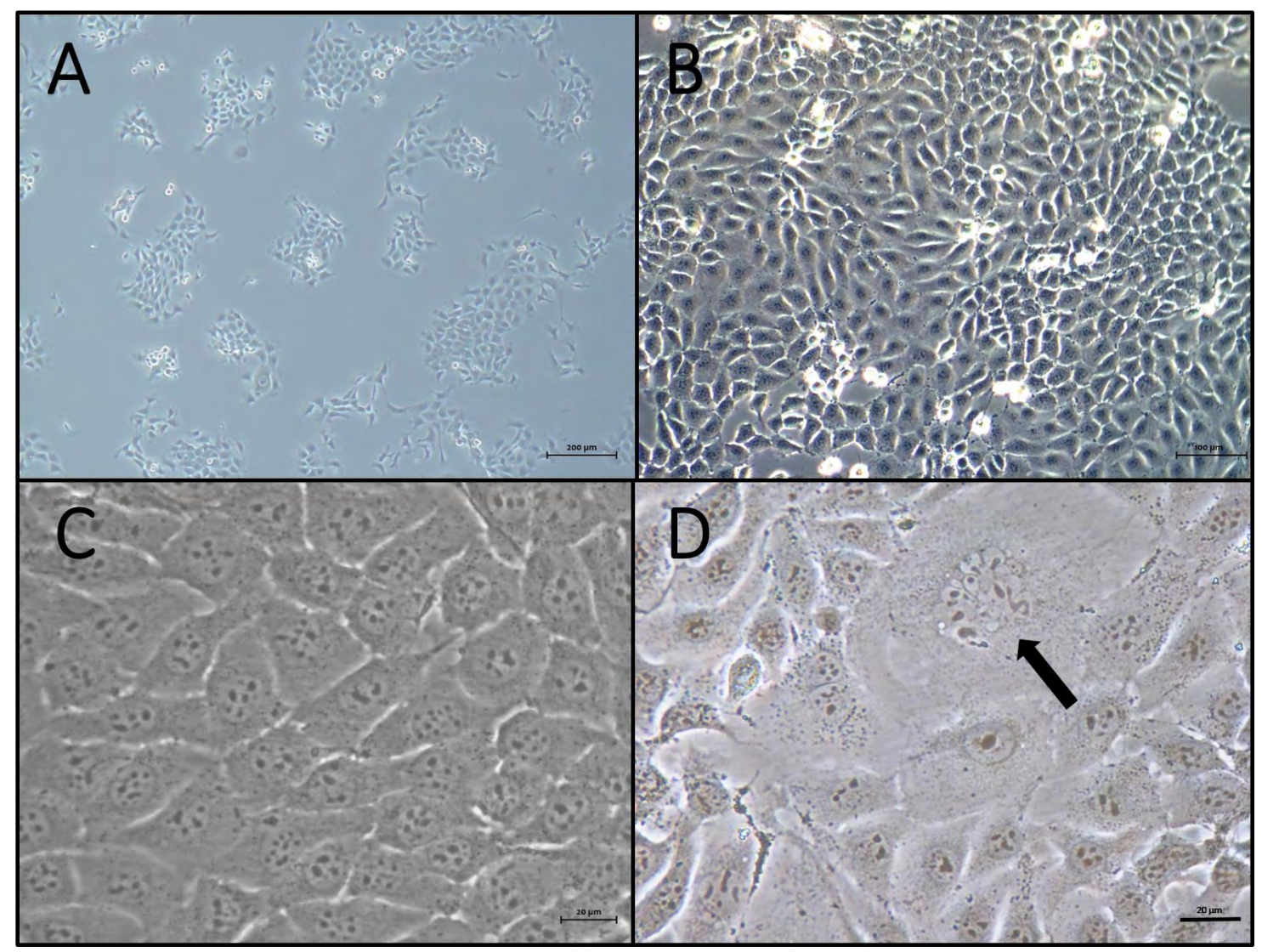

Fonte: XAVIER, P.L.P. 2016.

Legenda: células com morfologia epitelial, apresentando formato poligonal. Núcleos apresentando nucléolos bem definidos. (A) distribuição em monocamada. Pode-se observar a formação de grupos de células justapostas. Aumento de 50X. (B) quando em confluência, as células se organizam na forma de um tapepe, bem semelhante aos tecidos epiteliais. Aumento de 100X. (C) aumento de 400X. (D) a seta aponta uma célula com citoplasma mais amplo do que o normal, apresentando vários núcleos. Aumento de 400X.

- Cultivo CL-28E: Assim como o cultivo anterior, o CL-28E também apresentou morfologia típica de células epiteliais, com formato poligonal, citoplasma pequeno e muitas vezes vacuolizado. Podem ser observados núcleos grandes, com os nucléolos bem evidentes. Algumas células também apresentam citoplasma amplo, com múltiplos núcleos. Em confluência, podia-se observar claramente uma sobreposição das células (Figura 10). 
Figura 10 - Caracterização morfológica do cultivo CL-28E

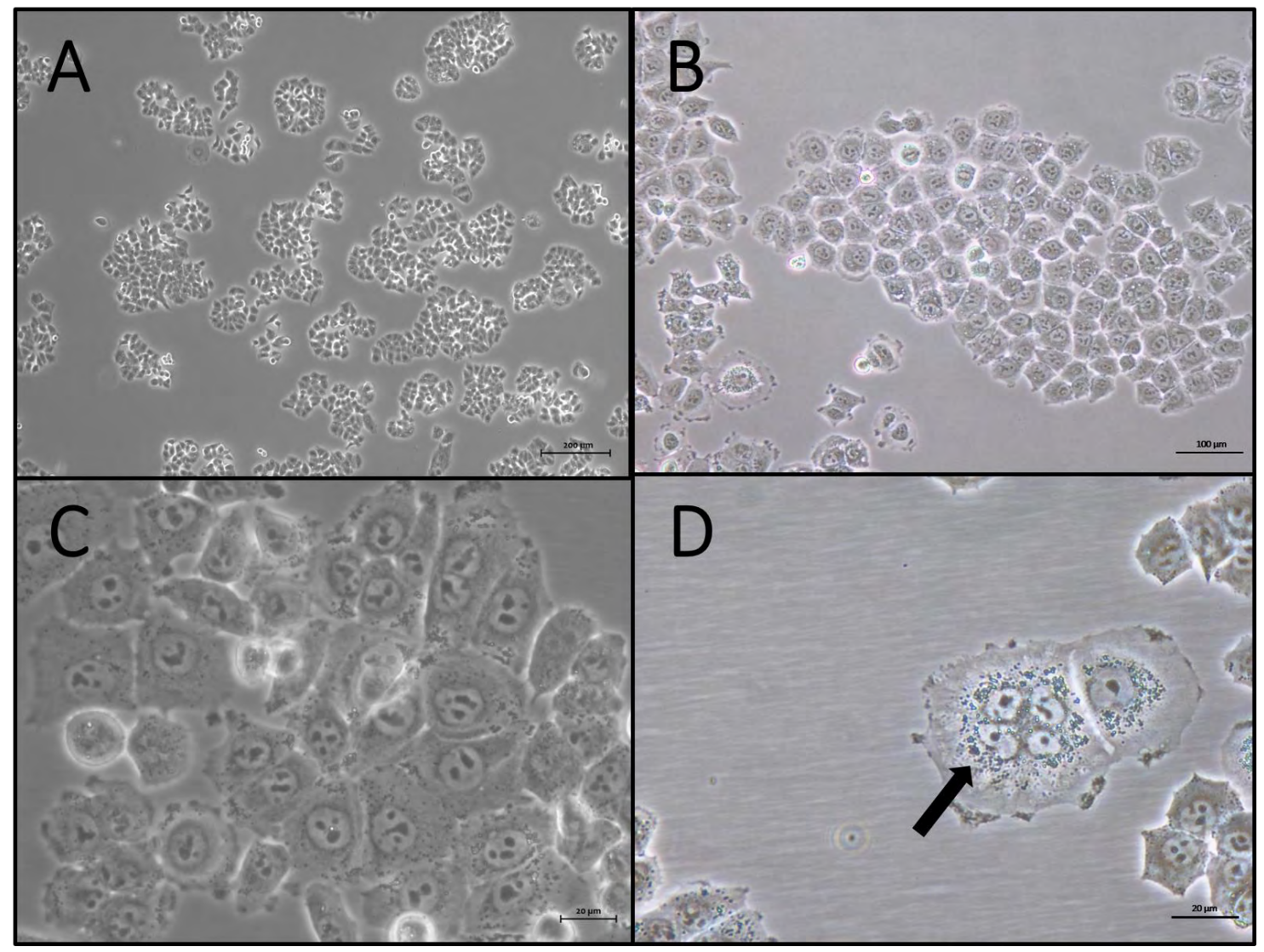

Fonte: XAVIER, P.L.P. 2016.

Legenda: morfologia típica de células epiteliais, com formato poligonal e citoplasma pequeno. Os núcleos são grandes com nucléolos bem evidentes. (A) distribuição em monocamada. Podese observar a formação de grupos de células justapostas. Aumento de 50X. (B) aumento de 100X. (C) aumento de 400X. (D) a seta aponta para a presença de uma célula com o citoplasma mais amplo do que o normal, apresentando vários núcleos. Aumento de 400X.

- Cultivo CB-5M: Diferente dos dois cultivos anteriores, o CB-5M exibiu células com com formato alongado e fusiforme, típico de células fibroblastóides/mesenquimais. $\mathrm{O}$ tamanho dos citoplasmas variou entre as células. A razão entre citoplasma e núcleo era bem aumentada. Os núcleos exibiam nucléolos evidentes e em algumas células apresentavam-se múltiplos. Quando em confluência, podia-se observar a formação de grandes emaranhados de células (Figura 11). 
Figura 11 - Caracterização morfológica do cultivo CB-5M

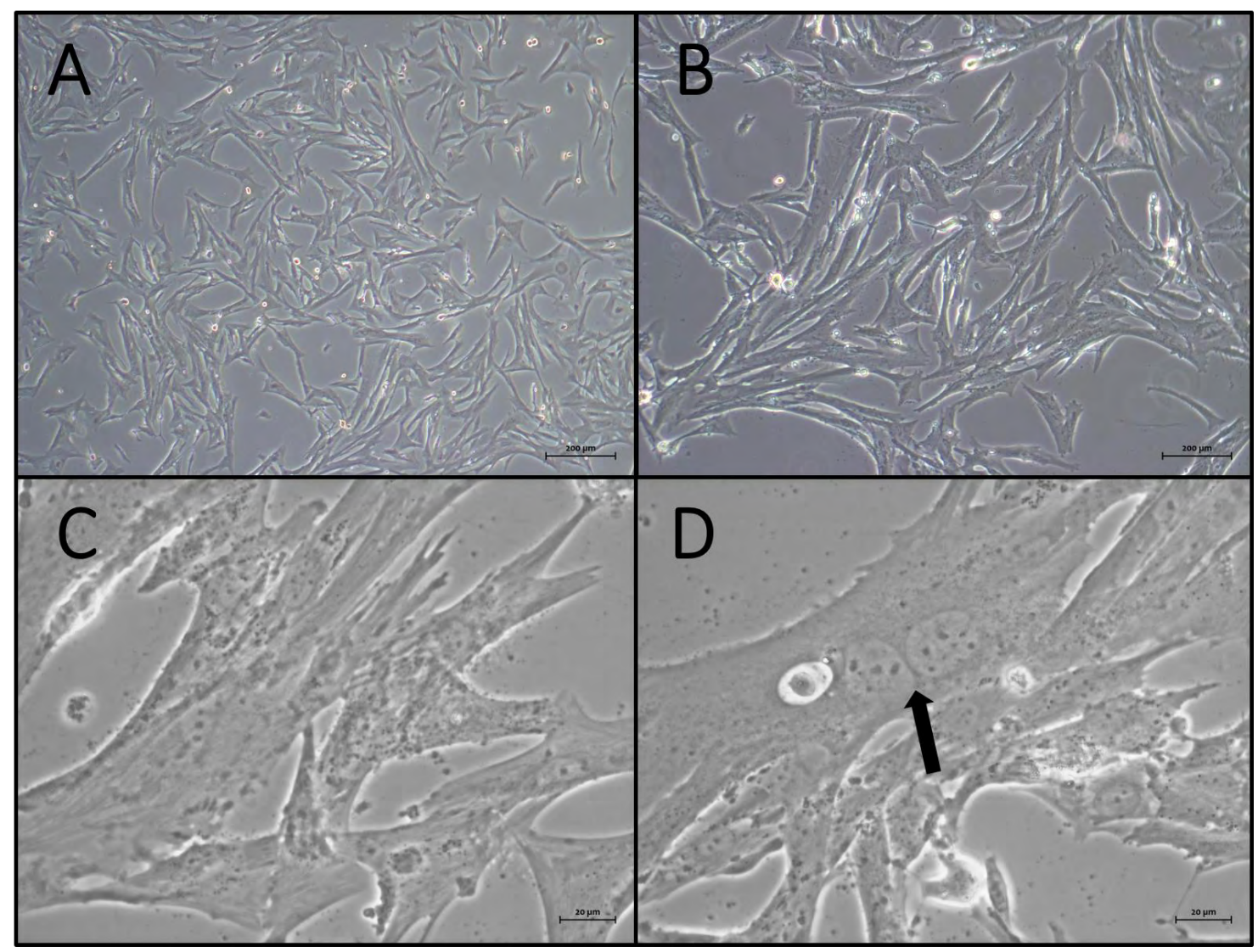

Fonte: XAVIER, P.L.P. 2016.

Legenda: morfologia típica de células mesenquimais, com formato alongado e fusiforme. O citoplasma se apresentou de tamanho variado entre as células, e sua razão em relação ao núcleo era bem aumentada. Os núcleos continham nucléolos bem evidentes. (A) distribuição das células em cultivo. Pode-se observar a formação de um emaranhado de células. Aumento de 50X. (B) aumento de 100X. (C) aumento de 400X. (D) Presença de mais de um núcleo em uma mesma célula. Aumento de 400X.

- Cultivo CL-25M: Assim como CB-5M, o cultivo CL-25M apresentou morfologia característica de células fibroblastóides/mesenquimais, com seu citoplasma alongado e fusiforme e com tamanho variado entre as células. O núcleo também apresentou-se pequeno em relação ao citoplasma e apresentava nucléolos bem evidentes. Em alguns momentos, pode-se observar múltiplos núcleos em uma mesma célula. Quando em confluência, formavam-se grandes emaranhados de células (Figura 12). 
Figura 12 - Caracterização morfológica do cultivo CL-25M

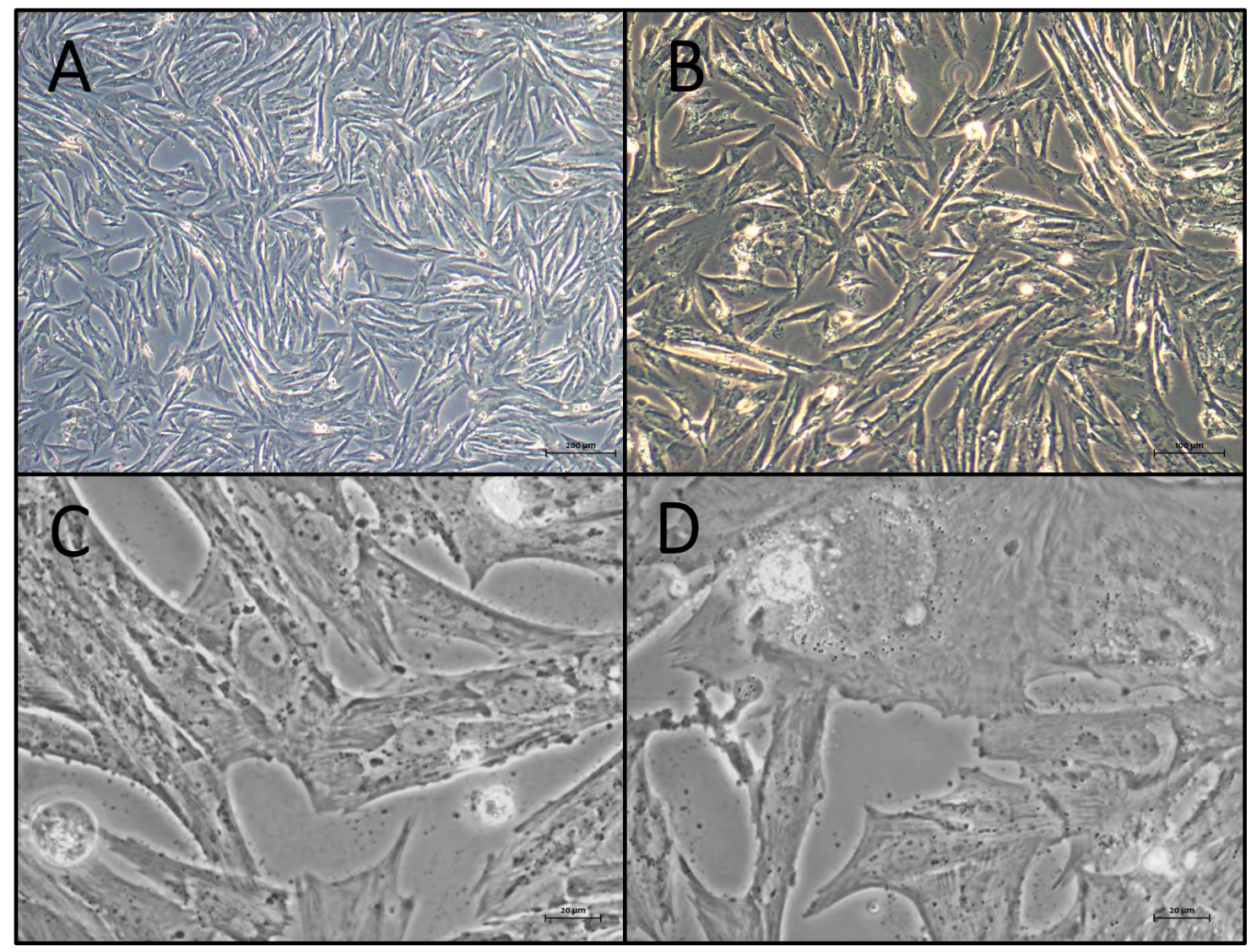

Fonte: XAVIER, P.L.P. 2016

Legenda: células apresentando morfologia mesenquimal, com formato alongado e fusiforme. Os núcleos também se apresentaram pequenos em relação ao citoplasma, com nucléolos bem evidentes. Em confluência, as células formavam grandes emaranhados de células. (A) aumento de 50x. (B) aumento de 100X. (C, D) aumento de 400X.

\subsubsection{Caracterização do citoesqueleto de actina}

Ainda afim de caracterizar os cultivos celulares, foi avaliada a disposição dos filamentos de actina, constituintes do citoesqueleto celular, através do teste de faloidina. De maneira geral, os cultivos celulares apresentavam seus filamentos de actina dispostos de forma desorganizada, característico de células cancerosas. Além disso, os quatro cultivos celulares apresentaram células com projeções dos filamentos de actina, dos tipos lamelipodia e filopodia, as quais são características de células com grande mobilidade e capacidade de migração (MACHESKY, 2008). Nos cultivos celulares CC-20E e CL-28E, também foi observado a presença de pontos agregados de fibras na membrana das células. 
Figura 13 - Caracterização morfológica dos filamentos de actina nos cultivos celulares

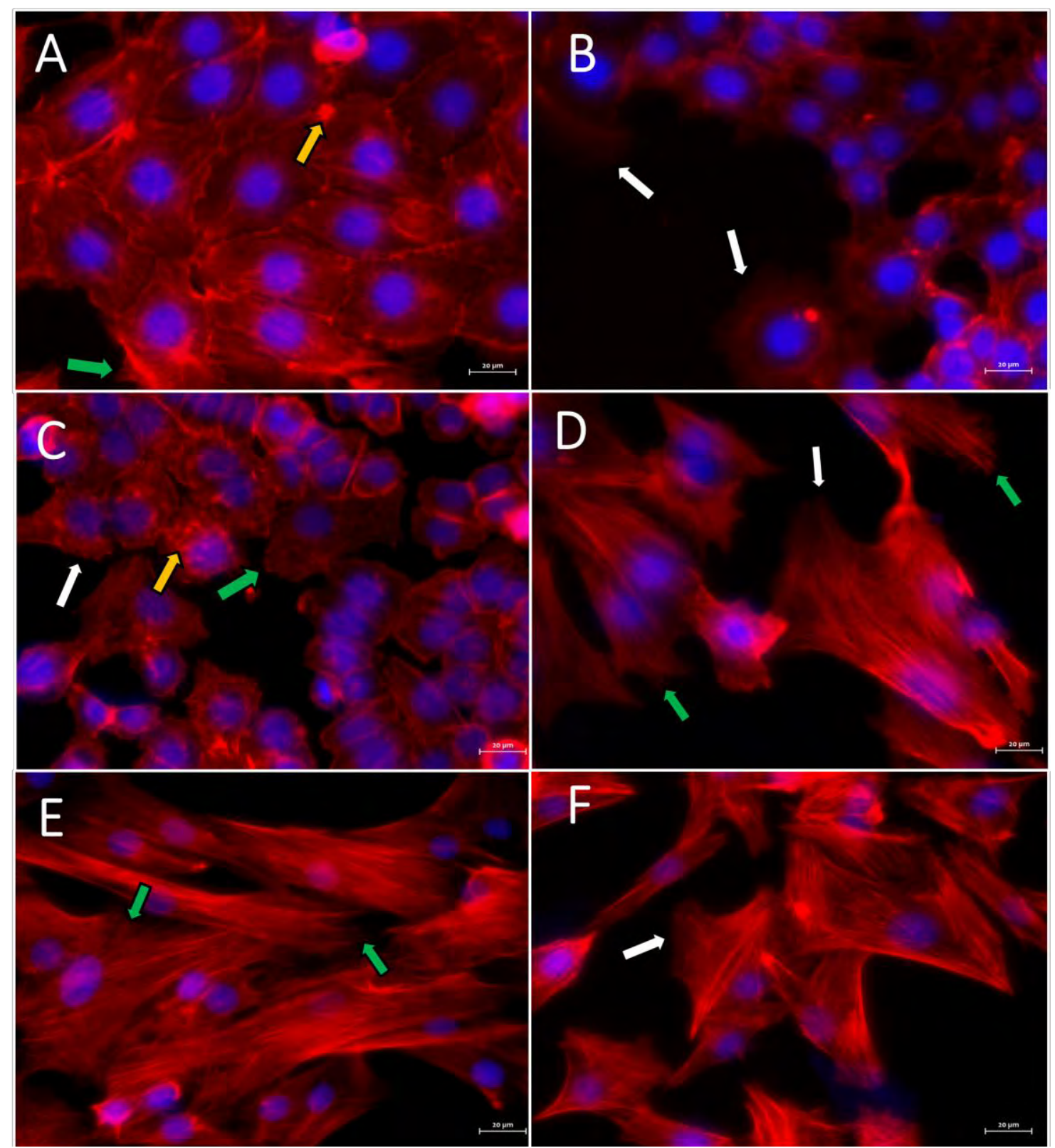

Fonte: XAVIER, P.L.P. 2016

Legenda: pode-se observar a disposição desorganizada dos filamentos de actina em todos os cultivos, característica típica de células cancerosas. Além disso, observa-se a presença de projeções dos filamentos de actina, apontadas pelas setas coloridas. As setas brancas apontam para as projeções do tipo lamelipodia, estruturas que ultrapassam a membrana das células e se projetam para fora. Já as setas verdes correspondem as projeções do tipo filopodia. Nessas, pode-se observar pequenas pontas, que se propagam além das projeções lamelipoides. Por último, as setas amarelas representam pontos agregados de fibras, chamados de invadopodia. Esses estão associados com degradação de matrix extracelular e de proteínas de adesão. (A,B) cultivo CC-20E. Aumento de 400X. (C) cultivo CL-28E. Aumento de 400X. (D) cultivo CB5M. Aumento de 400X. (E,F) cultivo CL-25M. Aumento de 400X. 
Essas estruturas são chamadas de invadopodia, e muitas vezes estão associados com degradação de matriz extracelular e de proteínas de adesão em células invasivas (ECKERT; YANG, 2011) (Figura 13).

\subsubsection{Avaliação da expressão gênica de fatores de transcrição associados a transição epitélio-mesenquimal}

Após caracterizar morfologicamente os quatro cultivos celulares e observar que dois deles, CC-20E e CL-28E, apresentavam fenótipo epitelial, enquanto CB-5M e CL25M exibiam fenótipo mesenquimal, nós decidimos avaliar, por PCR em tempo real, a expressão gênica dos fatores de transcrição SLUG, STAT3, ZEB1 e ZEB2, todos eles associados ao processo de transição epitélio-mesenquimal. Pode-se observar que houve uma grande variação na expressão desses genes entre os cultivos. Com exceção de ZEB2, todos os outros genes avaliados foram mais expressos nos cultivos CB-5M e CL-25M, caracterizados morfologicamente como mesenquimais, em relação aos cultivos CC-20E e CL-28E, caracterizados morfologicamente como epiteliais (Gráfico 2). 
Gráfico 2 - Expressão gênica relativa dos fatores de transcrição SLUG, STAT3, ZEB1 e ZEB2 nos cultivos celulares
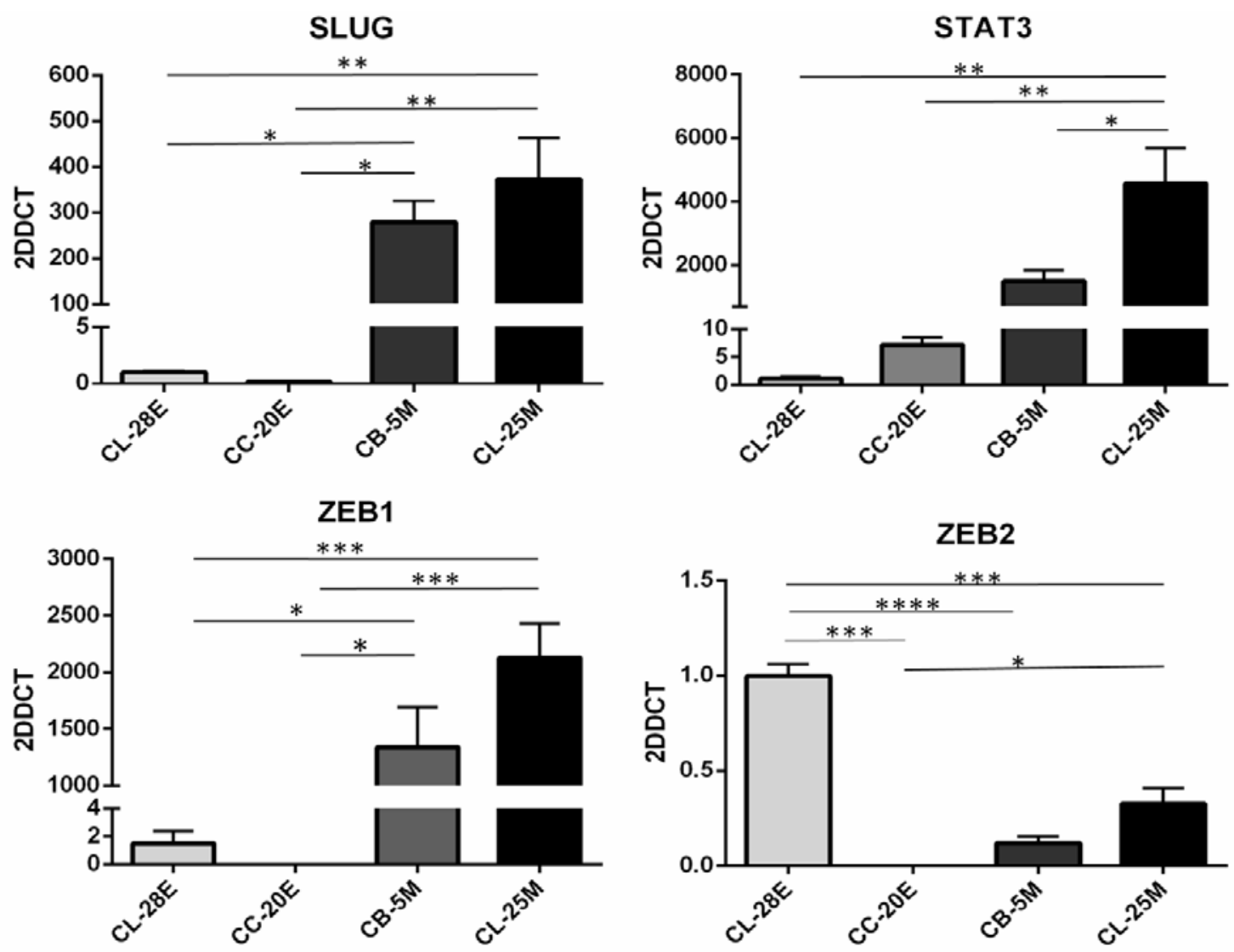

Fonte: XAVIER, P.L.P. 2016

Legenda: os fatores de transcrição SLUG, STAT3 e ZEB1 apresentaram maiores níveis significantes de expressão nos cultivos CB-5M e CL-25M, caracterizados como mesenquimais. Já o fator de transcrição ZEB2, apresentou maior expressão no cultivo CL-28E. Teste ANOVA de uma via $(* \mathrm{p}<0,05 ; * * \mathrm{p}<0,01 ; * * * \mathrm{p}<0,001 ; * * * * \mathrm{p}<0,0001)$

\subsubsection{Avaliação do potencial de invasão dos cultivos celulares}

A maior expressão de fatores de transcrição associados a transição epitélio mesenquimal é muitas vezes associada com a maior capacidade de invasão das células. Sendo assim, foi realizado o ensaio de invasão utilizando insertos transwell preenchidos com gel ECM, a fim de avaliar se há correlação entre a expressão dos fatores de transcrição e a capacidade de invasão dos nossos cultivos. Curiosamente, o cultivo CC20E que apresentou baixos níveis de expressão de todos os fatores de transcrição avaliados, revelou-se com maior potencial de degradação do gel ECM e invasão do inserto (Figura 14; gráfico 3). Sendo assim, não houve correlação entre os níveis de 
expressão gênica dos fatores de transcrição e a capacidade de invasão dos cultivos celulares.

Figura 14 - Capacidade de invasão dos cultivos celulares em insertos transwell

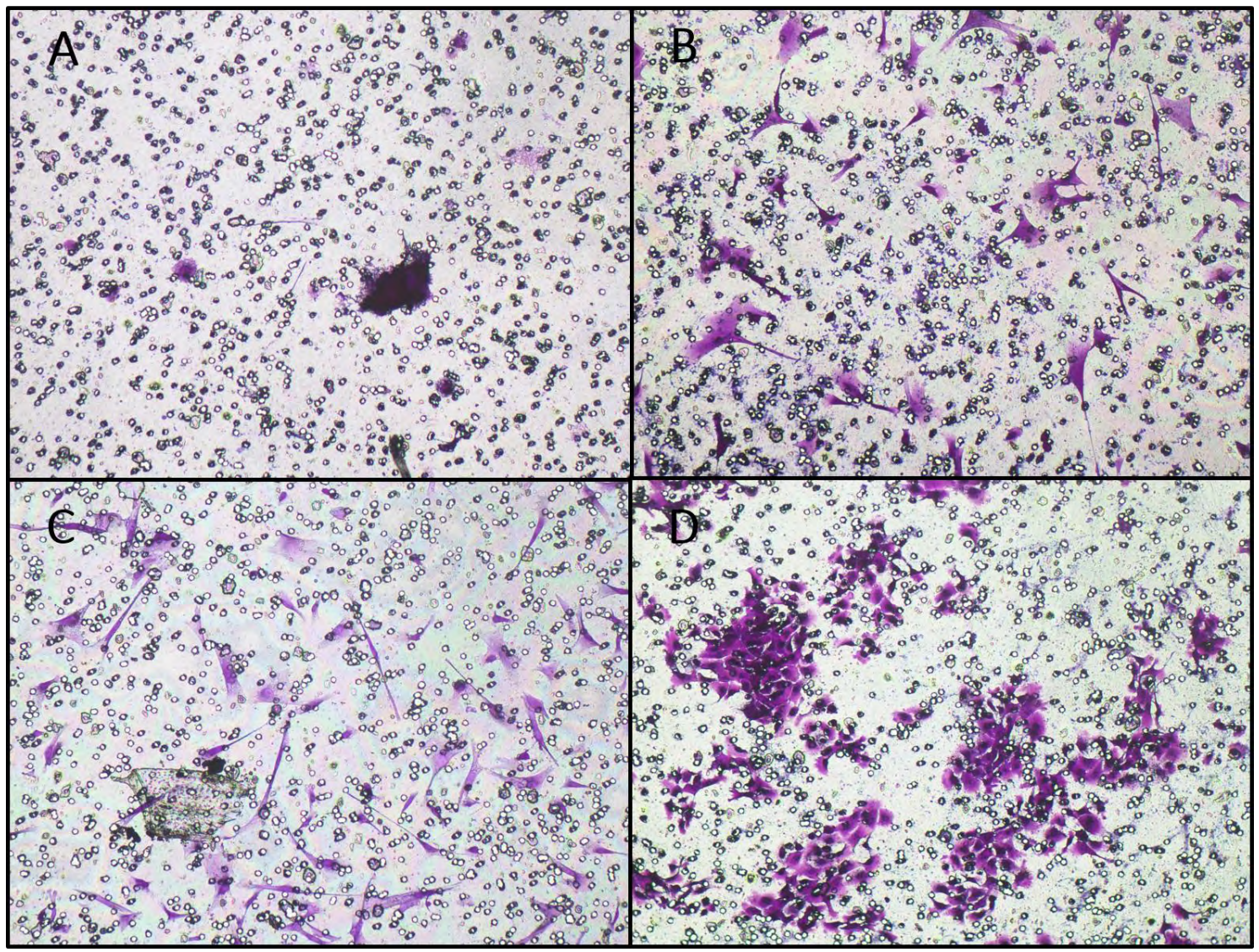

Fonte: XAVIER, P.L.P. 2016

Legenda: as células do cultivo CC-20E (D), apresentaram maior capacidade de degradação do gel ECM e invasão dos insertos em relação aos cultivos CL-28E (A), CB-5M (B) e CL-25M (C). Imagens capturadas em aumento de 100X. 
Gráfico 3 - Capacidade de invasão dos cultivos celulares em insertos transwell

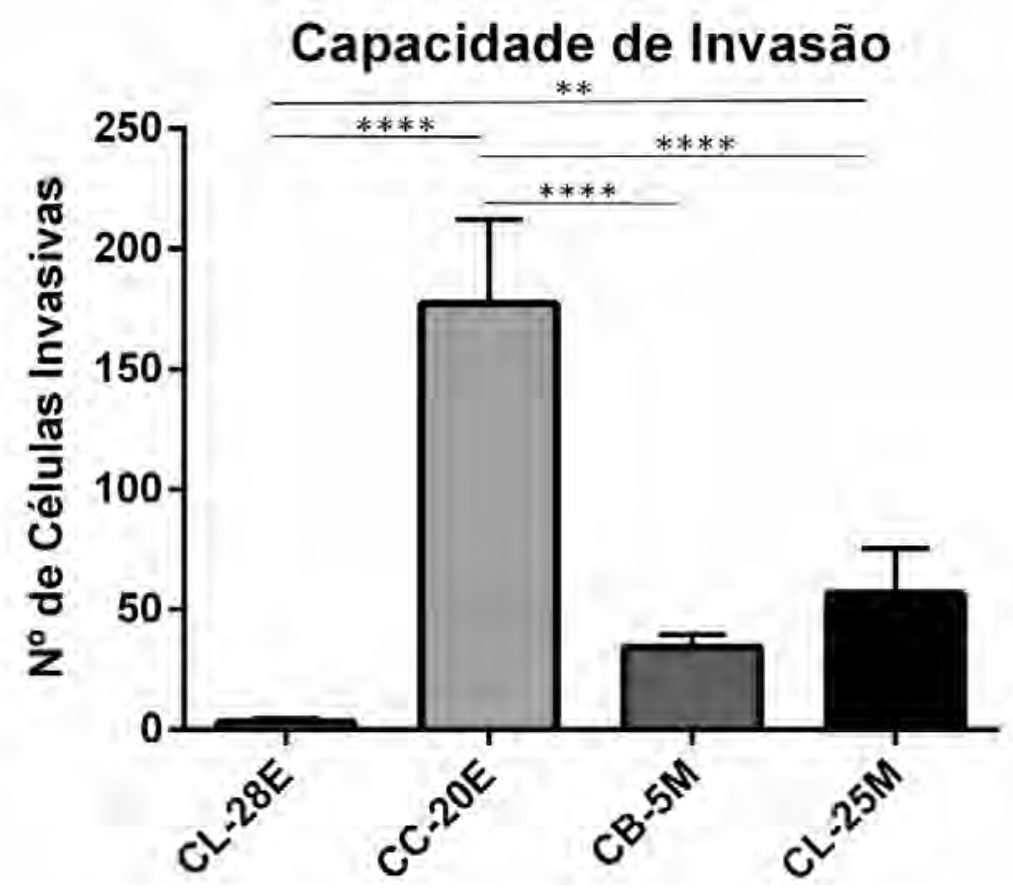

Fonte: XAVIER, P.L.P. 2016

Legenda: células do cultivo CC-20E apresentaram maior número de células invasivas contadas por campo em insertos transwell, em relação aos outros cultivos celulares. Teste ANOVA de uma via $(* * \mathrm{p}<0,01 ; * * * \mathrm{p}<0,001 ; * * * * \mathrm{p}<0,0001)$

\subsection{EXPERIMENTO 2: EXPRESSÃO EXÓGENA DOS FATORES DE} TRANSCRIÇÃO SLUG E ZEB1 NOS CULTIVOS DE CÉLULAS CC-20E E CL-28E

\section{E A CARACTERIZAÇÃO DE SEUS EFEITOS IN VITRO}

Uma vez que as células CC-20E e CL-28E apresentaram fenótipo de células epiteliais, além dos menores níveis de expressão gênica para os fatores de transcrição estudados, nós as selecionamos para serem utilizadas no próximo experimento, no qual foi objetivado a expressão exógena dos fatores de transcrição SLUG e ZEB1 nessas células, afim de induzir o processo de transição epitélio-mesenquimal e caracterizar seus possíveis efeitos in vitro. 


\subsubsection{Transdução lentiviral e validação da expressão exógena de SLUG e ZEB1}

Afim de induzir a expressão exógena dos fatores de transcrição SLUG e ZEB1 de forma estável, células dos cultivos CC-20E e CL-28E foram infectadas com partículas lentivirais contendo os plasmídeos FUGW-SLUG, FUGW-ZEB1 e FUGW-eGFP, o qual foi utilizado como controle positivo. Após 72 horas de infecção, as células foram observadas por microscopia de fluorescência, para determinar o sucesso da transdução através da visualização de células verdes, ou seja, positivas para GFP. Entretanto, em um primeiro instante, apenas as células transduzidas com o plasmídeo controle FUGW-eGFP, apresentaram positividade para eGFP por microscopia de fluorescência (Figura 15), provavelmente devido à baixa eficiência de transdução dos plasmídeos contendo as ORFs de SLUG e ZEB1. 
Figura 15 - Detecção das células positivas para eGFP por microscopia de fluorescência nos cultivos epiteliais controle, SLUG e ZEB1

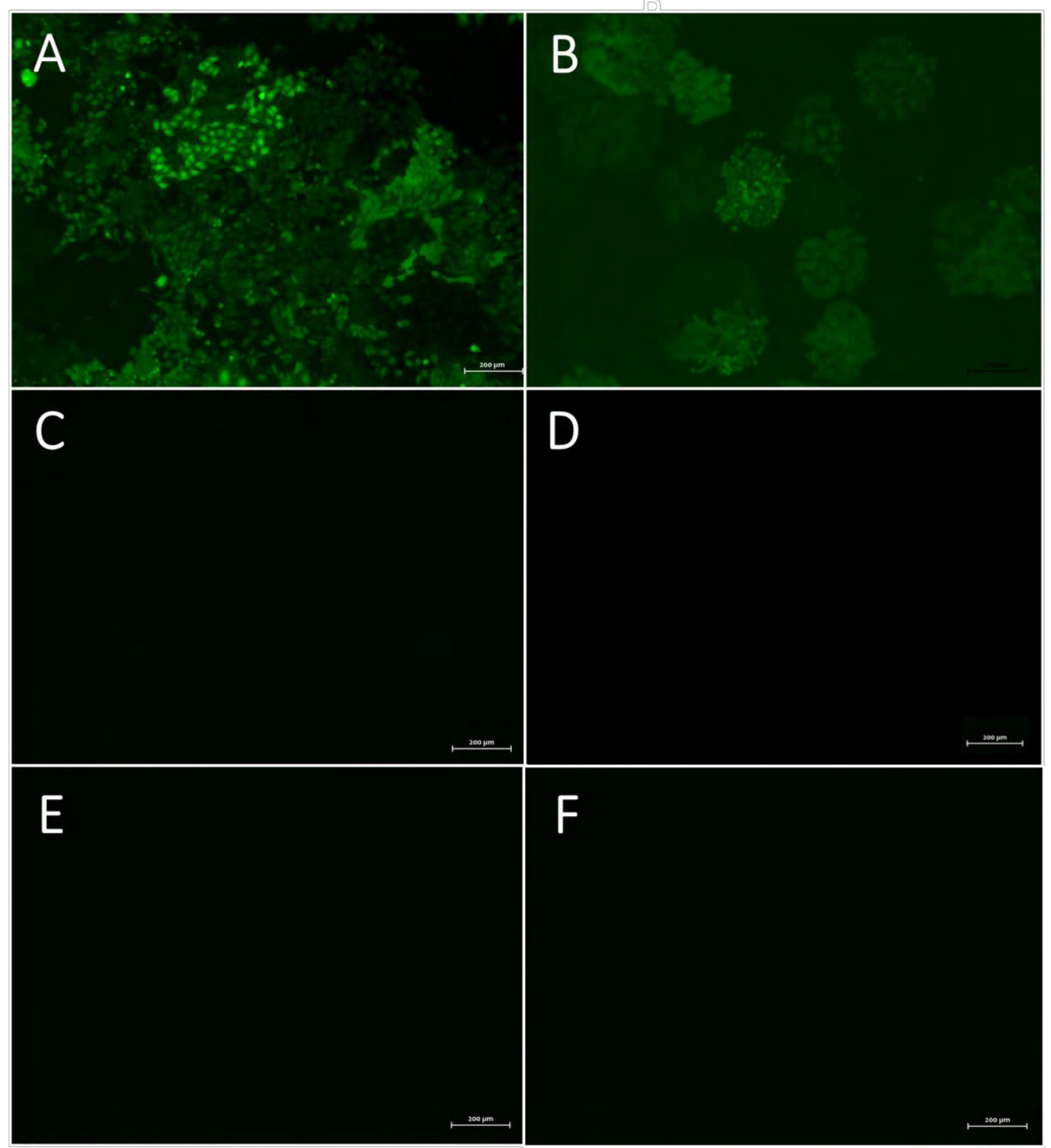

Fonte: XAVIER, P.L.P. 2016

Legenda: após transdução, apenas as células transduzidas com o plasmídeo controle FUGWeGFP apresentaram expressão de eGFP no microscópio de fluorescência. (A,B) CC20Econtrole e CL-28Econtrole. Aumento de 50X. Nenhuma célula positiva para eGFP foi detectada nos cultivos transduzidos com os plasmídeos FUGW-SLUG e FUGW-ZEB1. (C,D) CC-20Eslug e CL-28Eslug. Aumento de 50X. (E,F) CC-20Ezeb1 e CL-28Ezeb1. 
Afim de confirmar a expressão dos fatores de transcrição SLUG e ZEB1 nos cultivos, foram realizadas novas análises de expressão gênica por PCR em tempo real. Os resultados confirmaram a expressão de SLUG tanto no cultivo CC-20E, quanto no cultivo CL-28E (Gráfico 4 e tabela 4). Entretanto, não houve expressão de ZEB1 em nenhum dos cultivos. Sendo assim, apenas as células transduzidas com o plasmídeo FUGW-SLUG foram utilizadas nas próximas etapas do experimento.

Gráfico 4 - Avaliação da expressão gênica de SLUG entre os cultivos transduzidos com o plasmídeo controle e os cultivos transduzidos com o plasmídeo FUGW-SLUG.

\section{SLUG}

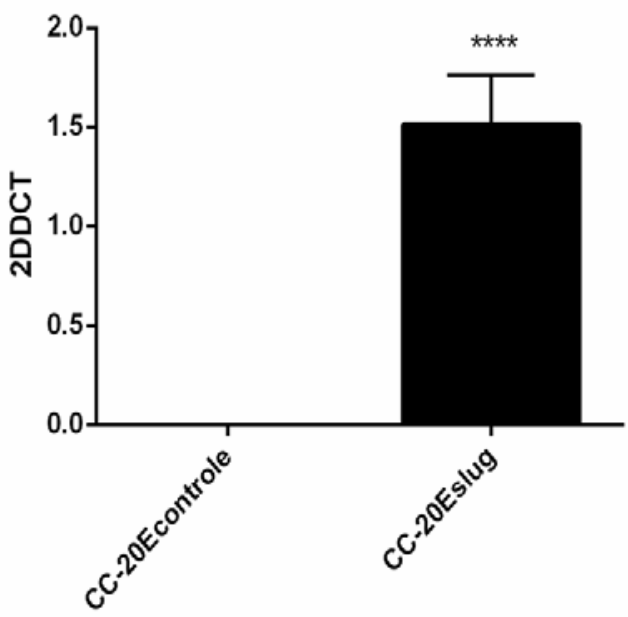

SLUG

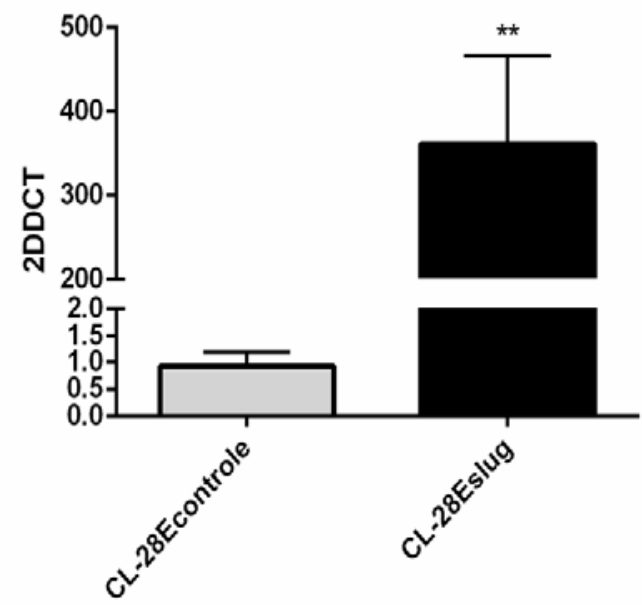

Fonte: XAVIER, P.L.P. 2016

Legenda: comparação da expressão gênica de SLUG entre os cultivos controle e SLUG. Como esperado, os resultados confirmaram a superexpressão do fator de transcrição SLUG nas células transduzidas com o plasmídeo FUGW-SLUG. Teste T paramétrico de Student (****p $<0,0001)$. Teste não paramétrico de Mann-Whitney $(* * p=0,0079)$. 
Tabela 3 - Avaliação da expressão gênica de SLUG entre as células controle e com superexpressão de SLUG

\begin{tabular}{|c|c|c|c|c|}
\hline Células & CT 18s & CT SLUG & $\begin{array}{c}\Delta \mathrm{CT}(\mathrm{CT} \\
\mathrm{SLUG}-\mathrm{CT} \\
\mathbf{1 8 s})\end{array}$ & $2 \Delta \Delta C T$ \\
\hline $\begin{array}{c}\text { CC- } \\
\text { 20Econtrole }\end{array}$ & $8,78 \pm 0,44$ & 0 & 0 & 0 \\
\hline CC-20Eslug & $8,50 \pm 0,36$ & $21,82 \pm 1,30$ & $13,32 \pm 1,43$ & $1,51 \pm 0,25$ \\
\hline $\begin{array}{c}\text { CL- } \\
\text { 28Econtrole }\end{array}$ & $9,50 \pm 0,30$ & $29,77 \pm 0,72$ & $20,26 \pm 0,61$ & $0,92 \pm 0,25$ \\
\hline CL-28Eslug & $9,01 \pm 0,18$ & $20,95 \pm 0,39$ & $11,94 \pm 0,47$ & $361,31 \pm 104,91$ \\
\hline
\end{tabular}

Fonte: XAVIER, P.L.P. 2016

Legenda: os valores de CT, correspondem ao ciclo de amplificação dos genes 18s (endógeno) e SLUG (alvo) nas células. Os valores de $\triangle \mathrm{CT}$ correspondem aos valores de CT do gene alvo subtraídos dos valores de CT do gene endógeno. Os valores de $2 \Delta \Delta \mathrm{CT}$ foram calculados de acordo com LIVAK \& SCHMITTGEN, 2001. Valores em zero, significam que nenhuma expressão do gene foi detectada. Todos os valores são descritos em média e desvio padrão.

\subsubsection{Enriquecimento das células positivas para eGFP}

Afim de selecionar apenas as células positivas para eGFP, que correspondem as células com expressão forçada de SLUG, foram realizados dois ciclos de enriquecimento por citometria de fluxo. Devido a maior potência do laser utilizado pelo citômetro de fluxo em relação ao microscópio de fluorescência, uma pequena população de células positivas para eGFP foi detectada entre as células CC-20E e CL-28E transduzidas com FUGW-SLUG e FUGW-ZEB1. Essas foram então submetidas a análise e separação, selecionadas e cultivadas novamente sob as mesmas condições. Após o primeiro enriquecimento, os cultivos CC-20Eslug e CL-28Eslug apresentaram células positivas para eGFP, porém em uma intensidade menor em relação as células controle CC-20Efugw e CL-28Efugw (Figura 16). Devido a pequena população de células detectadas no primeiro enriquecimento, um segundo enriquecimento foi realizado. Nesse, uma população maior de células positivas para eGFP foi detectada, e essas foram selecionadas para as próximas etapas do experimento (Figura 16). 
Figura 16 - Detecção das células positivas para eGFP por microscopia de fluorescência nos cultivos CC-20Eslug e CL-28Eslug após enriquecimento por citometria de fluxo

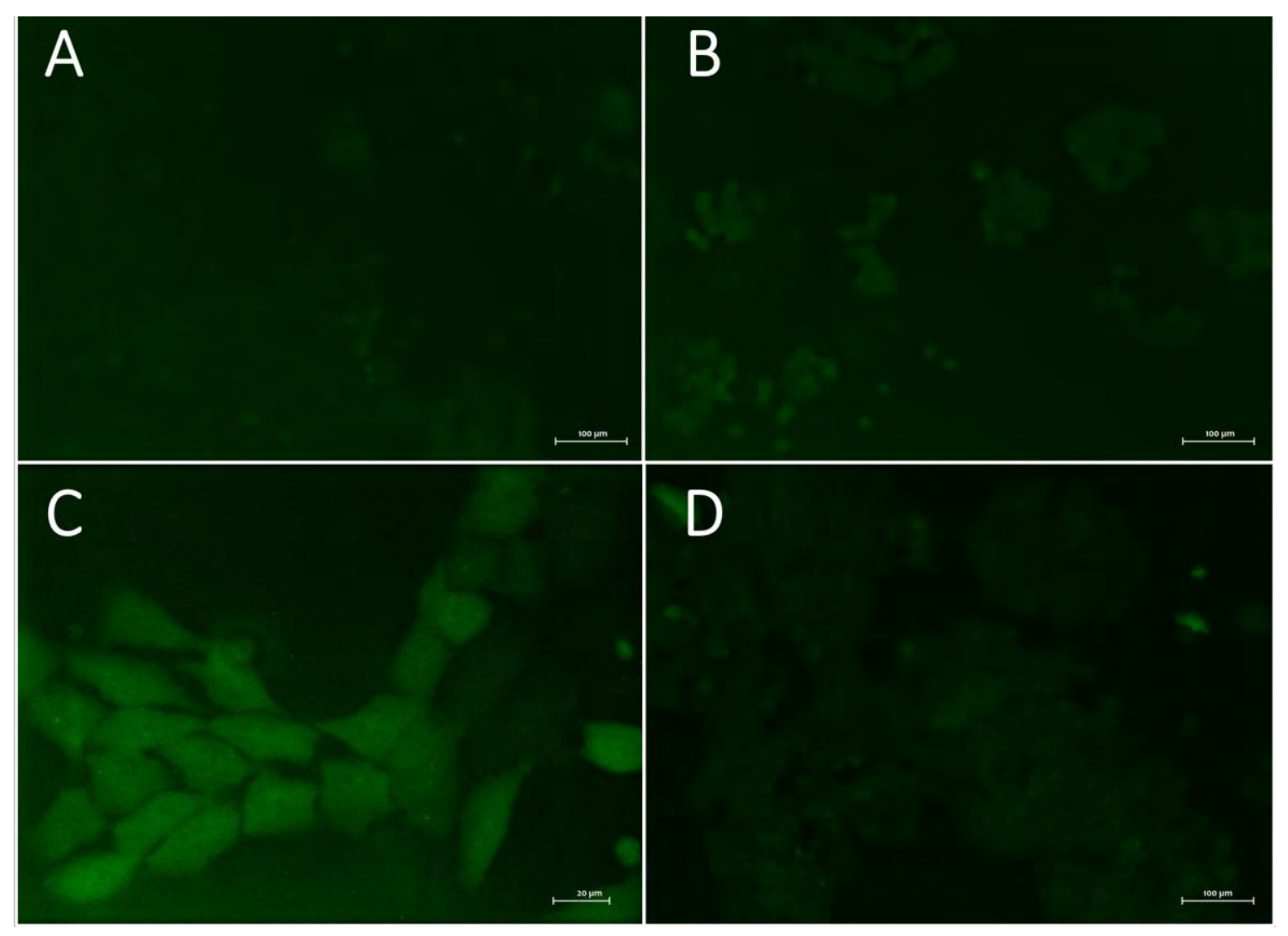

Fonte: XAVIER, P.L.P. 2016

Legenda: detecção das células positivas para eGFP por microscopia de fluorescência. (A,B) células do cultivo CC-20Eslug e CL-28Eslug, respectivamente, após o primeiro enriquecimento por citometria de fluxo. Aumento de 100X. (C,D) células do cultivo CC20Eslug e CL-28Eslug, respectivamente, após o segundo ciclo de enriquecimento. Aumento de 400X e 100X.

\subsubsection{Caracterização morfológica das células controle e com superexpressão de SLUG}

A expressão de SLUG pode induzir ao processo de transição epitéliomesenquimal, alterando a morfologia das células e modificando o padrão de expressão de filamentos intermediários como citoqueratina, vimentina e actina. As células epiteliais controle e SLUG foram, primeiramente, comparadas quanto sua morfologia, por microscopia óptica. Em relação aos cultivos CC-20Econtrole e CC-20Eslug, nenhuma diferença aparente foi notada (Figura 17). 
Figura 17 - Caracterização morfológica dos cultivos CC-20Econtrole e CC-20Eslug

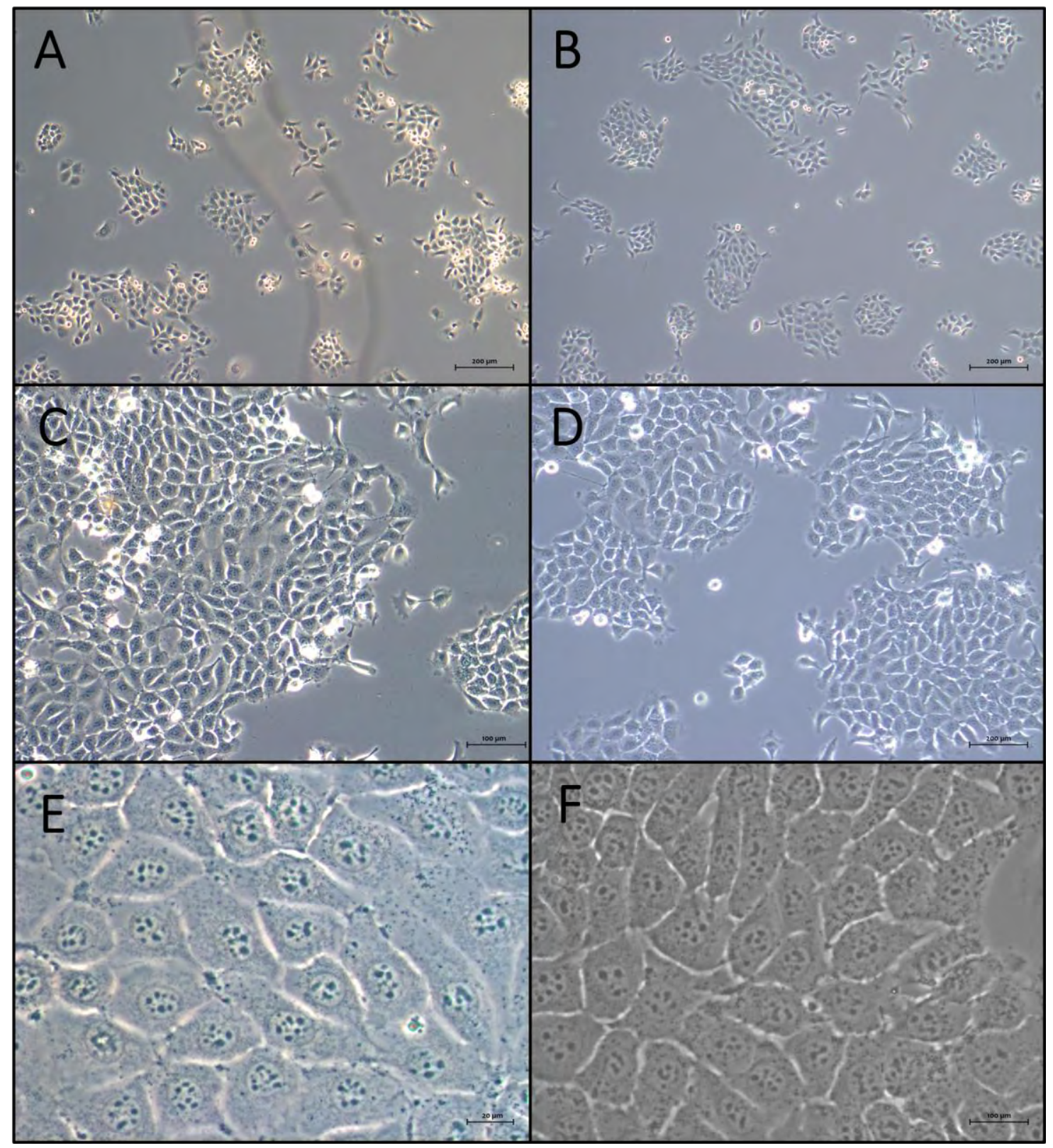

Fonte: XAVIER, P.L.P. 2016

Legenda: caracterização morfológica dos cultivos CC-20Econtrole e CC-20Eslug. Nenhuma diferença aparente foi observada entre os cultivos. (A,C,E) caracterização morfológica do cultivo CC-20Econtrole. Aumentos de 50X, 100X e 400X, respectivamente. (B,D,F) Caracterização morfológica do cultivo CC-20Eslug. Aumentos de 50X, 100X e 400X, respectivamente.

Entretanto, em relação aos cultivos CL-28Econtrole e CC-28Eslug, algumas diferenças foram observadas. Quando atingiam cerca de 50\% de confluência, as células CC-28Eslug pareciam achatar seu citoesqueleto, diminuindo de tamanho. Além disso, 
pode-se observar a formação de colônias de células, que se assemelham a tubulos semidiferenciados, estrutura característica de carcinomas mamários (Figura 18).

Figura 18 - Caracterização morfológica dos cultivos CL-28Econtrole e CL-28Eslug

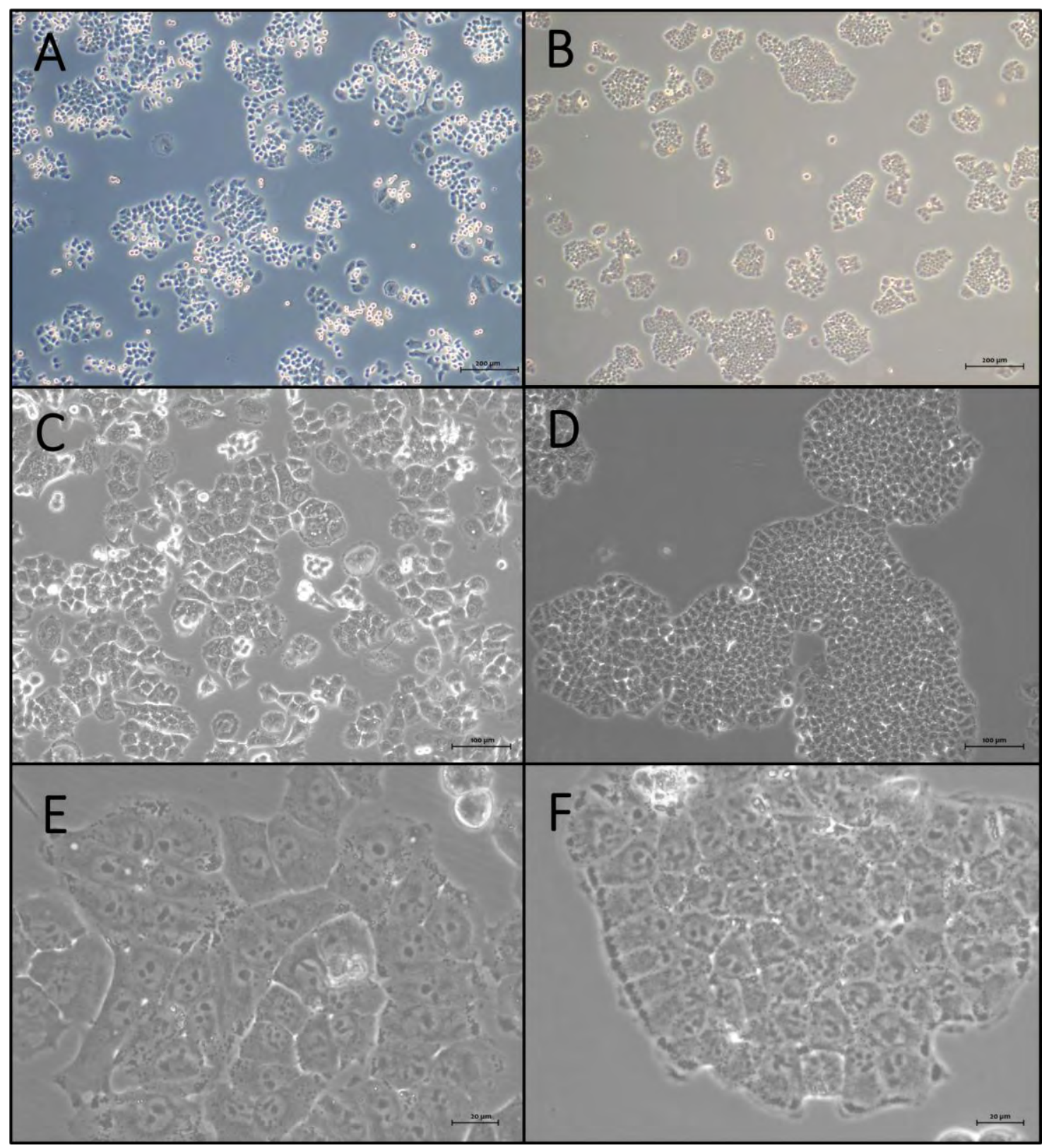

Fonte: XAVIER, P.L.P. 2016

Legenda: caracterização morfológica dos cultivos CL-28Econtrole e CL-28Eslug. Após a expressão exógena de SLUG, as células achataram seu citoplasma e se distribuíram de maneira diferente, formando colônias muito semelhantes a túbulos semidiferenciados. (A,C,E) caracterização morfológica do cultivo CL-28Econtrole. Aumentos de 50X, 100X e 400X, respectivamente. $(\mathrm{B}, \mathrm{D}, \mathrm{F})$ caracterização morfológica do cultivo CL-28Eslug. Aumentos de 50X, 100X e 400X, respectivamente. 
O padrão de expressão de filamentos intermediários também foi analisado por imunocitoquímica. As células CC-20Econtrole e CC-20slug não apresentaram diferença quanto a marcação do filamento citoqueratina, sendo que em ambas este filamento foi expresso de maneira homogênea e com intensidade de marcação considerada média. Entretanto, em relação ao filamento vimentina, houve um aumento da intensidade de marcação nas células CC-20Eslug, em relação a CC-20Econtrole. A marcação pode ser observada com intensidade média e de forma homogênea nas células, observada principalmente entre as junções intercelulares (Figura 19).

Figura 19 - Marcação imunocitoquímica para expressão de citoqueratina e vimentina nas células CC-20Econtrole e CC-20Eslug

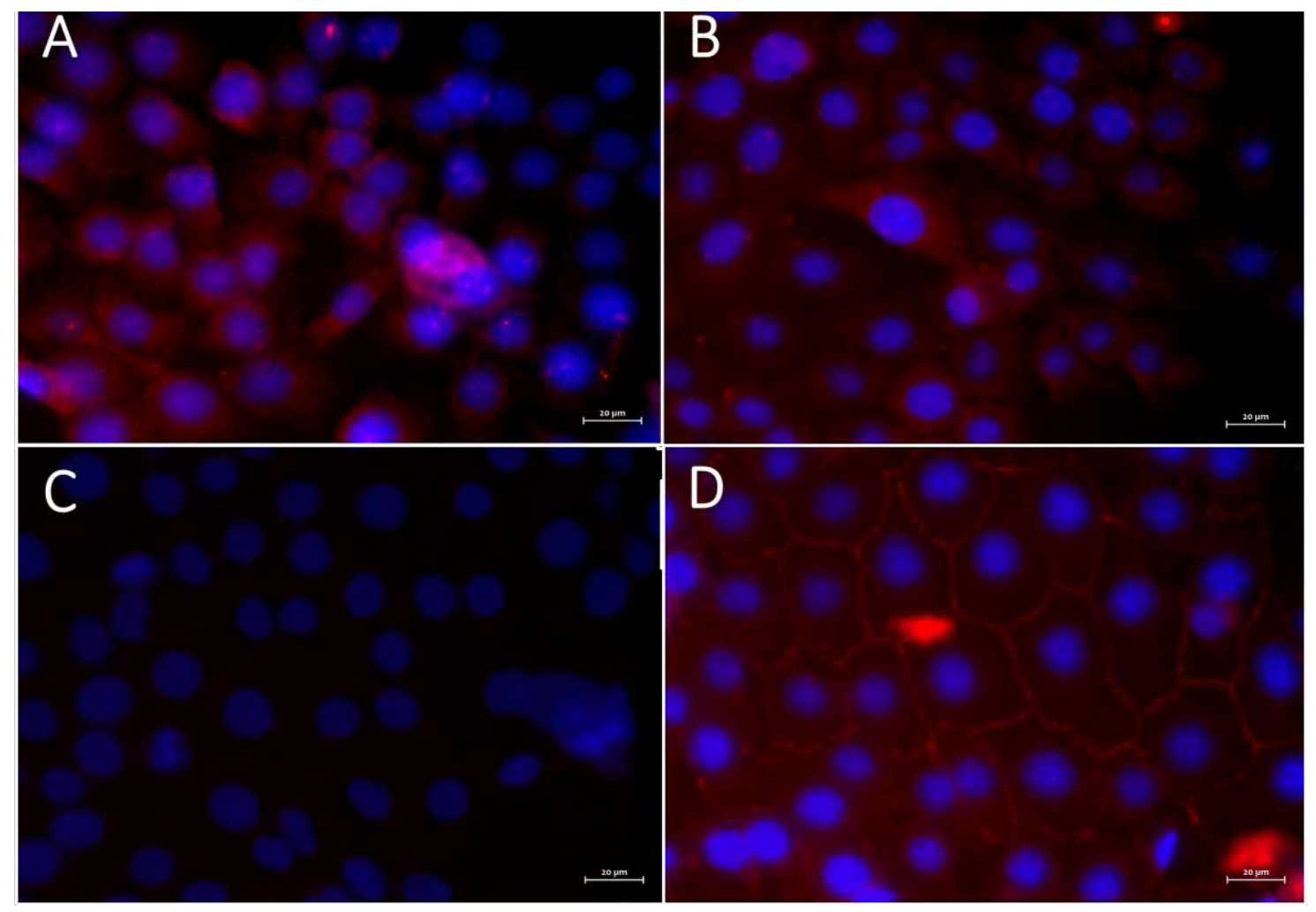

Fonte: XAVIER, P.L.P. 2016

Legenda: (A,B) expressão de citoqueratina nas células CC-20Econtrole e CC-20Eslug, respectivamente. Não foi observada diferença na expressão desse filamento intermediário entre as células. (C,D) expressão de vimentina nas células CC-20Econtrole e CC-20Eslug, respectivamente. Nota-se o aumento da expressão de vimentina nas células com superexpressão para SLUG. (A,B,C,D) Aumento de 400x.

Quanto aos cultivos CL-28Econtrole e CL-28Eslug, pode-se observar diferenças de expressão do filamento intermediário citoqueratina. Nas células CL-28Econtrole, a marcação pode ser observada de forma heterogênea, com algumas células apresentando 
marcação intensa do filamento, enquanto outras apresentaram marcação média e fraca. Já nas células que apresentavam expressão exógena de SLUG, a expressão de citoqueratina foi homogênea entre as células, porém apresentando menor intensidade de marcação. Quanto ao filamento vimentina, tanto as células controle quanto as células com expressão exógena de SLUG, apresentaram marcação heterogênea, com algumas células apresentando intensidade média de marcação e outras apresentando intensidade fraca. Os filamentos de vimentina nessas células foram observados principalmente próximos e ao redor do núcleo das células (Figura 20).

Figura 20 - Marcação imunocitoquímica para expressão de citoqueratina e vimentina nos cultivos CL-28Econtrole e CL-28Eslug

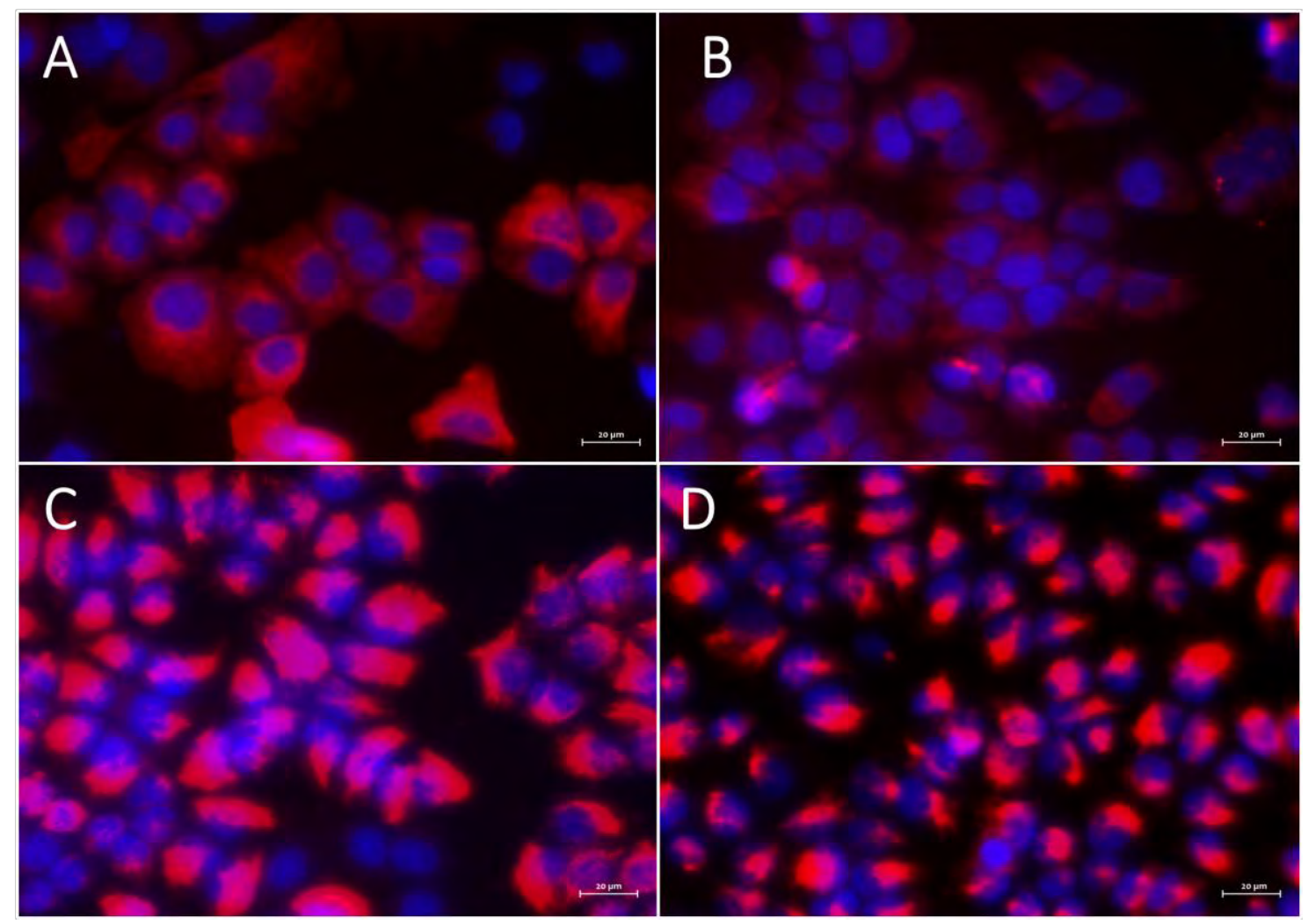

Fonte: XAVIER, P. L. P. 2016

Legenda: (A,B) expressão de citoqueratina nas células CL-28Econtrole e CL-28Eslug respectivamente. Pode-se notar diminuição da expressão de citoqueratina nas células com expressão exógena de SLUG. (C,D) expressão de vimentina nas células CL-28Econtrole e CL28Eslug. Não foi observada diferença de expressão desse filamento entre as células. (A,B,C,D) Aumento de 400x. 
A disposição dos filamentos de actina também foi avaliada nas células com expressão exógena de SLUG, em relação as células controle, sendo que nenhuma diferença foi observada entre as células. Tanto as células controle quanto as células modificadas apresentaram a mesma disposição desorganizada dos filamentos de actina, e como já citado anteriormente, foram observadas projeções dos tipos lamelipodia, filopodia e invadopodia dos filamentos de actina (Figura 21).

Figura 21 - Caracterização morfológica dos filamentos de actina nos cultivos controle e com expressão exógena de SLUG

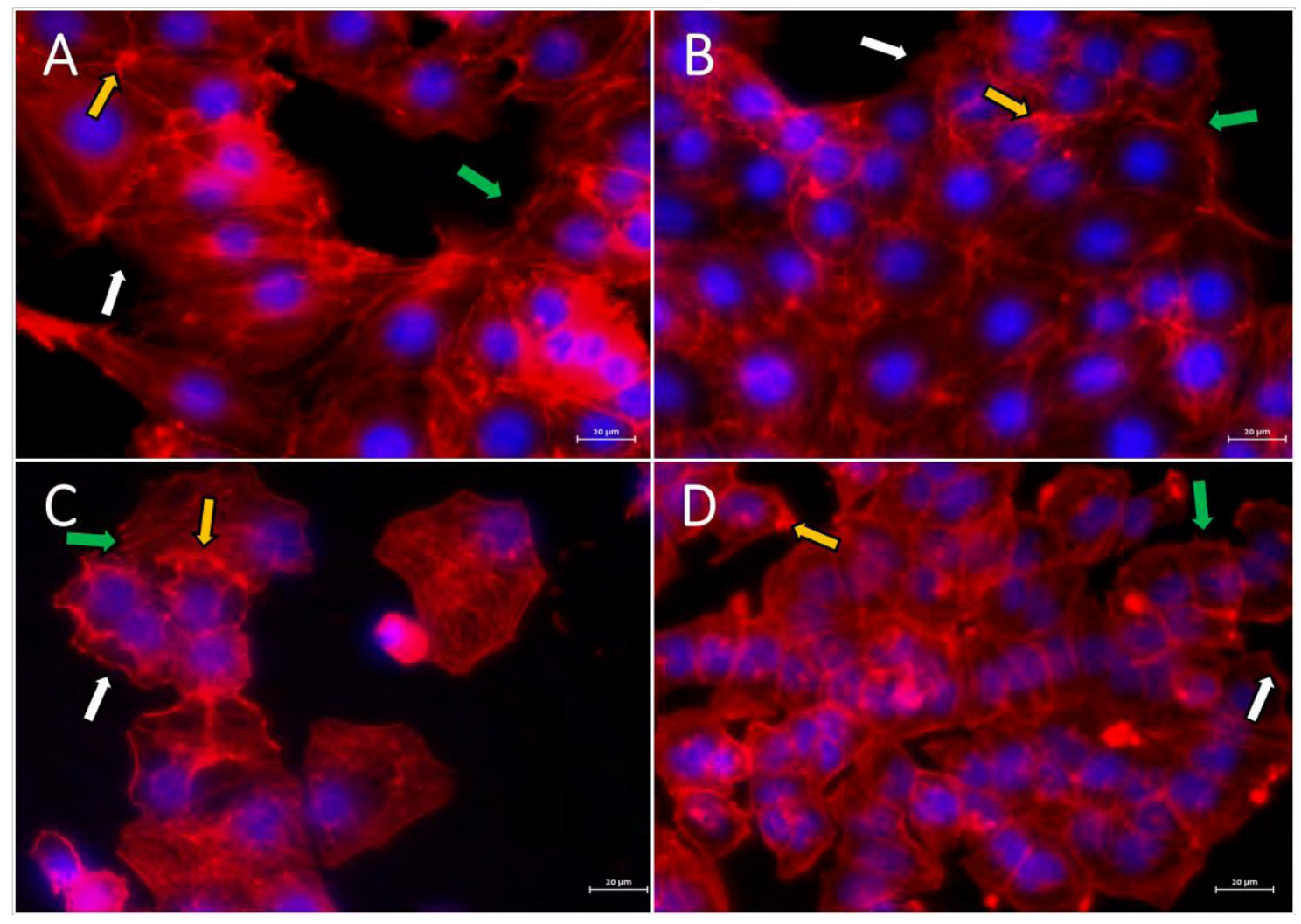

Fonte: XAVIER, P.L.P. 2016

Legenda: disposição desorganizada dos filamentos de actina tanto nas células controle, quanto nas células com expressão forçada de SLUG. Observa-se a presença de projeções dos filamentos de actina, apontadas pelas setas coloridas. As setas brancas apontam para as projeções do tipo lamelipodia. Já as setas verdes correspondem as projeções do tipo filopodia. Por último, as setas amarelas representam pontos agregados de fibras, característicos de invadopodia. (A) cultivo CC-20Econtrole. (B) cultivo CC-20Eslug. (C) cultivo CL28Econtrole. (D) cultivo CL-28Eslug. (A,B,C,D) aumento de 400x. 


\subsubsection{Tempo de duplicação celular}

A indução do processo de transição epitélio-mesenquimal pode interferir nas taxas de replicação das células que o sofrem. Portanto, nós avaliamos o tempo de duplicação das células com expressão exógena de SLUG, em comparação as células controle. O tempo de duplicação das células CC-20Eslug não diferiu de maneira notável nas células CC-20Econtrole, apresentando variação de aproximadamente 1,3 horas. Da mesma maneira, o tempo de duplicação das células CL-28Eslug e CL-28Econtrole foram próximos, com diferença, também, de 1,3 horas (Tabela 5).

Tabela 4 - Tempo de duplicação das células controle e das células com expressão exógena de SLUG.

\begin{tabular}{ccc}
\hline Cultivo Celular & Tempo de Duplicação (h) & Variação (h) \\
\hline CC-20Econtrole & 16,08 & $+1,32$ \\
CC-20Eslug & 17,4 & \\
CL-28Econtrole & 19,4 & $-1,3$ \\
CL-28Eslug & 18,09 & \\
\hline
\end{tabular}

Fonte: XAVIER, P.L.P. 2016

Legenda: as contagens foram realizadas em câmara de Neubauer, em intervalos regulares de 24 horas, em um total de 96 horas. 


\subsubsection{Avaliação da expressão gênica de fatores de transcrição associados a EMT e de genes alvos de SLUG}

Afim de descobrir se a expressão exógena de SLUG poderia alterar a expressão de outros fatores de transcrição associados a EMT e de genes com regiões promotoras alvo de SLUG, análises da expressão gênica de nove genes foram realizadas por PCR em tempo real. Primeiramente, a análise de expressão gênica dos fatores de transcrição STAT3, ZEB1 e ZEB2 foram realizadas. Após, a expressão de outros seis genes, conhecidos por serem alvos de SLUG ou estarem relacionados a EMT, foram realizados. São eles: CDH1 (E-caderina), CDH2 (N-Caderina), VDR (receptor de vitamina D), ABCB1 (gene de resistência a múltiplas drogas), BRCA2 (reparo de DNA) e HDAC1 (deacetilase de histonas). Em relação as células CC-20Econtrole e CC-20Eslug, os fatores de transcrição ZEB1 e ZEB2 não tiveram detectada expressão gênica, assim como já demonstrado em experimento anterior. A expressão do fator de transcrição STAT3 também não apresentou diferença significante entre CC-20Econtrole e CC-20Eslug (Gráfico 5). Os genes CDH2 e ABCB1 apresentaram ausência de expressão em ambas as células, enquanto a expressão dos genes CDH1 e HDAC1 não apresentou diferença significante. Por fim, nas células CC-20Eslug houve diminuição da expressão dos genes BRCA2 (P = 0.0277) e VDR $(\mathrm{P}=0.0009)$ (Gráfico 5).

Já em relação as células CL-28Econtrole e CL-28Eslug, não houve expressão dos fatores de transcrição STAT3 e ZEB1 em nenhuma das células. Curiosamente, a expressão do fator de transcrição ZEB2 foi reduzida nas células CL-28Eslug, em relação as células controle $(\mathrm{P}=0.0031)$. Não houve diferença significante em relação a expressão dos genes HDAC1, VDR, e ABCB1 entre as células. Por fim, nas células CL-28Eslug foram observados aumento da expressão dos genes BRCA2 (P = 0.0035), CDH1 ( $<$ 0.0001) e CDH2 (P = 0.0079) (Gráfico 6). 
Gráfico 5 - Avaliação da expressão gênica dos genes BRCA2, CDH1, HDAC1, STAT3 e VDR entre as células CC-20Econtrole e CC-20Eslug
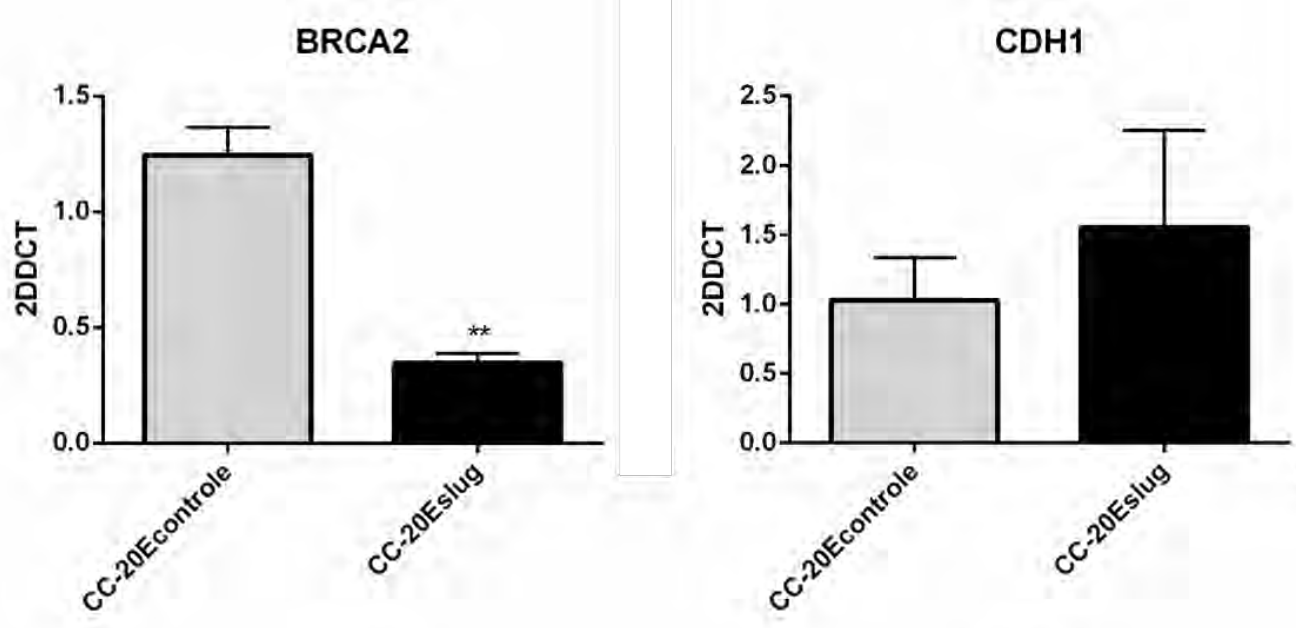

HDAC1

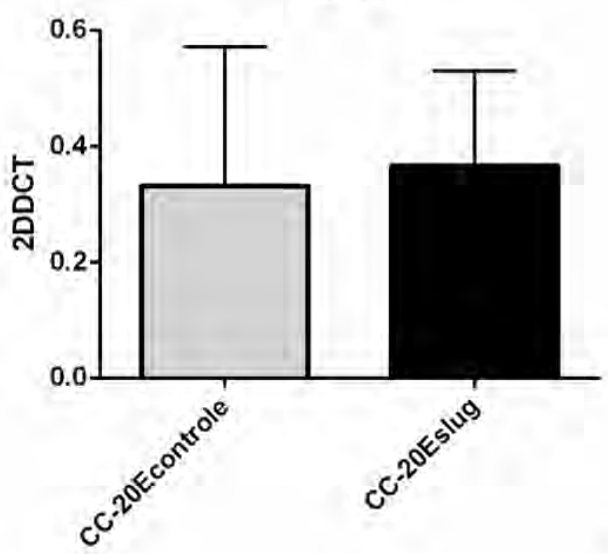

STAT3
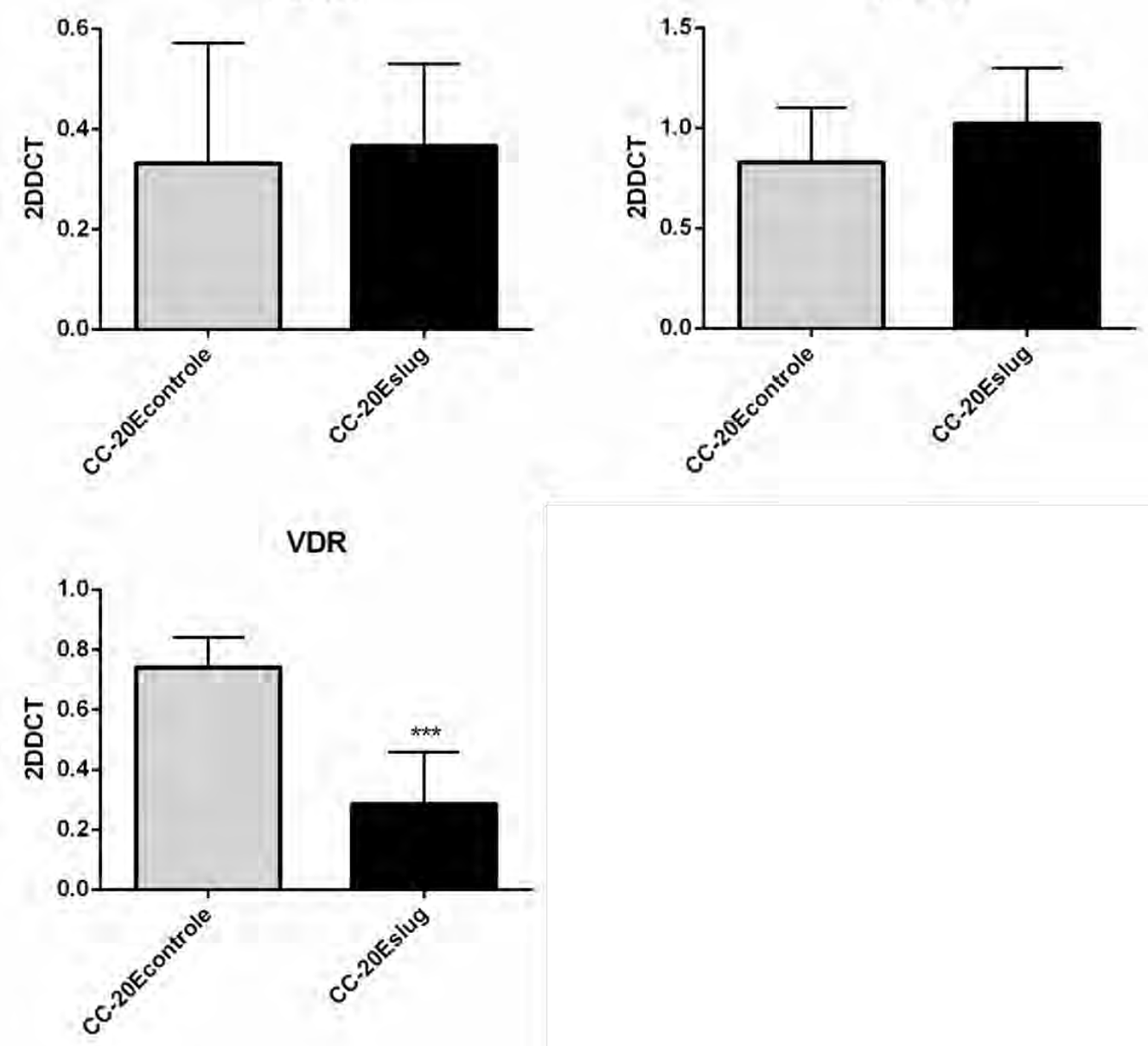

Fonte: XAVIER, P.L.P. 2016

Legenda: comparação da expressão gênica dos genes BRCA2, CDH1, HDAC1, STAT3 e VDR nas células CC-20Econtrole e CC-20E slug. Não houve detecção na expressão dos genes $\mathrm{CDH} 2$, ZEB1 e ZEB2 em ambos os cultivos, não havendo assim, representação gráfica. Teste T paramétrico de Student $(* * \mathrm{p}=0,0010 ; * * * \mathrm{p}=0,0009)$. 
Gráfico 6 - Avaliação da expressão gênica dos genes BRCA2, CDH1, CDH2, HDAC1, VDR e ZEB2 entre as células CL-28Econtrole e CL-28Eslug
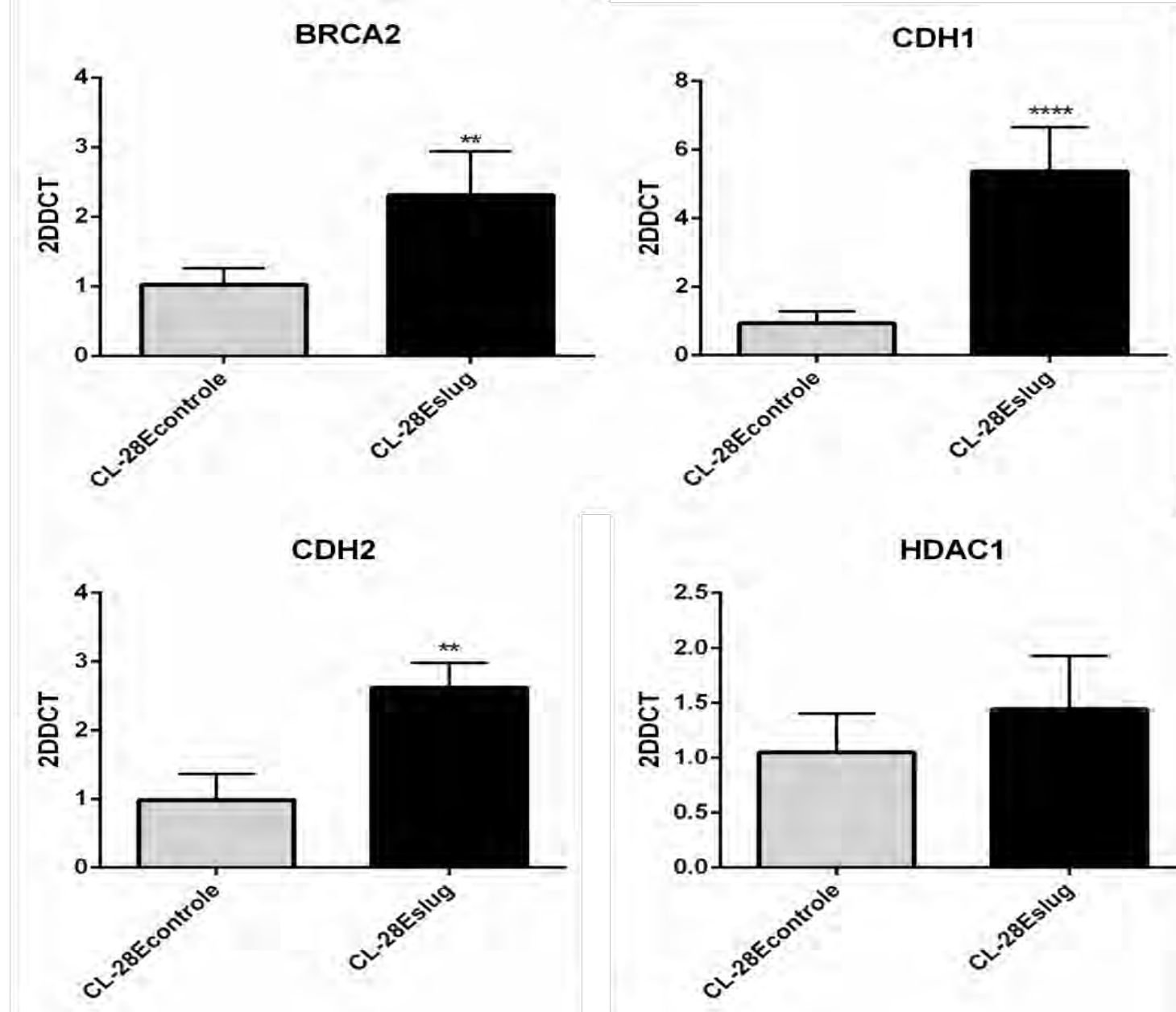

HDAC1
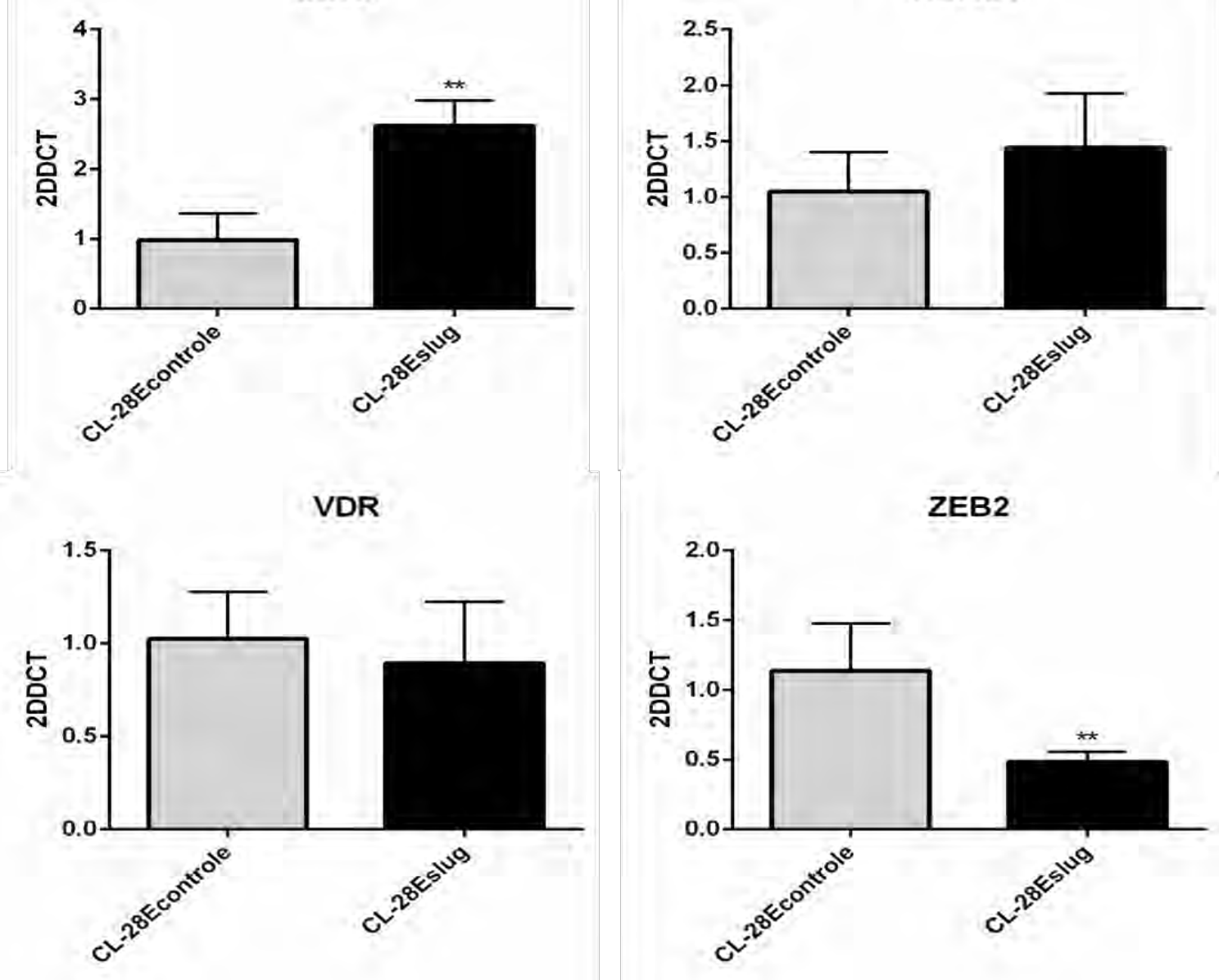

Fonte: XAVIER, P.L.P. 2016

Legenda: comparação da expressão gênica dos genes BRCA2, CDH1, CDH2, HDAC1, VDR e ZEB2 nas células CC-20Econtrole e CC-20E slug. Não houve detecção na expressão dos genes STAT3 e ZEB1 em ambos os cultivos, não havendo assim, representação gráfica. Teste T não paramétrico de Mann-Whitney $(* * \mathrm{p}=0,0079)$. Teste T paramétrico de Student $(* * \mathrm{p}=$ $0,0012$ e 0,$0028 ; * * * * p<0,0001)$. 


\subsubsection{Avaliação da sensibilidade aos fármacos doxorrubicina e paclitaxel}

Para investigar se a superexpressão de SLUG poderia influenciar a sensibilidade a fármacos quimioterápicos, as células epiteliais controle e as com expressão forçada de SLUG foram submetidas a testes de citotoxidade para os quimioterápicos doxorrubicina e paclitaxel. A sensibilidade das células aos quimioterápicos foi então analisada a partir da concentração de inibição de $50 \%$ da viabilidade das células ( $\mathrm{IC}_{50}$ ), obtida durante os experimentos. Quanto a sensibilidade a doxorrubicina, foi observado efeito dosedependente, entretanto, nenhuma diferença significante foi observada entre as células CC20Econtrole e CC-20Eslug, assim como entre CL-28Econtrole e CL-28Eslug (Tabela 6; gráfico 7). Em contrapartida, além do efeito dose-dependente, foi observado que as células com expressão exógena de SLUG apresentaram maior resistência ao quimioterápico paclitaxel, tanto entre as células CC-20Econtrole e CC-20Eslug (P < 0.0001), quanto entre as células CL-28Econtrole e CL-28Eslug $(\mathrm{P}=0.0152)$ (Tabela 6; gráfico 7).

Tabela 5 - Valores de $\mathrm{IC}_{50}$ após tratamento das células controle e com expressão exógena de SLUG com doxorrubicina e paclitaxel

\begin{tabular}{ccc}
\hline Cultivo Celular & Doxorrubicina - ng/ml & Paclitaxel - nM/ml \\
\hline CC-20Econtrole & $80,6 \pm 35,02$ & $0,51 \pm 0,17$ \\
CC-20Eslug & $91,04 \pm 15,03$ & ${ }^{* * * *}$ \\
& & $1,36 \pm 0,21$ \\
CL-28Econtrole & $62,98 \pm 1,01$ & $0,04 \pm 0,04$ \\
& & $*$ \\
CL-28Eslug & $68,54 \pm 12,28$ & $0,15 \pm 0,06$ \\
\hline
\end{tabular}

Fonte: XAVIER, P.L.P. 2016

Legenda: valores de $\mathrm{IC}_{50}$ dos fármacos doxorrubicina e paclitaxel nas células controle e com expressão exógena de SLUG. Não houve diferença em relação ao fármaco doxorrubicina em ambas as células. Entretanto, as células com superexpressão de SLUG foram mais resistentes a paclitaxel em ambos os cultivos. Teste T paramétrico de Student $(* * * * \mathrm{p}<0,0001)$. Teste T não paramétrico de Mann-Whitney ( $* \mathrm{p}=0,0152)$. 
Gráfico 7 - Avaliação da citotoxidade dos fármacos doxorrubicina e paclitaxel nas células controle e com expressão exógena de SLUG
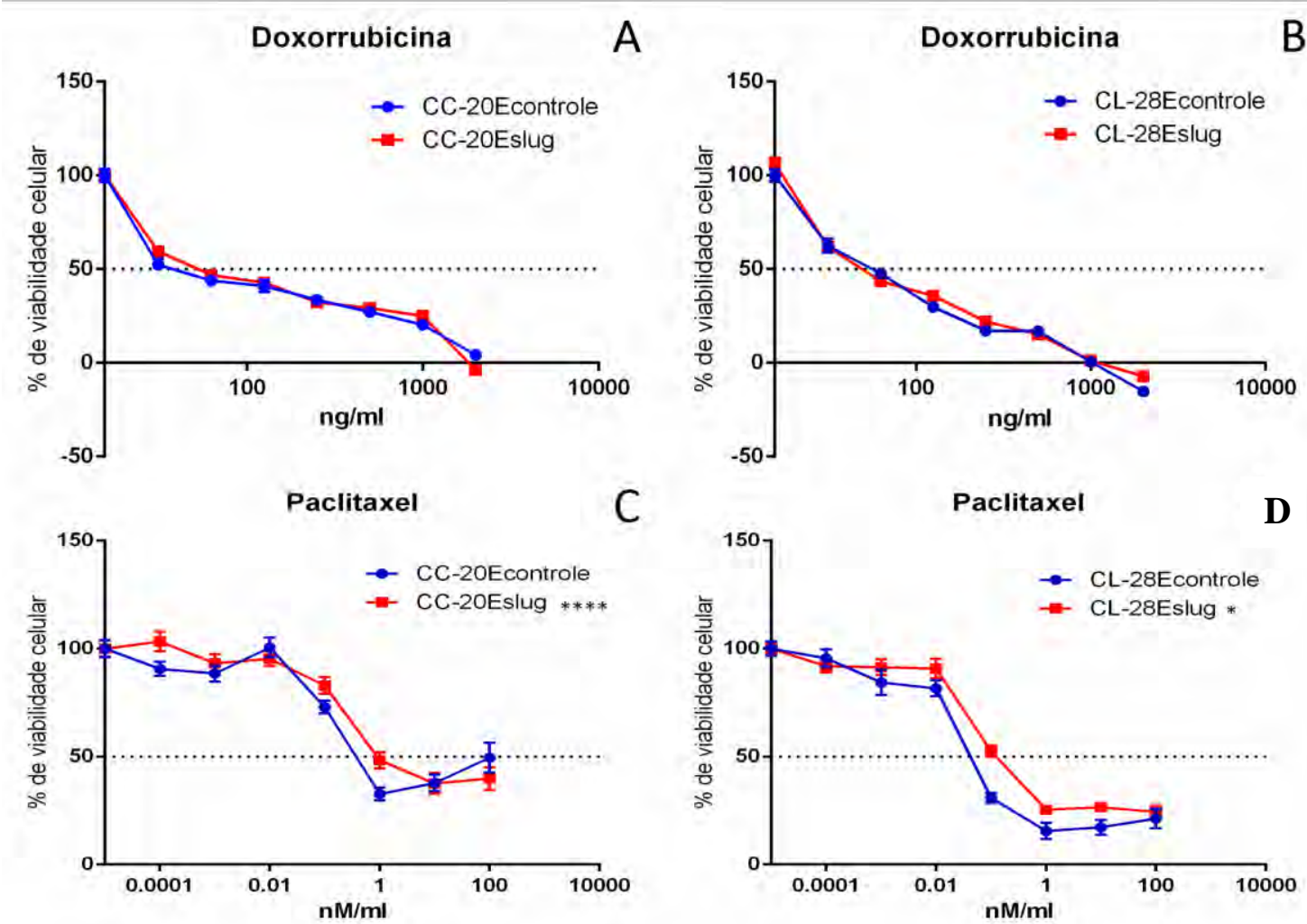

Fonte: XAVIER, P.L.P. 2016

Legenda: análise do efeito citotóxico e dose-dependente dos fármacos doxorrubicina e paclitaxel nas células controle e com expressão exógena de SLUG. Cada ponto da curva de regressão não-linear corresponde a uma concentração diferente dos fármacos, sendo o ponto inicial o controle e os demais seguindo diluição seriada de (1:2) para doxorrubicina e (1:10) para paclitaxel. Concentração inicial de doxorrubicina $=2.000 \mathrm{ng} / \mathrm{ml}$. Concentração inicial de paclitaxel $=4.000 \mathrm{nM} / \mathrm{ml}$. Teste $\mathrm{T}$ paramétrico de Student $(* * * * \mathrm{p}<0,0001)$. Teste $\mathrm{T}$ não paramétrico de Mann-Whitney (*p = 0,0152).

\subsubsection{Avaliação do potencial de invasão das células controle e com superexpressão de SLUG}

Considerando que a maior expressão de fatores de transcrição como SLUG podem estar associados com o potencial de invasão das células cancerosas, foi avaliado a capacidade de invasão das células controle e SLUG em insertos transwell preenchidos 
com gel ECM, mimetizador da matriz extracelular. As células CC-20Eslug apresentaram maior capacidade de degradação do gel ECM e invasão do inserto, em relação as células controle ( $\mathrm{P}=0.0070)$ (Figura 22; gráfico 8). Curiosamente, as células CL-28Eslug apresentaram resultado inverso ao observado nas células CC-20Eslug, apresentando diminuição do seu potencial de invasão, em relação as células CL-28Econtrole ( $\mathrm{P}=$ 0,0016) (Figura 22; gráfico 8).

Figura 22 - Capacidade de invasão dos cultivos controle e com expressão exógena de SLUG em insertos transwell

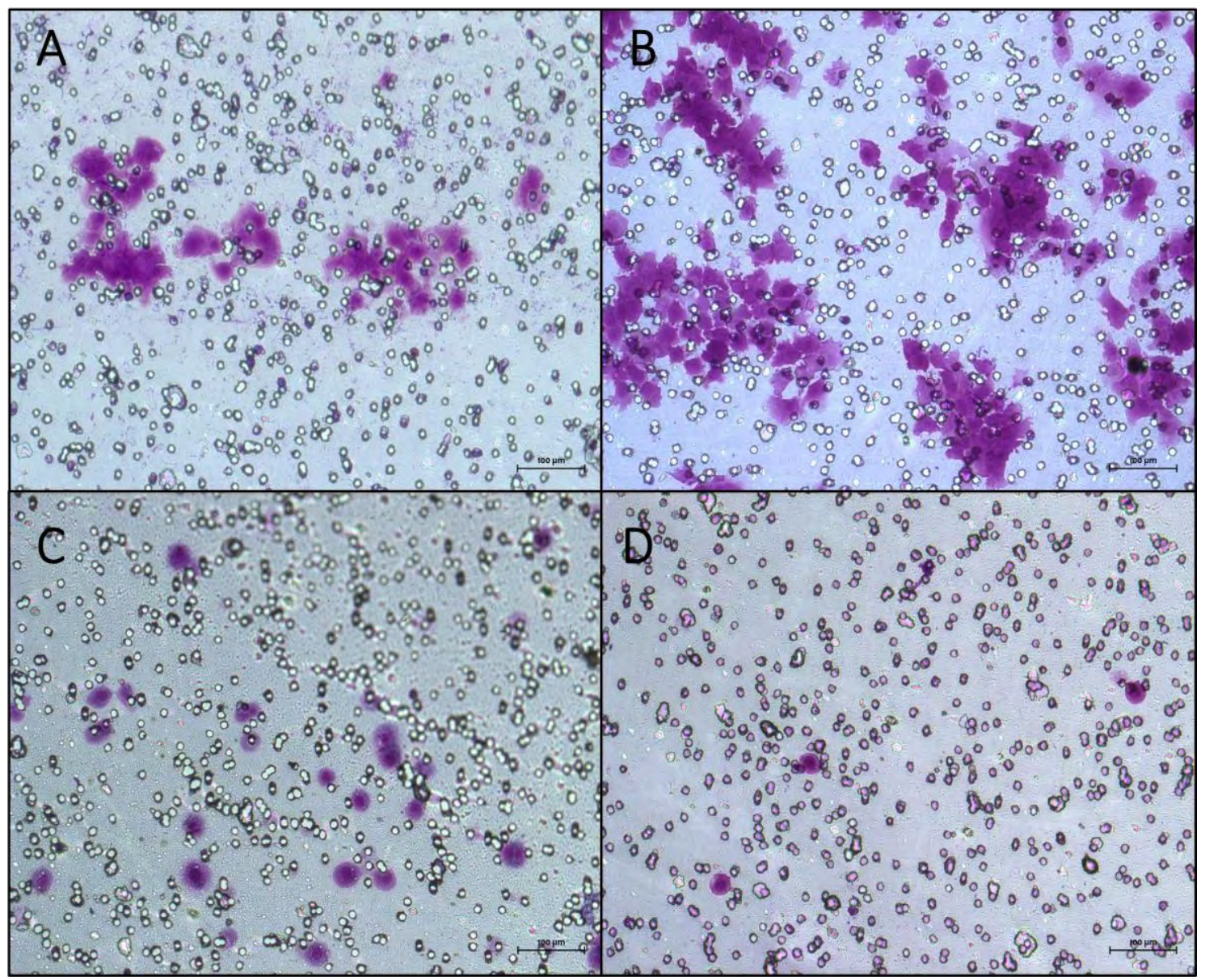

Fonte: XAVIER, P.L.P. 2016

Legenda: as células CC-20Eslug (B) apresentaram maior potencial de invasão do que as células CC-20Econtrole (A). Entretanto, as células CL-28Eslug (D) apresentaram diminuição de seu potencial de invasão em relação as células CL-28Econtrole (C). (A,B,C,D) imagens capturadas em aumento de 100x. 
Gráfico 8 - Capacidade de invasão dos cultivos controle e com expressão exógena de SLUG em insertos transwell
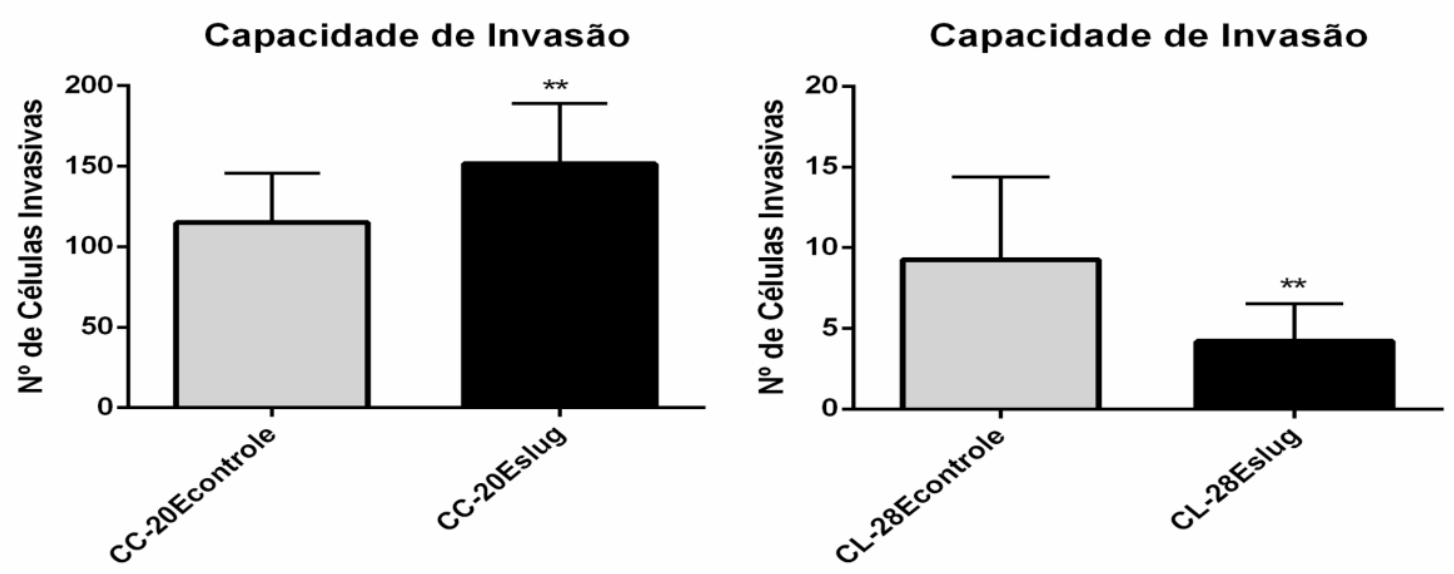

Fonte: XAVIER, P.L.P. 2016

Legenda: as células CC-20Eslug apresentaram maior potencial de invasão do que as células CC-20Econtrole. Entretanto, as células CL-28Eslug apresentaram diminuição de seu potencial de invasão em relação as células CL-28Econtrole. Teste T paramétrico de Student $(* * p=$ $0,0070 ; * * \mathrm{p}=0,0016)$.

\subsubsection{Comparação do potencial tumorigênico entre as células controle e com expressão expressão exógena de SLUG}

A formação de tumoresferas em cultivos de baixa aderência é uma característica típica de células com alto potencial tumorigênico e de células iniciadoras de tumores. Afim de avaliar se a expressão exógena de SLUG poderia interferir na formação de tumoresferas, células controle e com expressão exógena de SLUG foram plaqueadas, e a quantidade e o tamanho das tumoresferas foram avaliados nos dias 7, 14 e 21 de cultivo. Quanto as células CC-20Econtrole e CC-20Eslug, só houve diferença significante na primeira contagem (dia 7) $(\mathrm{P}=0.0279)$, quando as células com superexpressão para SLUG apresentaram maior quantidade de formação de tumoresferas por poço. Em relação aos tamanhos das tumoresferas, só foi observada diferença significante no dia 21 de cultivo, quando as esferas CC-20Eslug apresentaram-se maiores $(P=0.0038)$. Já em relação as células CL-28Econtrole e CL-28Eslug, houve diferença significante na 
formação de tumoresferas em todas as contagens (dias 7, 14 e 21), sendo que as tumoresferas com expressão exógena de SLUG apresentaram-se em maior quantidade (P $<0.0001 ; \mathrm{P}<0.0001 ; \mathrm{P}=0.0010)$. Por fim, as tumoresferas com expressão exógena de SLUG apresentaram-se maiores nos dias $7(\mathrm{P}<0.0001)$ e $21(\mathrm{P}<0.0001)$ do experimento. No decorrer do experimento, pode-se observar que houve uma diminuição do número de tumoresferas em todos os cultivos. Entretanto, em relação as células CL-28Econtrole e CL-28Eslug, as células com expressão exógena de SLUG, mantiveram um maior número de tumoresferas em todas as contagens. Ao mesmo tempo, as tumoresferas CL-28Eslug que sobreviveram no decorrer dos vinte e um dias, apresentaram seu tamanho quase duas vezes maior do que no início do experimento.

Gráfico 9 - Comparação do número e tamanho das tumoresferas formadas nos cultivos controle e com expressão exógena de SLUG
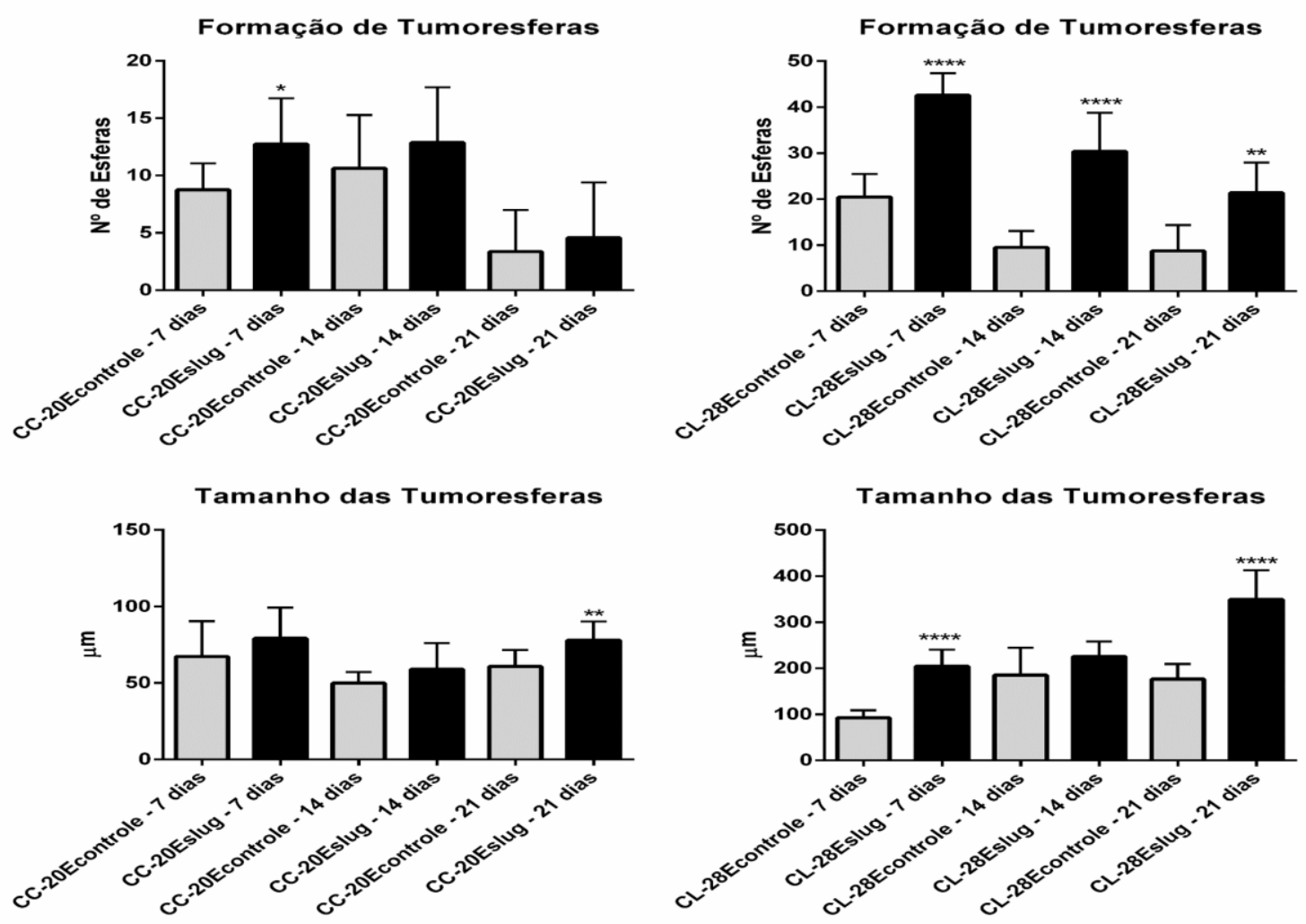

Fonte: XAVIER, P.L.P. 2016

Legenda: formação de tumoresferas em placas de baixa aderência entre os cultivos controle e com expressão exógena de SLUG. Os resultados mostraram que o cultivo CC-20Eslug apresentou maior formação de esferas apenas no sétimo dia de contagem, em relação as células CC-20Econtrole. Entretanto, só houve diferença de tamanho das tumoresferas, após vinte e um dias. Já em relação as células CL-28Econtrole e Cl-28Eslug, as células com expressão exógena de SLUG apresentaram maior formação de esferas em todos os dias de contagem, além de se apresentarem maiores nos dias sete e vinte e um de experimento. 
Figura 23 - Células controle e com expressão exógena de SLUG após um dia de cultivo em placas de baixa aderência

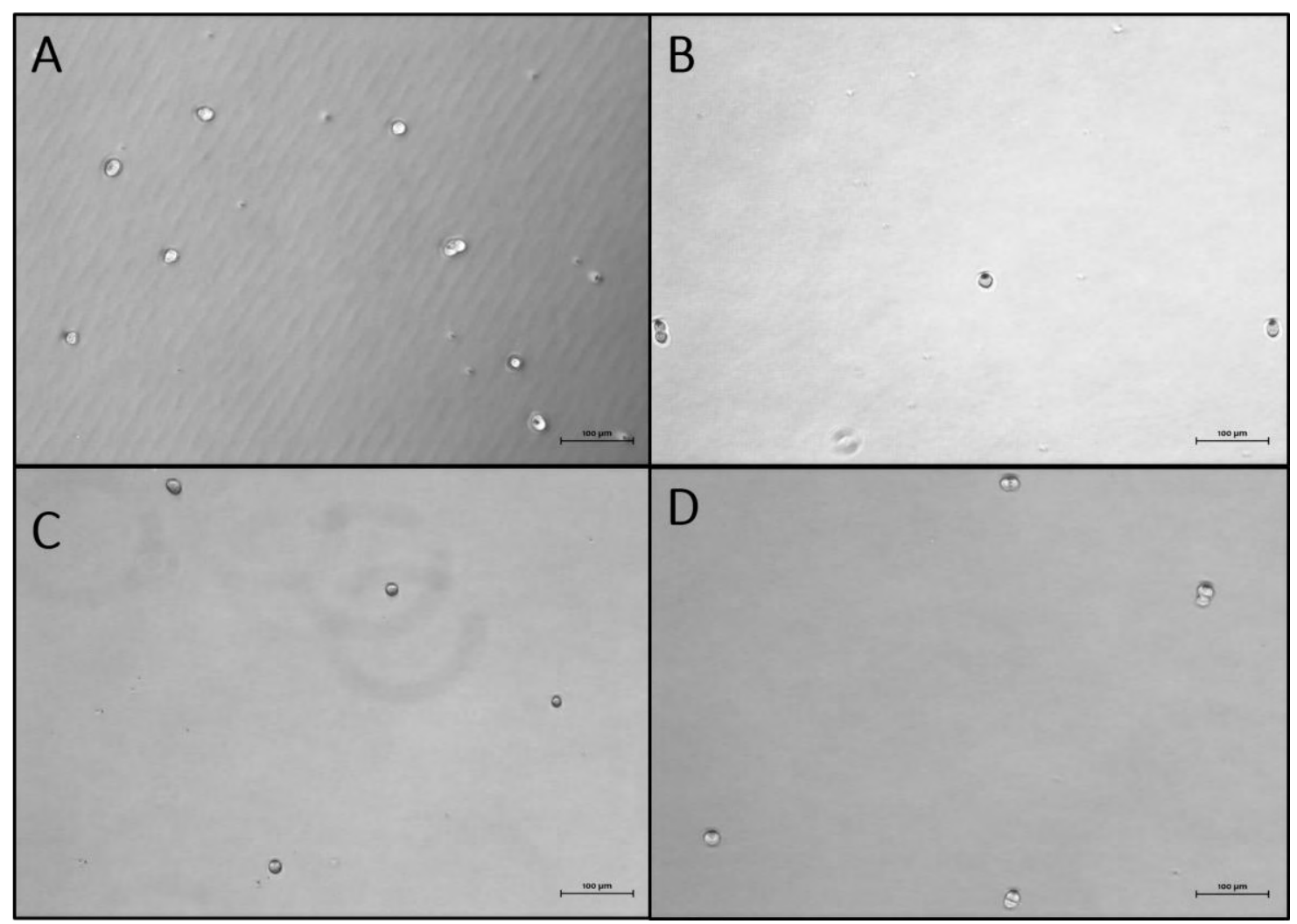

Fonte: XAVIER, P.L.P. 2016

Legenda: após um dia de cultivo em placas de baixa aderência as células ainda se mantinham individualizadas. (A) CC-20Econtrole. (B) CC-20Eslug. (C) CL-28Econtrole. (D) CL-28Eslug. $(\mathrm{A}, \mathrm{B}, \mathrm{C}, \mathrm{D})$ aumento de $100 \mathrm{x}$. 
Figura 24 - Formação de tumoresferas após sete dias de cultivo em placas de baixa aderência

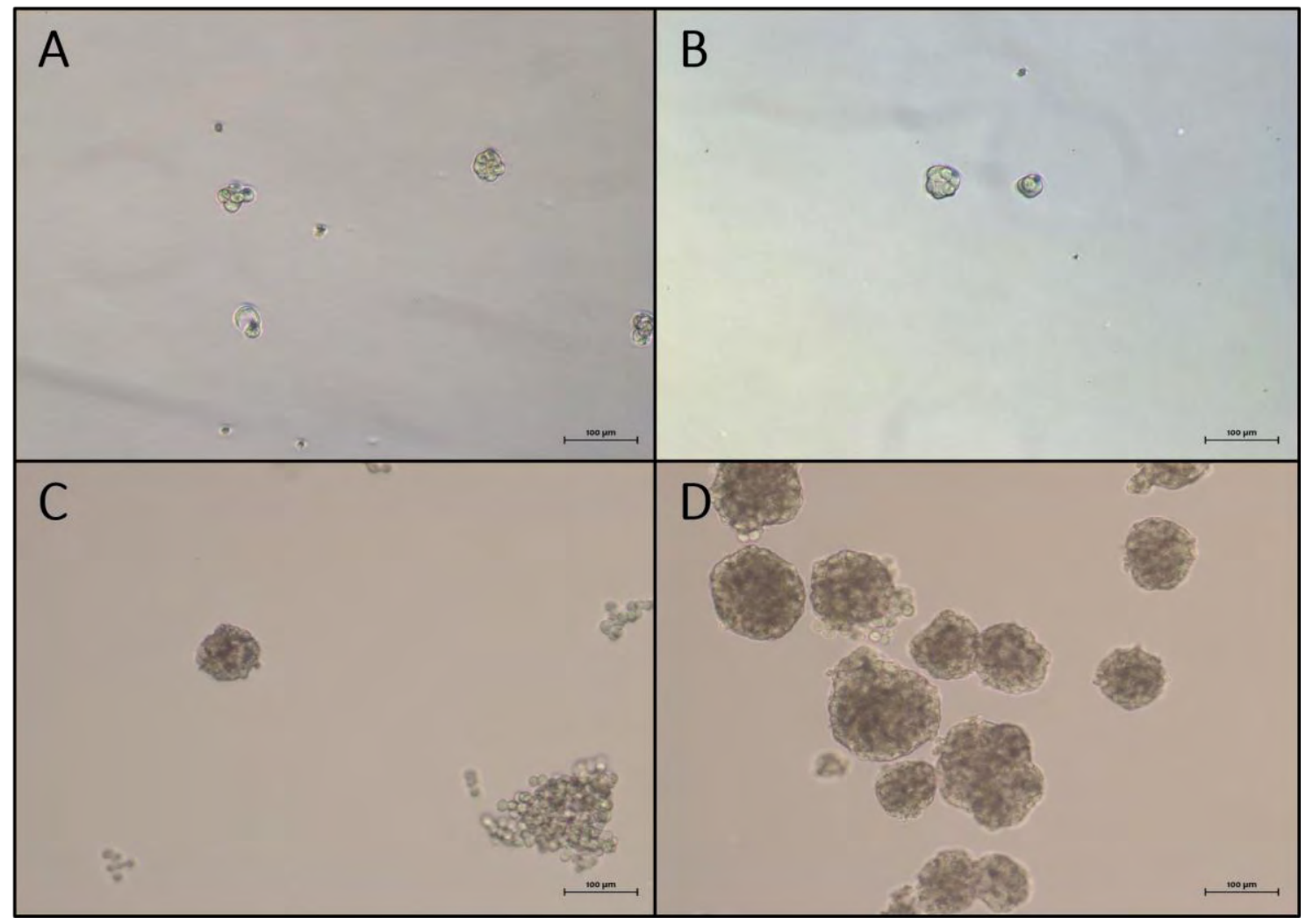

Fonte: XAVIER, P.L.P. 2016

Legenda: formação de tumoresferas em placas de baixa aderência após sete dias de cultivo. Células CC-20Eslug (B) apresentaram maior formação de tumoresferas do que as células CC20Econtrole (A). Entretanto, nenhuma diferença foi observada quanto ao tamanho das esferas. Já em relação as células CL-28Econtrole (C) e CL-28Eslug (D), as células com expressão exógena de SLUG formaram um número maior de tumoresferas, além destas apresentarem tamanho maior nessas células, em relação as células controle. Além disso, pode-se observar, além da formação de esferas, formação de aglomerados de células no cultivo CL-28Econtrole, estruturas que não foram observadas nas células com expressão exógena de SLUG. Esses aglomerados não foram inseridos na contagem de esferas. (A,B,C,D) aumento de 10x. 
Figura 25 - Formação de tumoresferas após quatorze dias de cultivo em placas de baixa aderência

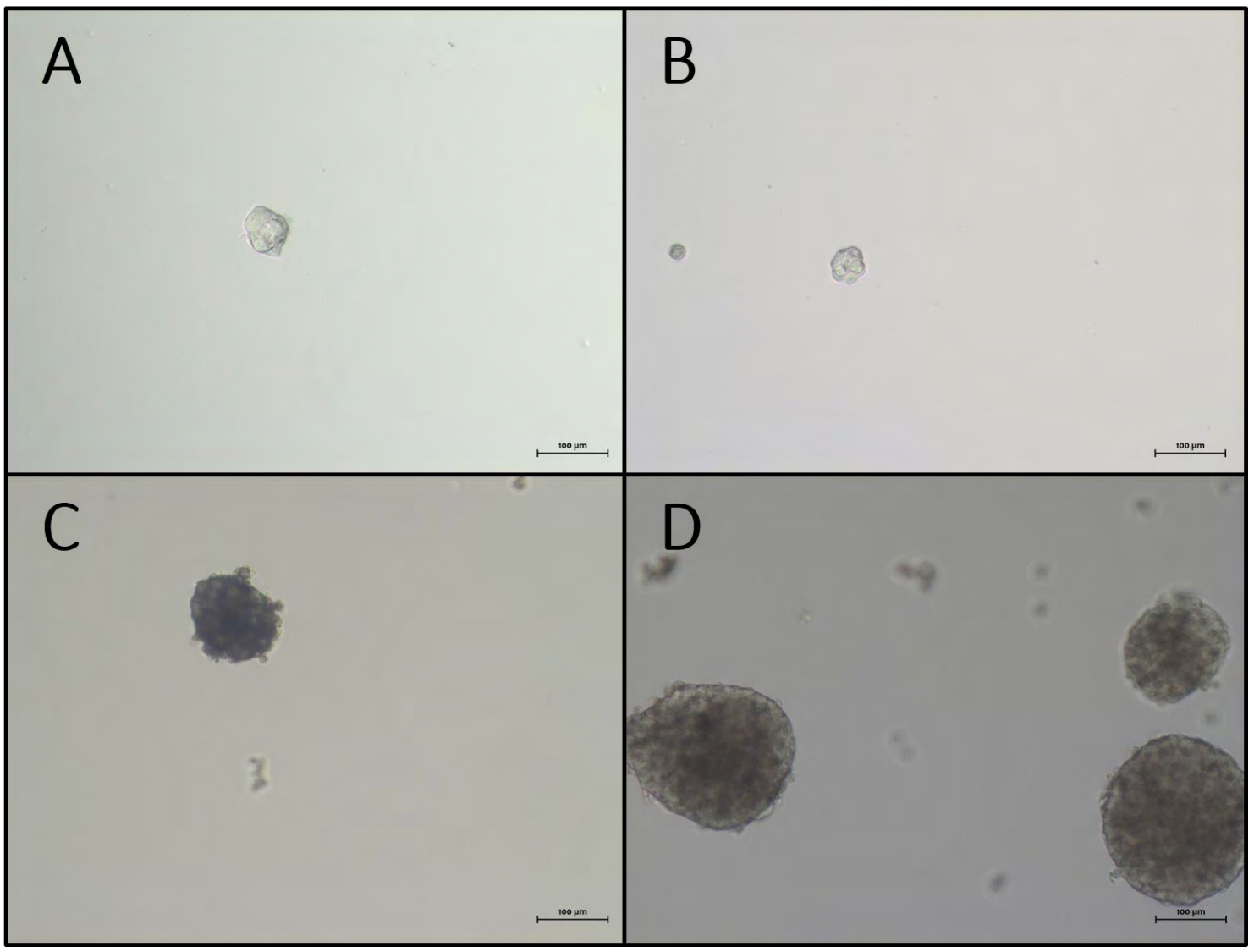

Fonte: XAVIER, P.L.P. 2016

Legenda: formação de tumoresferas em placas de baixa aderência após quatorze dias de cultivo. Em relação as células CC-20Econtrole (A) e CC-20Eslug (B) não houve diferença significante entre o número de formação de tumoresferas e o tamanho destas. Já em relação as células CL28Econtrole (C) e CL-28Eslug (D), as células com expressão exógena de SLUG formaram um número maior de tumoresferas, porém após quatorze dias, não apresentaram diferença nos tamanhos destas. (A, B, C, D) aumento de 10x. 
Figura 26 - Formação de tumoresferas após vinte e um dias em cultivo de baixa aderêcia

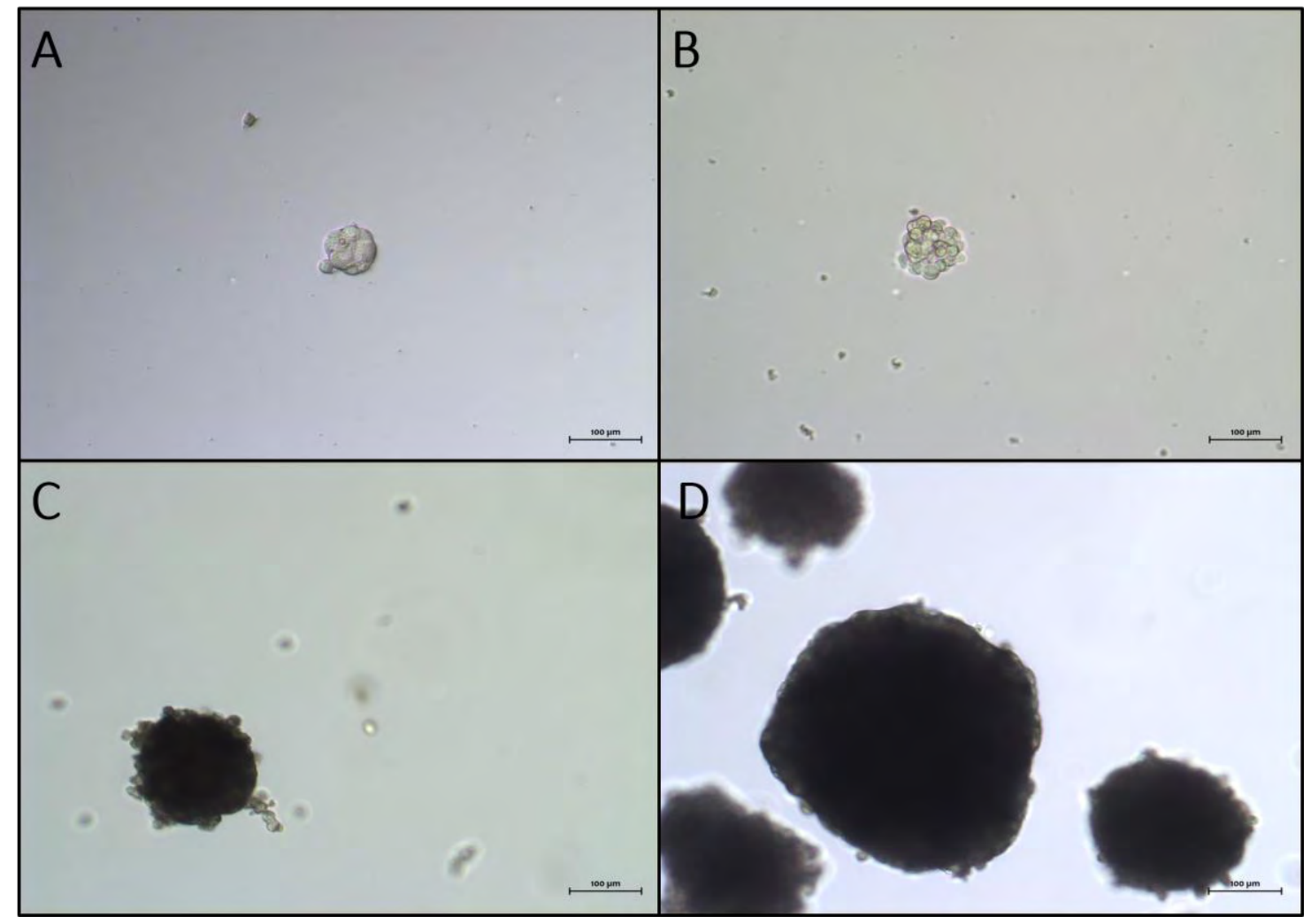

Fonte: XAVIER, P.L.P. 2016

Legenda: formação de tumoresferas em placas de baixa aderência após vinte e um dias de cultivo. Em relação as células CC-20Econtrole (A) e CC-20Eslug (B) não houve diferença significante entre o número de formação de tumoresferas, porém as tumoresferas do cultivo CC-20Eslug se apresentaram maiores. Já em relação as células CL-28Econtrole (C) e CL28Eslug (D), as células com expressão exógena de SLUG formaram um número maior de tumoresferas, além de apresentaram tamanhos maiores em relação as células controle. (A, B, C, D) aumento de 10x. 


\section{DISCUSSÃO}

\subsection{SOBRE A VARIAÇÃO NA EXPRESSÃO DE FATORES DE TRANSCRIÇÃO ASSOCIADOS A EMT EM CÉLULAS ORIUNDAS DE CARCINOMAS MAMÁRIOS CANINOS E SUA CORRELAÇÃO COM O POTENCIAL DE INVASÃO}

Um dos principais entraves, não só em relação aos tratamentos de neoplasias mamárias, mas possivelmente para todos os outros tipos de câncer, se baseia na heterogeneidade tanto intertumoral, quanto intratumoral. A heterogeneidade de células em um tumor surge durante o desenvolvimento neoplásico e pode ser consequência de uma combinação entre a instabilidade genômica das células e processos epigenéticos (MCGRANAHAN; SWANTON, 2015), além da seleção exercida pelo microambiente tecidual, gerando diferentes populações que podem ser distintas em uma série de fatores como morfologia, proliferação, resistência à terapias, potencial tumorigênico e, inclusive, hierarquia, no que se diz respeito ao desenvolvimento do tumor (BROOKS; BURNESS; WICHA, 2015). Um dos processos que pode induzir a heterogeneidade intratumoral das células, é conhecido como transição epitélio-mesenquimal, no qual algumas células com fenótipo epitelial, podem adquirir características típicas de células mesenquimais (NEELAKANTAN; DRASIN; FORD, 2015).

Um estudo realizado anteriormente por nosso grupo caracterizou quatro cultivos de células oriundos de carcinomas mamários caninos, quanto sua morfologia, tempo de duplicação, expressão dos filamentos intermediários citoqueratina, vimentina e alfaactina, além de cariótipo (CORDEIRO, 2015). Ao final da caracterização, os resultados demonstraram que dois cultivos apresentavam fenótipo epitelial, enquanto os outros dois cultivos apresentavam células com fenótipo mesenquimal, corroborando com resultados de que carcinomas podem apresentar simultaneamente células com fenótipos epiteliais e mesenquimais (WENDT et al., 2014). No presente estudo, hipotetizou-se então que haveriam diferenças na expressão de alguns genes associados a transição epitéliomesenquimal entre os cultivos padronizados. Como esperado, houve grande variação na expressão dos FT SLUG, STAT3, ZEB1 e ZEB2 entre os cultivos, sendo que a expressão de SLUG, STAT3 e ZEB1 foram significativamente maiores nas células com fenótipo mesenquimal, demonstrando associação entre a expressão desses fatores de transcrição e a indução ou manutenção do fenótipo mesenquimal das células em neoplasias mamárias, principalmente em humanos (CHAFFER et al., 2013; CHIMGE et al., 2011; CHUNG et al., 2014; HUGO et al., 2013; PHILLIPS; KUPERWASSER, 2014). O fator de 
transcrição ZEB2 foi a única exceção observada, sendo mais expresso nas células do cultivo CL-28E, consideradas epiteliais. Esse resultado, é corroborado pelo estudo realizado em amostras parafinadas de carcinoma micropapilar invasivo caninas, que demonstraram, por imunohistoquímica, maior marcação nuclear de ZEB2 em células neoplásicas epiteliais, localizadas principalmente nas regiões 'in situ' dos tumores (GAMBA et al., 2014).

Transição epitélio mesenquimal e a maior expressão de genes associados a esse processo estão intimamente relacionados com a maior capacidade de invasão das células cancerosas e, consequentemente, com os processos metastáticos (BRABLETZ, 2012). Sendo assim, nós avaliamos a capacidade de invasão dos quatro cultivos padronizados. Ao contrário do que é observado na literatura (LAMBERTINI et al., 2012; MCFADDEN; HEITZMAN-POWELL, 2015; SARRIÓ et al., 2008), as células com fenótipo mesenquimal e com maior expressão de genes associados a EMT apresentaram menor capacidade de invasão do que as células de um dos cultivos epiteliais cultivo CC-20E, caracterizado como epitelial e com baixos níveis de expressão dos genes associados a EMT. Alguns estudos, entretanto, demonstraram que a maior expressão de STAT3, encontrado em nossas células mesenquimais, pode contribuir para o aumento da expressão do inibidor tecidual de metaloproteinases do tipo 1 (TIMP1), impedindo a expressão dessas enzimas degradadoras de matrix extracelular, diminuindo assim, a capacidade de invasão das células (DIEN et al., 2006; LAI et al., 2004), mesmo em modelos in vitro. Ainda assim, outros estudos tem demonstrado a importância de STAT3 na ativação de metaloproteinases do tipo 2 e consequente capacidade de invasão das células cancerosas (XIE et al., 2004). Assim, também caracterizamos o citoesqueleto de actina destas células. Como pode ser observado, as células CC-20E, caracterizadas como epiteliais, apresentaram muitos pontos de aglomerados de fibras, conhecidos como invadopodia, em comparação as células mesenquimais. Essas protrusões ricas em actina estão amplamente associadas com degradação da matrix extracelular e, consequentemente, com o potencial de invasão e metástase das células cancerosas (JACOB; PREKERIS, 2015; PAZ; PATHAK; YANG, 2014). Esse fator pode ser muito relevante em relação ao maior potencial de invasão das células CC-20E, em comparação as células mesenquimais. 


\subsection{SOBRE OS EFEITOS DA EXPRESSÃO EXÓGENA DE SLUG EM CÉLULAS DE CARCINOMAS MAMÁRIOS CANINOS}

Recentemente, muito tem-se abordado sobre uma população de células conhecidas como células iniciadoras de tumores (CITs). De acordo com a teoria de desenvolvimento hierárquico das neoplasias, essa população estaria no topo da hierarquia, devido ao seu potencial tumorigênico, sua capacidade de auto-renovação e de resistência à fármacos antineoplásicos, sendo fundamental para o desenvolvimento e manutenção do tumor, além das possíveis recidivas tumorais (PATTABIRAMAN; WEINBERG, 2014). Uma série de estudos, tem demonstrado que o fenótipo de CIT está associado ao processo de transição epitélio-mesenquimal (EMT), que assegura uma série de alterações nas células que o sofrem, tornando-as mais malignas (BRABLETZ, 2012). Esse processo, pode ser ativado pela expressão de uma série de fatores de transcrição como SNAI1, SLUG, ZEB1, ZEB2 e TWIST (ANSIEAU; COLLIN; HILL, 2014).

No presente estudo, demonstrou-se que a expressão exógena de SLUG pode induzir células epiteliais, oriundas de carcinomas mamários caninos, a um fenótipo mais maligno e que mimetiza as características apresentadas pelas CITs. Através do ensaio de formação de esferas em placas de baixa aderência, amplamente utilizado para caracterização de CITs através da avaliação do potencial tumorigênico e de autorenovação (BECK; BLANPAIN, 2013), percebeu-se que a expressão exógena de SLUG promoveu o aumento da formação e o tamanho das esferas nos cultivos CC-20E e CL28E. Durante os vinte e um dias de experimento, os resultados demonstraram que houve uma diminuição no número de esferas, provavelmente devido a morte ou ao processo de diferenciação das mesmas. Entretanto, pelo menos em um dos cultivos, (CL-28E) as tumoresferas com expressão exógena de SLUG, mantiveram-se em maior número e apresentaram quase o dobro do tamanho das esferas iniciais, sugerindo que SLUG é relevante para a manutenção das esferas em cultivo in vitro a longo prazo. Resultados semelhantes foram demonstrados por Guo e colaboradores, nos quais pode-se observar que a capacidade de formação e a manutenção das tumoresferas in vitro, é dependente do fator de transcrição SLUG associado ao fator de transcrição SOX9 (GUO et al., 2012). A expressão de SLUG, associada a expressão do fator de necrose tumoral, também foi associado ao fenótipo de CITs, gerando uma população de células CD44 $/ \mathrm{CD} 24^{+}$com maior formação de esferas (BHAT-NAKSHATRI et al., 2010). 
As células CC-20Eslug e CL-28Eslug também apresentarem-se mais resistentes ao quimioterápico paclitaxel. Esse fármaco age em células que se replicam rapidamente e tem como princípio, a ligação as proteínas tubulinas dos microtúbulos, impedindo que eles se despolimerizem e realizem a mitose, levando a célula a morte (KHANNA; ROSENBERG; VAIL, 2015). Aqui, demonstrou-se que SLUG não interferiu nas taxas de proliferação das células e portanto, a maior resistência das células SLUG deveria estar relacionada a algum fator no mecanismo utilizado por paclitaxel. Um estudo realizado por Tamura e colaboradores, demonstrou que a expressão exógena de SLUG aumentou a resistência a vários quimioterápicos que continham agentes ligantes a tubulinas, como vincristina, paclitaxel e vinorelbina, mas não para outros quimioterápicos que possuíam mecanismos diferentes de ação. Seus resultados também demonstraram que SLUG inibia a expressão das tubulinas $\beta$ III e $\beta$ IVa, consideradas essenciais para a ação dos fármacos associados a tubulinas. Essa inibição é realizada em nível transcricional, ligando-se diretamente as regiões promotoras dos genes que as transcrevem (TAMURA et al., 2013). Além desse, outro estudo demonstrou que o silenciamento de SLUG, aumentava a sensibilidade das células a paclitaxel (CHEN et al., 2013).

Os mecanismos pelos quais SLUG pode induzir a geração de células mais malignas e com fenótipo característicos de CIT, remetem, geralmente, a indução do processo completo de EMT (BHAT-NAKSHATRI et al., 2010; BOLÓS et al., 2003; GUO et al., 2012). Entretanto, algumas evidências sugerem que a expressão de SLUG está, principalmente, associada a uma outra vertente do processo de transição epitéliomesenquimal, conhecida como parcial ou híbrida (JOLLY, 2015; LEROY et al., 2007 SAVAGNER et al., 2005; WELCH-REARDON et al., 2014). Assim como nesses estudos, nossos resultados também sugerem que a maior malignidade e o fenótipo de CIT adquiridos pelas células neoplásicas caninas, tenham sido consequência do processo de EMT parcial, induzido pela expressão exógena de SLUG. As células epiteliais não se reestruturaram morfologicamente para mesenquimais, o que seria característico de um EMT completo. Ao invés, mantiveram seu formato poligonal, apresentando pouco espaço intracelular e formação de vários grupos de células. A única modificação visível ao microscópio óptico, foi observada no cultivo CL-28Eslug, que se distribuiu de maneira diferente em relação as células controle. Pode-se notar, a origem de grupos mimetizando túbulos semidiferenciados, os quais eram compostos por uma cadeia bem delimitada de células nas suas extremidades. Esse processo de formação de túbulos é conhecido como 
tubulogênese, e a expressão de SLUG parece ser fundamental para sua manutenção em neoplasias mamárias humanas, principalmente em carcinomas ductal invasivo (CÔME et al., 2006). Além disso, outro estudo demonstrou a importância de SLUG na formação de túbulos, induzidos por transição epitélio-mesenquimal parcial, em células MDCK (Madin-Darby canine kidney), oriundas de rim canino (LEROY; MOSTOV, 2007).

Os resultados observados referentes a expressão de citoqueratina e vimentina e nas análises de expressão gênica também sugerem a indução do processo de EMT parcial através da expressão exógena de SLUG. As células CC-20Eslug, mantiveram a expressão de citoqueratina, já observada nas células CC-20Econtrole, e ao mesmo tempo, aumentaram a expressão dos filamentos intermediários vimentina. Já nas células CL28Eslug, observou-se a diminuição da expressão dos filamentos de citoqueratina, em relação as células controle, e a manutenção da expressão dos filamentos de vimentina. Ao mesmo tempo, pode-se observar que houve um aumento na expressão do gene codificante de E-caderina, concomitante a expressão do gene codificante de $\mathrm{N}$-caderina. Esses resultados em conjunto, demonstram que houve um equilíbrio entre a expressão de marcadores epiteliais, como a citoqueratina e a E-caderina, e de marcadores mesenquimais, como a vimentina e a $\mathrm{N}$-caderina reforçando a importância de ambos os marcadores durante o processo de EMT parcial (JOLLY, 2015).

Apesar de SLUG, ZEB1 e ZEB2 apresentarem-se co-expressos em alguns estudos e estarem fortemente associados a transição epitélio-mesenquimal e ao fenótipo de CIT (GUAITA et al., 2002; LEHMANN et al., 2016; QI et al., 2012; SHIMODA et al., 2012), nossos resultados não demonstraram a mesma relação. Corroborando com nossos dados, Ye e colaboradores demonstraram em células MDA-MB-231, oriundas de câncer de mama humano, que a ligação de SLUG a região promotora de ZEB1 é dependente de uma outra proteína da família SNAIL, conhecida como SNAI1. A repressão de SNAI1, mas não de SLUG, resultou na desregulação de ZEB1 nessas células, sugerindo que a expressão de ZEB1 pode ser controlada por SNAI1, mas não por SLUG, em células de neoplasias mamárias (YE et al., 2015). Curiosamente, os níveis de expressão de ZEB2 foram significantemente diminuídos nas células CL-28E após a expressão exógena de SLUG. A diminuição desse FT, que antes apresentava alta expressão nessas células, pode ser considerada mais uma evidência do processo de EMT parcial. Lu e colaboradores demonstraram que há uma relação de "loop" entre a expressão de genes da família ZEB, o microRNA miR-200 e os três fenótipos envolvidos em EMT, sendo que o fenótipo 
híbrido ou parcial, está associado com a média expressão de miR-200 e ZEB, ao invés de alta expressão de ZEB (LU et al., 2013).

Desta maneira, nossos resultados sugerem que a maior formação de tumoresferas em cultivos de baixa aderência e a maior resistência a paclitaxel, características de uma população mais maligna de células, foi consequência do processo de EMT parcial, induzido pela expressão exógena de SLUG. Esses mesmos resultados são observados em neoplasias humanas, inclusive sugerindo que esse processo parcial está mais envolvido com o potencial tumorigênico e de auto-renovação das CITs do que o próprio processo completo de EMT (GROSSE-WILDE et al., 2015; RUSCETTI, 2015). Por fim, aqui foi demonstrado que os mecanismos responsáveis por uma possível obtenção do fenótipo de CITs, funcionam de maneira semelhante tanto em humanos, quanto em cães. O estudo dessa população de células utilizando o modelo canino apresenta um grande potencial futuro, devido ao pretexto das similaridades encontradas entre o desenvolvimento neoplásico em humanos e cães. Cabe aos pesquisadores responsáveis, o tracejo de investimentos e estratégias adequadas e lógicas para o avanço desses estudos, favorecendo tanto a oncologia veterinária, quanto a oncologia humana, em uma abordagem comparada e translacional. 


\section{CONCLUSÕES}

A partir dos resultados obtidos nesse estudo, é possível concluir que:

1. Em geral, há maior expressão de fatores de transcrição associados à EMT em células isoladas oriundas de amostras de carcinomas mamários caninos que apresentam fenótipo mesenquimal. Entretanto, somente a expressão desses genes não está associado ao potencial de invasão dessas células em modelos in vitro.

2. A expressão exógena de SLUG induziu o processo de transição epitéliomesenquimal parcial nas células oriundas de carcinomas mamários caninos, mimetizando parcialmente o fenótipo de CITs demonstrado pelo maior potencial tumorigênico avaliado pela formação de tumoresferas. 


\section{REFERÊNCIAS}

ADAMS, V. J. et al. Methods and mortality results of a health survey of purebred dogs in the UK. Journal of Small Animal Practice, v. 51, n. 10, p. 512-524, 2010.

AHMED, N. Molecular pathways regulating EGF-induced epithelio-mesenchymal transition in human ovarian surface epithelium. American Journal of ..., p. 1532 $1542,2006$.

AL-HAJJ, M. et al. Prospective identification of tumorigenic breast cancer cells. PNAS, v. 100, n. 11, p. 3983-3988, 2003.

AM ESCH, J. S. et al. Portal application of autologous CD133+ bone marrow cells to the liver: a novel concept to support hepatic regeneration. Stem cells, v. 23, n. 4, p. 463-470, 2005.

ANSIEAU, S.; COLLIN, G.; HILL, L. EMT or EMT-Promoting Transcription Factors, Where to Focus the Light? Frontiers in Oncology, v. 4, n. December, p. 1-4, 2014.

BAO, S. et al. Glioma stem cells promote radioresistance by preferential activation of the DNA damage response. Nature, v. 444, n. 7120, p. 756-760, 2006.

BECK, B.; BLANPAIN, C. Unravelling cancer stem cell potential. Nature Reviews Cancer, v. 13, n. 10, p. 727-738, 2013.

BENNETT, D. C. et al. A possible mammary stem cell line. Cell, v. 15, n. 1, p. $283-$ 298, 1978.

BERENBLUM, I.; SHUBIK, P. An experimental study of the initiating state of carcinogenesis, and a re-examination of the somatic cell mutation theory of cancer.

British journal of cancer, v. 3, n. 1, p. 109-18, 1949.

BHAT-NAKSHATRI, P. et al. SLUG/SNAI2 and tumor necrosis factor generate breast cells with CD44+/CD24- phenotype. BMC cancer, v. 10, p. 411, 2010.

BLACKING, T. M.; WATERFALL, M.; ARGYLE, D. J. CD44 is associated with proliferation, rather than a specific cancer stem cell population, in cultured canine cancer cells. Veterinary Immunology and Immunopathology, v. 141, n. 1-2, p. 4657, 2011.

BOLÓS, V. et al. The transcription factor Slug represses E-cadherin expression and induces epithelial to mesenchymal transitions: a comparison with Snail and E47 repressors. Journal of cell science, v. 116, n. Pt 3, p. 499-511, 2003.

BONNET, D.; DICK, J. E. Human acute myeloid leukemia is organized as a hierarchy that originates from a primitive hematopoietic cell. Nature medicine, v. 3, n. 7, p. 730737, 1997. 
BRABLETZ, T. et al. Invasion and metastasis in colorectal cancer: Epithelialmesenchymal transition, mesenchymal-epithelial transition, stem cells and $\beta$-catenin. Cells Tissues Organs, v. 179, n. 1-2, p. 56-65, 2005.

BRABLETZ, T. EMT and MET in Metastasis: Where Are the Cancer Stem Cells? Cancer Cell, v. 22, n. 6, p. 699-701, 2012.

BROOKS, M. D.; BURNESS, M. L.; WICHA, M. S. Therapeutic Implications of Cellular Heterogeneity and Plasticity in Breast Cancer. Cell Stem Cell, v. 17, n. 3, p. 260-271, 2015.

BURGER, H. et al. Brief report Imatinib mesylate ( STI571 ) is a substrate for the breast cancer resistance protein ( BCRP )/ ABCG2 drug pump. Blood, v. 104, n. 9, p. 2940-2942, 2004.

C??ME, C. et al. Snail and slug play distinct roles during breast carcinoma progression. Clinical Cancer Research, v. 12, n. 18, p. 5395-5402, 2006.

CAREW, R. M.; WANG, B.; KANTHARIDIS, P. The role of EMT in renal fibrosis. Cell and Tissue Research, v. 347, n. 1, p. 103-116, 2012.

CASSALI, G. D. et al. Evaluation of accuracy of fine needle aspiration cytology for diagnosis of canine mammary tumours: Comparative features with human tumours. Cytopathology, v. 18, n. 3, p. 191-196, 2007.

CHAFFER, C. L. et al. XPoised chromatin at the ZEB1 promoter enables breast cancer cell plasticity and enhances tumorigenicity. Cell, v. 154, n. 1, p. 61-74, 2013.

CHAPMAN, H. A. Epithelial-Mesenchymal Interactions in Pulmonary Fibrosis. Annual Review of Physiology, v. 73, n. 1, p. 413-435, 2011.

CHEN, J. et al. Induced Apoptosis in Ovarian Cancer Cells Through. p. 1722-1729, 2013.

CHEN, K.; HUANG, Y.; CHEN, J. Understanding and targeting cancer stem cells: therapeutic implications and challenges. Acta Pharmacologica Sinica, v. 34, n. 6, p. 732-740, 2013.

CHEN, Z. S. et al. Transport of methotrexate, methotrexate polyglutamates, and 17??estradiol 17-(??-D-glucuronide) by ABCG2: Effects of acquired mutations at R482 on methotrexate transport. Cancer Research, v. 63, n. 14, p. 4048-4054, 2003.

CHEUNG, A M. S. et al. Aldehyde dehydrogenase activity in leukemic blasts defines a subgroup of acute myeloid leukemia with adverse prognosis and superior NOD/SCID engrafting potential. Leukemia : official journal of the Leukemia Society of America, Leukemia Research Fund, U.K, v. 21, n. 7, p. 1423-1430, 2007.

Chikamatsu, 2013. , [s.d.]. 
CHIMGE, N.-O. et al. Regulation of Breast Cancer Metastasis by Runx2 and Estrogen Signaling: Role of SNAI2. Breast cancer research : BCR, v. 13, n. 6, p. R127, 2011.

CHUNG, S. S. et al. STAT3 activation in HER2-overexpressing breast cancer promotes epithelial-mesenchymal transition and cancer stem cell traits. International Journal of Oncology, v. 44, n. 2, p. 403-411, 2014.

COBALEDA, C. et al. Function of the zinc-finger transcription factor SNAI2 in cancer and development. Annual review of genetics, v. 41, p. 41-61, 2007.

COCOLA, C. et al. Isolation of canine mammary cells with stem cell properties and tumour-initiating potential. Reproduction in Domestic Animals, v. 44, n. SUPPL. 2, p. 214-217, 2009.

COLLINS, A. T. et al. Prospective identification of tumorigenic prostate cancer stem cells. Cancer Research, v. 65, n. 23, p. 10946-10951, 2005.

CORDEIRO, Y. G. Cultivo primário de células oriundas de carcinomas mamários de cadelas e caracterização de possíveis populações de células iniciadoras de tumor, 2015. Disponível em : http://www.teses.usp.br/teses/disponiveis/10/10133/tde-14102015143156/en.php

DEBEB, B. G.; WOODWARD, W. A. ALDH1 expression is enriched in breast cancers arising in young women but does not predict outcome. Breast Diseases, v. 25, n. 1, p. 47-48, 2014.

DIEN, J. et al. Signal transducers and activators of transcription-3 up-regulates tissue inhibitor of metalloproteinase-1 expression and decreases invasiveness of breast cancer. The American journal of pathology, v. 169, n. 2, p. 633-642, 2006.

ECKERT, M. A.; YANG, J. Targeting invadopodia to block breast cancer metastasis Abstract: v. 2, n. 7, p. 562-568, 2011.

ERAMO, A et al. Identification and expansion of the tumorigenic lung cancer stem cell population. Cell Death Differ, v. 15, n. 3, p. 504-514, 2008.

EROLES, P. et al. Molecular biology in breast cancer: Intrinsic subtypes and signaling pathways. Cancer Treatment Reviews, v. 38, n. 6, p. 698-707, 2012.

FELDMANN, G. et al. Blockade of hedgehog signaling inhibits pancreatic cancer invasion and metastases: A new paradigm for combination therapy in solid cancers. Cancer Research, v. 67, n. 5, p. 2187-2196, 2007.

FILLMORE, C. M.; KUPERWASSER, C. Human breast cancer cell lines contain stemlike cells that self-renew, give rise to phenotypically diverse progeny and survive chemotherapy. Breast cancer research : BCR, v. 10, n. 2, p. R25, 2008.

FREEDMAN, A. N. et al. Cancer risk prediction models: A workshop on development, evaluation, and application. Journal of the National Cancer Institute, v. 97, n. 10, p. 715-723, 2005. 
FUNAHASHI, J. et al. Delta-crystallin enhancer binding protein delta EF1 is a zinc finger-homeodomain protein implicated in postgastrulation embryogenesis.

Development (Cambridge, England), v. 119, n. 2, p. 433-446, 1993.

GAMBA, C. O. et al. ZEB2 and ZEB1 expression in a spontaneous canine model of invasive micropapillary carcinoma of the mammary gland. Research in Veterinary Science, v. 97, n. 3, p. 554-559, 2014.

GEMMILL, R. M. et al. ZEB1-responsive genes in non-small cell lung cancer. Cancer Letters, v. 300, n. 1, p. 66-78, 2011.

GERMAIN, A. R. et al. Identification of a selective small molecule inhibitor of breast cancer stem cells. Bioorganic and Medicinal Chemistry Letters, v. 22, n. 10, p. 3571-3574, 2012.

GINESTIER, C. et al. ALDH1 Is a Marker of Normal and Malignant Human Mammary Stem Cells and a Predictor of Poor Clinical Outcome. Cell Stem Cell, v. 1, n. 5, p. 555567, 2007.

GLOBOCAN. Estimated Incidence, Mortality and Prevalence Worldwide in 2012. Lyon: [s.n.]. 2012. Disponível em: <http://globocan.iarc.fr/Pages/fact_sheets_cancer.aspx>.

GOLDSCHMIDT, M. et al. Classification and grading of canine mammary tumors. Veterinary pathology, v. 48, n. 1, p. 117-131, 2011.

GOODELL, M. A et al. Isolation and functional properties of murine hematopoietic stem cells that are replicating in vivo. The Journal of experimental medicine, v. 183, n. 4, p. 1797-806, 1996.

GRÉEN, H. et al. mdr-1 single nucleotide polymorphisms in ovarian cancer tissue: G2677T/A correlates with response to paclitaxel chemotherapy. Clinical Cancer Research, v. 12, n. 3 I, p. 854-859, 2006.

GRIMES, H. L. et al. The Gfi-1 proto-oncoprotein contains a novel transcriptional repressor domain, SNAG, and inhibits G1 arrest induced by interleukin-2 withdrawal. Molecular and cellular biology, v. 16, n. 11, p. 6263-72, 1996.

GROSSE-WILDE, A. et al. Stemness of the hybrid epithelial/mesenchymal state in breast cancer and its association with poor survival. PLoS ONE, v. 10, n. 5, p. 1-28, 2015.

GUAITA, S. et al. Snail induction of epithelial to mesenchymal transition in tumor cells is accompanied by MUC1 repression and ZEB1 expression. Journal of Biological Chemistry, v. 277, n. 42, p. 39209-39216, 2002.

GUO, W. et al. Slug and Sox9 Cooperatively Determine the Mammary Stem Cell State. p. 1015-1028, 2012. 
GUPTA, K.; SOOD, N.; UPPAL, S. Epidemiological studies on canine mammary tumour and its relevance for breast cancer studies. IOSR Journal of Pharmacy, v. 2, n. 2, p. 322-333, 2012.

GUPTA, P. B. et al. Identification of selective inhibitors of cancer stem cells by highthroughput screening. Cell, v. 138, n. 4, p. 645-59, 2009.

HAGER, J. C. et al. Characterization of a variant-producing tumor cell line from a heterogeneous strain BALB/cfC3H mouse mammary tumor. Cancer Res, v. 41, n. 4, p. 1293-1300, 1981.

HAJRA, K. M.; CHEN, D. Y.; FEARON, E. R. The SLUG Zinc-Finger Protein Represses E-Cadherin in Breast Cancer Advances in Brief The SLUG Zinc-Finger Protein Represses E-Cadherin in Breast Cancer 1. n. 734, p. 1613-1618, 2002.

HAMPE, J. F.; MISDORP, W. Tumours and dysplasias of the mammary gland. Bulletin of the World Health Organization, v. 50, n. 1-2, p. 111-133, 1974.

HANAHAN, D.; WEINBERG, R. A; FRANCISCO, S. The Hallmarks of Cancer Review University of California at San Francisco. Cell Press, v. 100, n. 7, p. 57-70, 2000.

HANAHAN, D.; WEINBERG, R. A. Hallmarks of cancer: The next generation. Cell, v. 144, n. 5, p. 646-674, 2011.

HASLEHURST, A. M. et al. EMT transcription factors snail and slug directly contribute to cisplatin resistance in ovarian cancer. BMC Cancer, v. 12, n. 1, p. 91, 2012.

HEISENBERG, C. P.; SOLNICA-KREZEL, L. Back and forth between cell fate specification and movement during vertebrate gastrulation. Current Opinion in Genetics and Development, v. 18, n. 4, p. 311-316, 2008.

HEMAVATHY, K.; ASHRAF, S. I.; IP, Y. T. Snail/Slug family of repressors: Slowly going into the fast lane of development and cancer. Gene, v. 257, n. 1, p. 1-12, 2000.

HERMANN, P. C. et al. Distinct Populations of Cancer Stem Cells Determine Tumor Growth and Metastatic Activity in Human Pancreatic Cancer. Cell Stem Cell, v. 1, n. 3, p. 313-323, 2007.

HIRSCHMANN-JAX, C. et al. A distinct "side population" of cells with high drug efflux capacity in human tumor cells. Proceedings of the National Academy of Sciences of the United States of America, v. 101, n. 39, p. 14228-33, 2004.

HO, D. W. Y. et al. Gene Expression Profiling of Liver Cancer Stem Cells by RNASequencing. PLoS ONE, v. 7, n. 5, p. e37159, 2012.

HOLYOAKE, T. et al. Isolation of a highly quiescent subpopulation of primitive leukemic cells in chronic myeloid leukemia. Blood, v. 94, n. 6, p. 2056-2064, 1999. 
HUANG, E. H. et al. NIH Public Access. v. 69, n. 8, p. 3382-3389, 2010.

HUBER, M. A.; KRAUT, N.; BEUG, H. Molecular requirements for epithelialmesenchymal transition during tumor progression. Current Opinion in Cell Biology, v. 17, n. 5 SPEC. ISS., p. 548-558, 2005.

HUGO, H. J. et al. Direct repression of MYB by ZEB1 suppresses proliferation and epithelial gene expression during epithelial-to-mesenchymal transition of breast cancer cells. Breast cancer research : BCR, v. 15, n. 6, p. R113, 2013.

ILIOPOULOS, D. et al. Loss of miR-200 Inhibition of Suz12 Leads to PolycombMediated Repression Required for the Formation and Maintenance of Cancer Stem Cells. Molecular Cell, v. 39, n. 5, p. 761-772, 2010.

INCA. Estimativa 2014: incidência de câncer no Brasil. Rio de Janeiro: Instituto Nacional do Câncer, 2014.

INUKAI, T. et al. SLUG, a ces-1-related zinc finger transcription factor gene with antiapoptotic activity, is a downstream target of the E2A-HLF oncoprotein. Molecular Cell, v. 4, n. 3, p. 343-352, 1999.

IŞERI, O. D. et al. Drug resistant MCF-7 cells exhibit epithelial-mesenchymal transition gene expression pattern. Biomedicine \& pharmacotherapy = Biomédecine \& pharmacothérapie, v. 65, n. 1, p. 40-5, 2011.

JACOB, A.; PREKERIS, R. The regulation of MMP targeting to invadopodia during cancer metastasis. Frontiers in cell and developmental biology, v. 3, n. February, p. 4, 2015.

JIN, L. et al. Monoclonal Antibody-Mediated Targeting of CD123, IL-3 Receptor ?? Chain, Eliminates Human Acute Myeloid Leukemic Stem Cells. Cell Stem Cell, v. 5, n. 1, p. 31-42, 2009.

JOLLY, M. K. Implications of the Hybrid Epithelial/Mesenchymal Phenotype in Metastasis. Frontiers in Oncology, v. 5, n. July, p. 1-19, 2015.

KALLURI, R.; WEINBERG, R. A. Review series The basics of epithelialmesenchymal transition. Journal of Clinical Investigation, v. 119, n. 6, p. 1420-1428, 2009.

KHANNA, C.; ROSENBERG, M.; VAIL, D. M. A review of paclitaxel and novel formulations including those suitable for use in dogs. Journal of Veterinary Internal Medicine, v. 29, n. 4, p. 1006-1012, 2015.

KLOPFLEISCH, R. et al. HEPACAM1 and 2 are differentially regulated in canine mammary adenomas and carcinomas and its lymph node metastases. BMC veterinary research, v. 6, p. 15, 2010.

KLOPFLEISCH, R.; SCH??TZE, M.; GRUBER, A. D. Downregulation of transforming growth factor ?? (TGF??) and latent TGF?? binding protein (LTBP)-4 
expression in late stage canine mammary tumours. Veterinary Journal, v. 186, n. 3, p. 379-384, 2010.

KORKAYA, H. et al. Regulation of mammary stem/progenitor cells by PTEN/Akt/??catenin signaling. PLoS Biology, v. 7, n. 6, 2009.

KRENNING, G.; ZEISBERG, E. M.; KALLURI, R. The origin of fibroblast and mechanism of cardiac fibrosis. Journal of cell physiology, v. 225, n. 3, p. 631-637, 2010 .

KRESO, A et al. Variable clonal repopulation dynamics influence chemotherapy response in colorectal cancer. Science, v. 339, n. 6119, p. 543-548, 2013.

KRESO, A.; DICK, J. E. Evolution of the Cancer Stem Cell Model. Cell Stem Cell, v. 14, n. 3, p. 275-291, 2014.

LAI, R. et al. Signal transducer and activator of transcription-3 activation contributes to high tissue inhibitor of metalloproteinase-1 expression in anaplastic lymphoma kinasepositive anaplastic large cell lymphoma. Am J Pathol, v. 164, n. 6, p. 2251-2258, 2004.

LAMBERTINI, E. et al. Correlation between Slug transcription factor and miR-221 in MDA-MB-231 breast cancer cells. BMC Cancer, v. 12, n. 1, p. 445, 2012.

LAMOUILLE, S.; XU, J.; DERYNCK, R. Molecular mechanisms of epithelialmesenchymal transition. Nature Reviews Molecular Cell Biology, v. 15, n. 3, p. 178196, 2014.

LAPIDOT, T. et al. A cell initiating human acute myeloid leukaemia after transplantation into SCID mice. Nature, v. 367, n. 6464, p. 645-648, 1994.

LEHMANN, W. et al. ZEB1 turns into a transcriptional activator by interacting with YAP1 in aggressive cancer types. Nat Commun, v. 7, p. 1-15, 2016.

LEROY, P. MOSTOV, K. E. Slug Is Required for Cell Survival during Partial Epithelial-Mesenchymal Transition of HGF-induced Tubulogenesis. Molecular Biology of the Cell, v. 18, p. 1943-1952, 2007.

LI, A. et al. Fascin is regulated by slug, promotes progression of pancreatic cancer in mice, and is associated with patient outcomes. Gastroenterology, v. 146, n. 5, p. 13861396.e17, 2014.

LI, C. et al. Identification of pancreatic cancer stem cells. Cancer Research, v. 67, n. 3, p. 1030-1037, 2007.

LI, C. I.; URIBE, D. J.; DALING, J. R. Clinical characteristics of different histologic types of breast cancer. British journal of cancer, v. 93, n. 9, p. 1046-52, 2005. 
LIM, E. et al. Aberrant luminal progenitors as the candidate target population for basal tumor development in BRCA1 mutation carriers. Nature medicine, v. 15, n. 8, p. 90713, 2009.

LINDBLAD-TOH, K. et al. Genome sequence, comparative analysis and haplotype structure of the domestic dog. Nature, v. 438, n. 7069, p. 803-819, 2005.

LISKOVA, P. et al. Novel mutations in the ZEB1 gene identified in Czech and British patients with posterior polymorphous corneal dystrophy. Human mutation, v. 28, n. 6 , p. 638, 2007.

LIVAK, K. J.; SCHMITTGEN, T. D. Analysis of relative gene expression data using real-time quantitative PCR and the $2^{\wedge}(-\Delta \Delta \mathrm{CT})$ method. Methods (San Diego, Calif.), v. 25, n. 4, p. 402-408, 2001.

LU, M. et al. Mesenchymal Fate Determination. 2013.

MACHESKY, L. M. Lamellipodia and filopodia in metastasis and invasion. FEBS Letters, v. 582, n. 14, p. 2102-2111, 2008.

MACHIELA, M. J.; CHANOCK, S. J. GWAS is going to the dogs. Genome Biology, v. 15, n. 3, p. 105, 2014.

MANI, S. A. et al. The Epithelial-Mesenchymal Transition Generates Cells with Properties of Stem Cells. Cell, v. 133, n. 4, p. 704-715, 2008.

MAUHIN, V. et al. Definition of the DNA-binding site repertoire for the Drosophila transcription factor SNAIL. Nucleic Acids Research, v. 21, n. 17, p. 3951-3957, 1993.

MCFADDEN, B.; HEITZMAN-POWELL, L. HHS Public Access. v. 8, n. 12, p. 1699 $1712,2015$.

MCGOWAN, P. M. et al. Notch1 inhibition alters the CD44hi/CD24lo population and reduces the formation of brain metastases from breast cancer. Molecular cancer research : MCR, v. 9, n. 7, p. 834-44, 2011.

MCGRANAHAN, N.; SWANTON, C. Biological and Therapeutic Impact of Intratumor Heterogeneity in Cancer Evolution. Cancer Cell, v. 27, n. 1, p. 15-26, 2015.

MICHISHITA, M. et al. Characterization of spheres derived from canine mammary gland adenocarcinoma cell lines. Research in Veterinary Science, v. 91, n. 2, p. 254260, 2011.

MICHISHITA, M. et al. Aldehyde dehydrogenase activity in cancer stem cells from canine mammary carcinoma cell lines. Veterinary journal (London, England : 1997), v. 193, n. 2, p. 508-13, 2012. 
MISDORP et al. Histological Classification of Mammary Tumors of the Dog and the Cat. Armed Forces Institute of Pathology and the American Registry of Pathology and The World Health Organization Collaborating Center for Worldwide Reference on Comparative Oncology, Washington, D.C., USA, vol. 7, p. 11-29, 1999.

MITTAL, M. K. et al. In vivo binding to and functional repression of the VDR gene promoter by SLUG in human breast cells. Biochemical and Biophysical Research Communications, v. 372, n. 1, p. 30-34, 2008.

MOREL, A.-P. et al. Generation of breast cancer stem cells through epithelialmesenchymal transition. PloS one, v. 3, n. 8, p. e2888, 2008.

NEELAKANTAN, D.; DRASIN, D. J.; FORD, H. L. Intratumoral heterogeneity: Clonal cooperation in epithelial-to-mesenchymal transition and metastasis. Cell adhesion \& migration, v. 9, n. 4, p. 265-76, 2015.

NIBU, Y. et al. dCtBP mediates transcriptional repression by Knirps, Krüppel and Snail in the Drosophila embryo. The EMBO journal, v. 17, n. 23, p. 7009-7020, 1998.

NIETO, M. A. the Snail Superfamily of Zinc-. Cell, v. 3, n. March, 2002.

NJIAJU, U. O.; OLOPADE, O. I. Genetic determinants of breast cancer risk: a review of current literature and issues pertaining to clinical application. Breast J, v. 18, n. 5, p. 436-42, 2012.

PALMA-NICOLÀS, J. P.; LÓPEZ-COLOM??, A. M. Thrombin induces slug-mediated E-cadherin transcriptional repression and the parallel Up-regulation of $\mathrm{N}$-cadherin by a transcription-independent mechanism in RPE cells. Journal of Cellular Physiology, v. 228, n. 3, p. 581-589, 2013.

PAOLONI, M.; KHANNA, C. Translation of new cancer treatments from pet dogs to humans. Nature reviews. Cancer, v. 8, n. 2, p. 147-156, 2008.

PATTABIRAMAN, D. R.; WEINBERG, R. A. Tackling the cancer stem cells - what challenges do they pose? Nature reviews. Drug discovery, v. 13, n. 7, p. 497-512, 2014.

PECE, S. et al. Biological and Molecular Heterogeneity of Breast Cancers Correlates with Their Cancer Stem Cell Content. Cell, v. 140, n. 1, p. 62-73, 2010.

PÉREZ-LOSADA, J. et al. Zinc-finger transcription factor Slug contributes to the function of the stem cell factor c-kit signaling pathway. Blood, v. 100, n. 4, p. 12741286, 2002.

PHILLIPS, S.; KUPERWASSER, C. SLUG: Critical regulator of epithelial cell identity in breast development and cancer http://www.tandfonline.com/doi/pdf/10.4161/19336918.2014.972740. Cell Adhesion and Migration, v. 8, n. 6, p. 578-587, 2014. 
POLYAK, K.; WEINBERG, R. A. Transitions between epithelial and mesenchymal states: acquisition of malignant and stem cell traits. Nature reviews. Cancer, v. 9, n. 4, p. $265-73,2009$.

POSTIGO, A. A. et al. Regulation of Smad signaling through a differential recruitment of coactivators and corepressors by ZEB proteins. EMBO Journal, v. 22, n. 10, p. 2453-2462, 2003.

QI, S. et al. ZEB2 mediates multiple pathways regulating cell proliferation, migration, invasion, and apoptosis in glioma. PLoS ONE, v. 7, n. 6, p. 1-12, 2012.

RAO, N. A S. et al. cDNA microarray profiles of canine mammary tumour cell lines reveal deregulated pathways pertaining to their phenotype. Animal Genetics, v. 39, n. 4, p. 333-345, 2008.

RICHARDSON, G. D. et al. CD133, a novel marker for human prostatic epithelial stem cells. Journal of Cell Science, v. 117, n. 16, p. 3539-3545, 2004.

RIVERA, P. J. et al. Mammary tumor development in dogs is associated with BRCA1 and BRCA2. Cancer Research, v. 69, n. 22, p. 8770-8774, 2009.

ROESCH, A. et al. A Temporarily Distinct Subpopulation of Slow-Cycling Melanoma Cells Is Required for Continuous Tumor Growth. Cell, v. 141, n. 4, p. 583-594, 2010.

ROULOIS, D. et al. DNA-Demethylating Agents Target Colorectal Cancer Cells by Inducing Viral Mimicry by Endogenous Transcripts Article DNA-Demethylating Agents Target Colorectal Cancer Cells by Inducing Viral Mimicry by Endogenous Transcripts. Cell, v. 162, n. 5, p. 961-973, 2015.

RUNGSIPIPAT, A et al. Immunohistochemical analysis of c-yes and c-erbB-2 oncogene products and p53 tumor suppressor protein in canine mammary tumors. The Journal of veterinary medical science / the Japanese Society of Veterinary Science, v. 61, n. 1, p. $27-32,1999$.

SAEKI, T. et al. Dofequidar fumarate (MS-209) in combination with cyclophosphamide, doxorubicin, and fluorouracil for patients with advanced or recurrent breast cancer. Journal of Clinical Oncology, v. 25, n. 4, p. 411-417, 2007.

SALVADOR, M. A. et al. The histone deacetylase inhibitor abexinostat induces Cancer stem cells differentiation in breast Cancer with low Xist expression. Clinical Cancer Research, v. 19, n. 23, p. 6520-6531, 2013.

SÁNCHEZ-MARTÍN, M. et al. SLUG (SNAI2) deletions in patients with Waardenburg disease. Human molecular genetics, v. 11, n. 25, p. 3231-3236, 2002.

SÁNCHEZ-TILLÓ, E. et al. ZEB1 represses E-cadherin and induces an EMT by recruiting the SWI/SNF chromatin-remodeling protein BRG1. Oncogene, v. 29, n. 24, p. 3490-3500, 2010. 
SARRI??, D. et al. Epithelial-mesenchymal transition in breast cancer relates to the basal-like phenotype. Cancer Research, v. 68, n. 4, p. 989-997, 2008.

SAUKA-SPENGLER, T.; BRONNER-FRASER, M. A gene regulatory network orchestrates neural crest formation. Nature reviews. Molecular cell biology, v. 9, n. 7, p. 557-68, 2008 .

SAVAGNER, P. et al. Developmental transcription factor slug is required for effective re-epithelialization by adult keratinocytes. Journal of Cellular Physiology, v. 202, n. 3 , p. 858-866, 2005.

SCHNITT, S. J. Classification and prognosis of invasive breast cancer: from morphology to molecular taxonomy. Modern pathology : an official journal of the United States and Canadian Academy of Pathology, Inc, v. 23 Suppl 2, n. S2, p. S60-S64, 2010.

SHIH, J. Y.; YANG, P. C. The EMT regulator slug and lung carcinogenesis. Carcinogenesis, v. 32, n. 9, p. 1299-1304, 2011.

SHIMODA, M. et al. The T-box transcription factor Brachyury regulates epithelial ¿mesenchymal transition in association with cancer stem-like cells in adenoid cystic carcinoma cells. BMC Cancer, v. 12, n. 1, p. 377, 2012.

SINGH, S. K. et al. Identification of a cancer stem cell in human brain tumors. Cancer Res., v. 63, n. 18, p. 5821-5828, 2003.

SKVORTSOVA, I. et al. Radiation resistance: Cancer stem cells (CSCs) and their enigmatic pro-survival signaling. Seminars in Cancer Biology, v. 35, p. 39-44, 2015.

SMALLEY, M.; PIGGOTT, L.; CLARKSON, R. Breast cancer stem cells: Obstacles to therapy. Cancer Letters, v. 338, n. 1, p. 57-62, 2013.

SONG, S. J. et al. MicroRNA-Antagonism Regulates Breast Cancer Stemness and Metastasis via TET-Family-Dependent Chromatin Remodeling. Cell, v. 154, n. 2, p. 311-324, 2013.

song, 2013. , [s.d.].

SPARREBOOM, A. et al. Effect of ABCG2 genotype on the oral bioavailability of topotecan. Cancer biology \& therapy., v. 4, n. 6, p. 650-658, 2005.

STEPHENS, P. J. et al. The landscape of cancer genes and mutational processes in breast cancer. Nature, v. 486, n. 7403, p. 400-4, 2012.

TAKAHASHI, R. et al. Loss of microRNA-27b contributes to breast cancer stem cell generation by activating ENPP1. Nature Communications, v. 6, p. 7318, 2015.

TAMURA, D. et al. Slug increases sensitivity to tubulin-binding agents via the downregulation of $\beta I I I$ and $\beta I V a-t u b u l i n$ in lung cancer cells. Cancer medicine, v. $2, \mathrm{n}$. 2, p. 144-54, 2013. 
TELL, R. W.; HORVATH, C. M. Bioinformatic analysis reveals a pattern of STAT3associated gene expression specific to basal-like breast cancers in human tumors.

Proceedings of the National Academy of Sciences of the United States of America, v. 111, n. 35, p. 1-6, 2014.

THIERY, J. P. Epithelial-mesenchymal transitions in tumour progression. Nature reviews. Cancer, v. 2, n. 6, p. 442-454, 2002.

THIERY, J. P. et al. Epithelial-Mesenchymal Transitions in Development and Disease. Cell, v. 139, n. 5, p. 871-890, 2009.

TRIPATHI, M. K. et al. Regulation of BRCA2 gene expression by the SLUG repressor protein in human breast cells. Journal of Biological Chemistry, v. 280, n. 17, p. 17163-17171, 2005.

TSAI, H. C. et al. Transient Low Doses of DNA-Demethylating Agents Exert Durable Antitumor Effects on Hematological and Epithelial Tumor Cells. Cancer Cell, v. 21, n. 3, p. 430-446, 2012.

ULASOV, I.; NANDI, S. <Title/>. Molecular Medicine, v. 17, n. 1-2, p. 1, 2011.

UVA, P. et al. Comparative expression pathway analysis of human and canine mammary tumors. BMC genomics, v. 10, p. 135, 2009.

UYGUR, B.; WU, W.-S. SLUG promotes prostate cancer cell migration and invasion via CXCR4/CXCL12 axis. Molecular cancer, v. 10, n. 1, p. 139, 2011.

VAIOPOULOS, A. G. et al. Concise review: Colorectal cancer stem cells. Stem Cells, v. 30, n. 3, p. 363-371, 2012.

VALASTYAN, S.; WEINBERG, R. A. Tumor metastasis: Molecular insights and evolving paradigms. Cell, v. 147, n. 2, p. 275-292, 2011.

VALLONE, P. M.; BUTLER, J. M. AutoDimer: A screening tool for primer-dimer and hairpin structures. BioTechniques, v. 37, n. 2, p. 226-231, 2004.

VANDEWALLE, C.; VAN ROY, F.; BERX, G. The role of the ZEB family of transcription factors in development and disease. Cellular and Molecular Life Sciences, v. 66, n. 5, p. 773-787, 2009.

VERMEULEN, L. et al. Wnt activity defines colon cancer stem cells and is regulated by the microenvironment. Nature Cell Biology, v. 12, n. 5, p. 468-476, 2010.

VESUNA, F. et al. Twist modulates breast cancer stem cells by transcriptional regulation of CD24 expression. Neoplasia (New York, N.Y.), v. 11, n. 12, p. 1318-28, 2009.

VITALI, R. et al. Slug (SNAI2) down-regulation by interference facilitates apoptosis and inhibits invasive growth in neuroblastoma preclinical models. Clinical Cancer Research, v. 14, n. 14, p. 4622-4630, 2008. 
VUORILUOTO, K. et al. Vimentin regulates EMT induction by Slug and oncogenic $\mathrm{H}-$ Ras and migration by governing Axl expression in breast cancer. Oncogene, v. 30, $\mathrm{n}$. 12, p. 1436-48, 2011.

WANG, C. H. et al. Photothermolysis of glioblastoma stem-like cells targeted by carbon nanotubes conjugated with CD133 monoclonal antibody. Nanomedicine: Nanotechnology, Biology, and Medicine, v. 7, n. 1, p. 69-79, 2011.

WANG, F.-P. et al. Reversal of P-glycoprotein-dependent resistance to vinblastine by newly synthesized bisbenzylisoquinoline alkaloids in mouse leukemia P388 cells. Biological \& pharmaceutical bulletin, v. 28, n. 10, p. 1979-82, 2005.

WANG, J. et al. Overexpression of miR-200a suppresses epithelial-mesenchymal transition of liver cancer stem cells. Tumour biology : the journal of the International Society for Oncodevelopmental Biology and Medicine, v. 36, n. 4, p. 2447-2456, 2015.

WANG, S.-P. et al. p53 controls cancer cell invasion by inducing the MDM2-mediated degradation of Slug. Nature cell biology, v. 11, n. 6, p. 694-704, 2009a.

WANG, Z. et al. Acquisition of epithelial-mesenchymal transition phenotype of gemcitabine-resistant pancreatic cancer cells is linked with activation of the notch signaling pathway. Cancer Research, v. 69, n. 6, p. 2400-2407, 2009b.

WELCH-REARDON, K. M. et al. Angiogenic sprouting is regulated by endothelial cell expression of Slug. Journal of cell science, v. 127, n. Pt 9, p. 2017-28, 2014.

WELLNER, U. et al. The EMT-activator ZEB1 promotes tumorigenicity by repressing stemness-inhibiting microRNAs. Nature cell biology, v. 11, n. 12, p. 1487-1495, 2009.

WENDT, M. K. et al. STAT3 and epithelial-mesenchymal transitions in carcinomas. Jak-Stat, v. 3, n. 1, p. e28975, 2014.

WILSON, H. et al. Isolation and characterisation of cancer stem cells from canine osteosarcoma. Veterinary Journal, v. 175, n. 1, p. 69-75, 2008.

XIE, T.-X. et al. Stat 3 activation regulates the expression of matrix metalloproteinase-2 and tumor invasion and metastasis. Oncogene, v. 23, n. 20, p. 3550-60, 2004.

YAN, C. et al. Epithelial to mesenchymal transition in human skin wound healing is induced by tumor necrosis factor-alpha through bone morphogenic protein-2. The American journal of pathology, v. 176, n. 5, p. 2247-58, 2010.

YE, J. et al. Primer-BLAST: A tool to design target-specific primers for polymerase chain reaction. BMC Bioinformatics, v. 13, n. 1, p. 134, 2012.

YE, X. et al. Distinct EMT programs control normal mammary stem cells and tumourinitiating cells. Nature, v. 525, p. 256-260, 2015. 
ZARDAVAS, D. et al. Clinical management of breast cancer heterogeneity. Nature reviews. Clinical oncology, v. 12, n. 7, p. 1-14, 2015.

ZHANG, G.-J. et al. High expression of ZEB1 correlates with liver metastasis and poor prognosis in colorectal cancer. Oncology letters, v. 5, n. 2, p. 564-568, 2013.

ZHANG, P.; SUN, Y.; MA, L. ZEB1: At the crossroads of epithelial-mesenchymal transition, metastasis and therapy resistance. Cell Cycle, v. 14, n. 4, p. 481-487, 2015.

ZHANG, S. et al. Identification and characterization of ovarian cancer-initiating cells from primary human tumors. Cancer research, v. 68, n. 11, p. 4311-20, 2008.

ZHOU, S. et al. The ABC transporter Bcrp1/ABCG2 is expressed in a wide variety of stem cells and is a molecular determinant of the side-population phenotype. Nature medicine, v. 7, n. 9, p. 1028-1034, 2001.

ZHU, L.-F. et al. Snail overexpression induces an epithelial to mesenchymal transition and cancer stem cell-like properties in SCC9 cells. Laboratory Investigation, v. 92, n. 5, p. 744-752, 2012. 